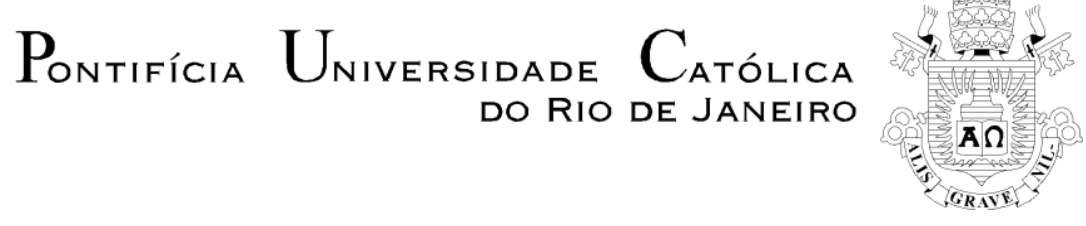

Ana Tereza Pinto de Sequeiros Correia

DESIGN E AS TECNOLOGIAS CONTEMPORÂNEAS NA CRIAÇÃO DE NARRATIVAS DIGITAIS PARA CRIANÇAS SURDAS E OUVINTES

Tese de Doutorado

Tese apresentada ao Programa de Pósgraduação em Design da PUC-Rio como Requisito parcial para obtenção do grau de Doutor em Design.

Orientadora: Profa Rita Maria de Souza Couto

Co-orientadora: Profa Cristina Portugal 


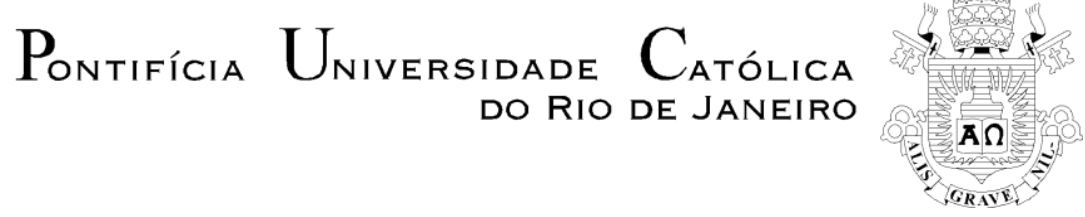

Ana Tereza Pinto de Sequeiros Correia

\section{DESIGN E AS TECNOLOGIAS CONTEMPORÂNEAS NA CRIAÇÃO DE NARRATIVAS DIGITAIS PARA CRIANÇAS SURDAS E OUVINTES}

Tese apresentada como requisito parcial para obtenção do grau de Doutor pelo Programa de Pós-Graduação em Design do Departamento de Artes \& Design da PUC-Rio. Aprovada pela Comissão Examinadora abaixo assinada.

Profa. Rita Maria de Souza Couto

Orientadora

Departamento de Artes \& Design - PUC-Rio

Profa. Cristina Portugal

Co-orientadora

Departamento de Artes \& Design - PUC-Rio

Profa. Luiza Novaes

Departamento de Artes \& Design - PUC-Rio

Prof-. Bianca Maria Rego Martins

Departamento de Artes \& Design - PUC-Rio

Prof. Daniel Wyllie Lacerda Rodrigues

Membro externo - UFRJ - EBA

Prof. Gabriel Filipe Santiago Cruz Membro externo - UVA

Prof ${ }^{\mathrm{a}}$ Monah Winograd

Coordenadora Setorial do Centro de Teologia e Ciências Humanas - PUC-Rio

Rio de Janeiro, 14 de setembro de 2018 
Todos os direitos reservados. É proibida a reprodução total ou parcial do trabalho sem autorização do autor, do orientador e da universidade.

\section{Ana Tereza Pinto de Sequeiros Correia}

Graduou-se em Desenho Industrial / Comunicação Visual na PUCRio (Pontifícia Universidade Católica do Rio de Janeiro), em 2007. Especializou-se em Web Design pelo CCE - PUC-Rio, em 2009. Criou Fábulas para Crianças Surdas, que tem por finalidade auxiliar na aquisição da linguagem por crianças surdas, em 2007. Participou do SILID e SIMAR na PUC-Rio com este projeto. Adquiriu o grau de Mestre em Design pela PUC-Rio, em 2012. Faz parte do LIDE (Laboratório Interdisciplinar de Design e Educação) na PUC-Rio e é doutoranda do Programa de Pós-graduação em Design do Departamento de Artes \& Design da PUC-Rio.

Ficha Catalográfica

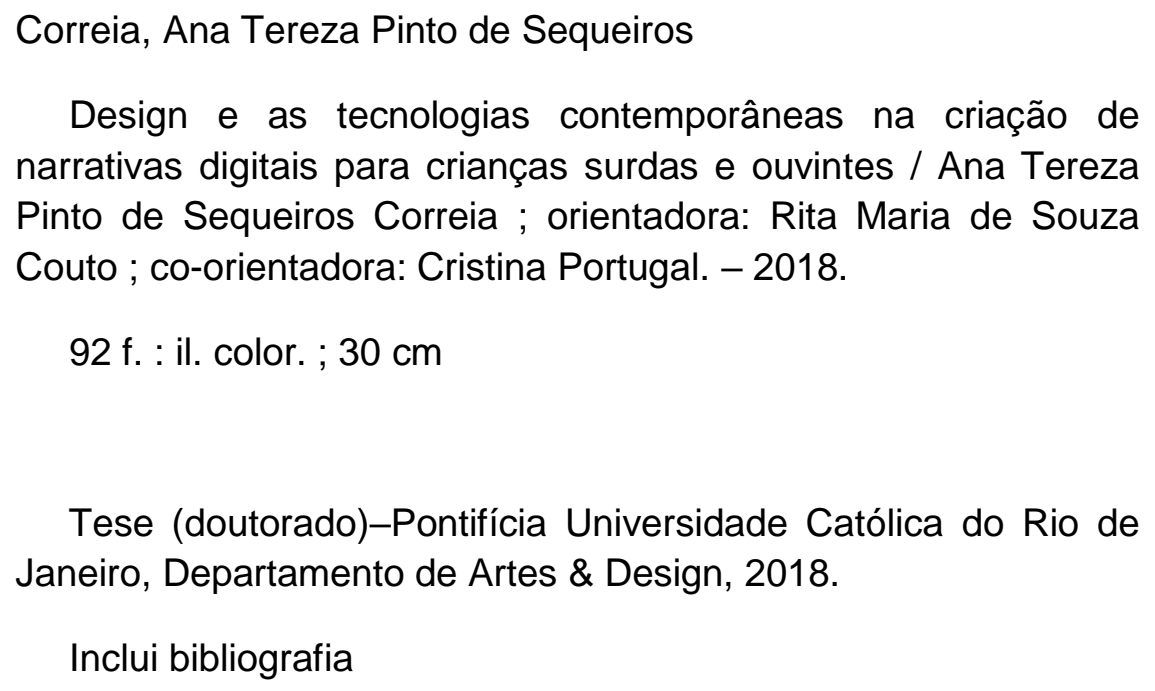
narrativas digitais para crianças surdas e ouvintes / Ana Tereza Pinto de Sequeiros Correia ; orientadora: Rita Maria de Souza Couto ; co-orientadora: Cristina Portugal. - 2018.

92 f. : il. color. ; $30 \mathrm{~cm}$

Tese (doutorado)-Pontifícia Universidade Católica do Rio de Janeiro, Departamento de Artes \& Design, 2018.

Inclui bibliografia

1. Artes \& Design - Teses. 2. Livro digital. 3. História interativa. 4. Crianças surdas. 5. Construção de narrativa digital interativa bilíngue. 6. LIBRAS. I. Couto, Rita Maria de Souza. II. Portugal, Cristina. III. Pontifícia Universidade Católica do Rio de Janeiro. Departamento de Artes \& Design. IV. Título. 
Tu te tornas eternamente responsável por aquilo que cativas. Antoine de Saint-Exupéry 


\section{Agradecimentos}

A Deus e à minha família por me guiarem pelo caminho percorrido até aqui.

À minha mãe, por sua determinação e doçura. Por ser o maior exemplo de uma mulher independente, que nunca abriu mão de ser uma mãe zelosa e presente, colocando sempre a mim e a minha irmã em primeiro lugar em sua vida.

Ao meu pai, pelo apoio às minhas escolhas por cada dia de trabalho, proporcionando-nos nossa maior herança e o que ele sempre julgou ser o mais importante: o conhecimento. Agradeço também por cada lágrima de felicidade por minhas conquistas.

À minha irmã, companheira desde seu nascimento. Melhor amiga, confidente e parceira em todos os dias de nosso crescimento, incondicionalmente, sempre ao meu lado.

Aos meus avós por me acompanharem com o mesmo empenho e dedicação de meus pais, sempre compartilhando sua sabedoria e doçura.

Ao Paulo Vitor Cappelli, por toda sua compreensão, carinho e amor.

À minha orientadora Prof. Dra. Rita Maria de Souza Couto, por ter acreditado em meu potencial desde que ingressei no grupo de pesquisas do LIDE e por todos os momentos onde suas doces palavras me motivaram a seguir adiante.

À minha co-orientadora Prof. Dra. Cristina Portugal, por compartilhar seu companheirismo e atenção e por contribuir sempre de forma tão rica.

Além de minha orientadora e co-orientadora, aos membros de minha equipe no LIDE, Eliane Jordy e aos colaboradores Natália Brunnet e Lucas Ribeiro.

À banca de qualificação e a da defesa da tese, que colaboraram consideravelmente para questões referentes à conclusão desta pesquisa.

À PUC por disponibilizar a bolsa VRAC para o curso de pós-graduação em Design. 


\section{Resumo}

Correia, Ana Tereza Pinto de Sequeiros; Couto, Rita Maria de Souza Portugal, Cristina. Design e as tecnologias contemporâneas na criação de narrativas digitais para crianças surdas e ouvintes. Rio de Janeiro, 2018. 92p. Tese de Doutorado - Departamento de Artes \& Design, Pontifícia Universidade Católica do Rio de Janeiro.

A presente tese tem por objetivo geral fornecer à luz de metodologias de Design em Situações de Ensino-Aprendizagem, o uso de recursos inclusivos para o desenvolvimento de narrativas digitais bilíngues para crianças surdas, de forma participativa. Aborda questões históricas acerca do oralismo e gestualismo, como a aquisição da linguagem na mais tenra idade é fundamental para o desenvolvimento cognitivo infantil e as dificuldades encontradas no ensino simultâneo da Língua Brasileira de Sinais, a LIBRAS e do português escrito. Apresenta uma reflexão sobre como a tecnologia pode ser usada como mediadora para a aprendizagem de conteúdos socioculturais, assim como o desenvolvimento de habilidades sensóriomotoras e cognitivas no processo de crescimento da criança. Desenvolve-se como um estudo de caso com a criação de uma história interativa digital bilíngue, concebida e desenvolvida pela equipe do Laboratório Interdisciplinar Design/Educação, do Departamento de Artes \& Design, da PUC-Rio (LIDE | DAD | PUC-Rio ), contemplada pela Chamada Universal 14/2013 - CNPq, que tem as etapas para a sua construção descritas. Ao final, disponibiliza orientações para a construção de narrativas interativas digitais com os objetivos acima descritos, a fim de fomentar o campo do Design em Parceria com a Educação, ampliando o alcance de projetos desta natureza para este público.

\section{Palavras-chave}

Livro digital; História interativa; Crianças surdas; Construção de narrativa digital interativa bilíngue; LIBRAS; Português; Design de Interface. 


\section{Abstract}

Correia, Ana Tereza Pinto de Sequeiros; Couto, Rita Maria de Souza (Advisor). Portugal, Cristina. (Co-Advisor). Design and contemporary technologies applied to create digital narrative for hearing-impaired and listener children. Rio de Janeiro, 2018. 92p. Tese de Doutorado Departamento de Artes \& Design, Pontifícia Universidade Católica do Rio de Janeiro.

The goal of this research is to provide, based on methodologies of Design in Teaching-Learning Situations, the use of inclusive resources for the development of bilingual digital narratives for hearing-impaired children, in a participatory way. It will address historical questions about oralism and gesturalism, how the acquisition of language at an early age is fundamental for children's cognitive development and the difficulties to simultaneous teaching of the Brazilian Sign Language, LIBRAS and written Portuguese. It presents a reflection about how the technology can be used as mediator for the learning of socio-cultural contents, as well as the development of sensory-motor and cognitive abilities in the process of the child's growth. And we will design a bilingual digital interactive story, conceived and developed by the team of the Interdisciplinary Design / Education Laboratory, Department of Arts \& Design, PUC-Rio (LIDE | DAD | PUC-Rio), contemplated by the Universal Call 14/2013 - CNPq, and the steps will described. At the end, it provides guidelines for the construction of interactive digital narratives with the objectives described above, in order to foster the field of Design in Partnership with Education, expanding the reach of projects of this nature for this public.

\section{Keywords}

Digital Book; Interactive Story; Deaf Children; Bilingual Interactive Digital Narrative; LIBRAS; Portuguese; Interface Design. 


\section{Sumário}

1. Introdução 12

2. A linguagem e a criança surda 18

2.1 O significado como elo entre o pensamento e a linguagem 22

2.2 O bilinguismo como fator de integração na sociedade 26

2.3 Síntese dos temas abordados 29

3. A narrativa interativa digital bilíngue na aprendizagem 31

3.1 A convergência e a ubiquidade da comunicação nas relações: um novo olhar para a criação de conteúdos interativos digitais 31

3.2 Narrativa interativa digital infantil bilíngue: explorando 36 a brincadeira e a imaginação no contexto da aprendizagem

3.3 Síntese dos temas abordados 40

4. Design na criação de narrativas interativas digitais bilíngues (LIBRAS e Português): estudo de caso 41

4.1 Metodologia de desenvolvimento do projeto 43

4.2 Descrição do processo de desenvolvimento do projeto 44

4.2.1 Pesquisa de similares e análogos 45

4.2.2 A narrativa 51

4.2.3 llustração: cenários e personagens $\quad 57$

4.2.4 As interações 60

4.2.5 As duas línguas na narrativa 68

$\begin{array}{lll}\text { 4.2.6 Storyboard } & 70\end{array}$

$\begin{array}{lll}4.2 .7 & \text { Tipografia } & 78\end{array}$

$\begin{array}{lll}\text { 4.2.8 Wireframes } & 79\end{array}$

4.3 Síntese dos temas abordados $\quad 81$

5. Conclusão 83

6. Referências bibliográficas $\quad 87$ 


\section{Lista de Figuras}

Figura 1: quadro de processo metodológico da construção da narrativa (Fonte: acervo LIDE)

Figura 2: Análise de análogos - foto do livro Pelo Rio, Editora Pallas.

Figura 3: Análise de análogos - foto do livro Grande Livro dos Medos, Editora Salamandra

Figura 4: Análise de análogos - foto do livro Aconteceu na Escola, Editora Pallas.

Figura 5: Análise de análogos - captura de tela do aplicativo Fantastic Flying Books, aplicativo MoonBot

Figura 6: Análise de análogos - imagem de internet do desenho animado para a TV Charlie Brown.

Figura 7: Análise de análogos - imagem de internet do desenho animado para a TV Doug

Figura 8: José e Ana, personagens da nossa história (Fonte: LIDE)

Figura 9: mosaico com ilustrações do Largo do Boticário e sua vegetação (Fonte: LIDE).

Figura 10: Análise de similares - captura de tela de vídeo-análise do livro "The Tale of Peter Rabbit" (Fonte: acervo LIDE).

Figura 11: Análise de similares - captura tela de vídeo promocional do livro "Timo and the Magical Picture Book (Fonte: acervo LIDE).

Figura 12: Análise de similares - captura de tela do jogo "Milk-shake" e do jogo "Snow Cone" (Fonte: acervo LIDE).

Figura 13: Análise de similares - captura de tela do vídeo promocional do livro "Floksik" (Fonte: acervo LIDE). 
Figura 14: Análise de similares - captura de tela de uma palestra do autor do livro "Our Choice", Mike Matas (Fonte: acervo LIDE)

Figura 15: Análise de similares - captura de tela de vídeo promocional do livro "Heart and the Bottle" (Fonte: acervo LIDE).

Figura 16: Análise de similares - captura de tela de vídeo-análise do livro "Toy Story” (Fonte: acervo LIDE)

Figura 17: Emanuel no teste de interpretação, no estúdio de audiovisual do DAD/PUC-Rio (Fonte: acervo LIDE).

Figura 18: Teste de proporção de interface entre ilustração, intérprete e texto no aplicativo (Fonte: acervo LIDE).

Figura 19: Storyboard da história

Figura 20: Abertura de cena (cenário, personagens e intérprete). Fonte: arquivo LIDE.

Figura 21: Personagens, cenário e ícone de avançar. Fonte: arquivo LIDE.

Figura 22: Personagens, cenário e ícones. Fonte: arquivo LIDE. 


\section{Lista de tabelas}

Tabela 2: quadro pesquisa de similares $\quad 45$

Tabela 1: quadro pesquisa de similares - livro Pelo Rio 46

Tabela 4: quadro pesquisa de similares - Livro $\mathrm{O}$

Grande Livro dos Medos

Tabela 5: quadro pesquisa de similares - Aconteceu na Escola

Tabela 6: quadro pesquisa de similares - Aplicativo Flying Books 


\section{Introdução}

Atualmente, nossa sociedade vive uma busca incessante por tempo e conhecimento. Essa situação está intimamente ligada às crianças e aos jovens e, pode-se perceber isto com a facilidade em que transitam pelo mundo virtual e a competência com que manipulam os suportes interativos. Essa questão nos faz pensar que as situações de ensino-aprendizagem estão tomando um novo rumo, ultrapassando a fronteira da escola e conduzindo a novas zonas de comunicação entre educadores e alunos. Esse movimento nos instiga a uma reflexão acerca dos métodos de ensino aplicados à Escola, que são os alicerces para a organização de sua estrutura. Propõem-se uma reflexão, então, sob à luz do Design, acerca de métodos que possam auxiliar o processo de construção da Língua Brasileira de Sinais - LIBRAS - e da Língua Portuguesa por crianças surdas, aliados à tecnologia, bem como a criação de possibilidades de interação entre crianças surdas e ouvintes.

Quando iniciei a graduação em Desenho Industrial, com habilitação em Comunicação Visual, pela PUC-Rio, em 2002, ainda não tinha a noção de quão vasto poderia ser o campo de atuação do designer. No início do ano de 2005, me candidatei a uma vaga para bolsista PIBIq no Laboratório Interdisciplinar de Design e Educação (LIDE), do Departamento de Artes e Design, da Pontifícia Universidade Católica do Rio de Janeiro (DAD/PUC-Rio), para fazer parte do grupo de pesquisa da Prof. Dra. Rita Maria de Souza Couto.

Vinculada ao LIDE, a linha de pesquisa intitulada Design em Situações de EnsinoAprendizagem, abriga investigações que tenham como tema o binômio Design/Educação. O tema da pesquisa no LIDE era o desenvolvimento de um jogo que auxiliasse à aquisição da linguagem por crianças surdas. Este trabalho teve a parceria do Instituto Nacional de Educação de Surdos, O INES, situado no Rio de 
Janeiro. Na filosofia bilinguista, corrente filosófica de alfabetização adotada pelo INES/RJ, a criança surda é alfabetizada em LIBRAS, assumindo o papel de língua falada, e pelo Português, como língua escrita.

Desde que ingressei no laboratório, conheci, me sensibilizei e não parei mais de pesquisar e escrever sobre o tema, sendo determinante para a minha entrada na área acadêmica. Concluí minha graduação com um projeto intitulado "Fábulas para Crianças Surdas” (2007), que foi apresentado no II SILID I SIMAR, em 2008. Já no Mestrado, em 2012, analisei cientificamente o jogo Multi-Trilhas Virtual, na dissertação intitulada "Multi-Trilhas Virtual: novas diretrizes para o jogo de entretenimento na aquisição da linguagem por crianças surdas”.

Desde 2005, a equipe do LIDE tem uma vasta produção de conteúdo e formação de profissionais: seis jovens cientistas, um projeto de graduação, quatro dissertações, duas teses, um apoio da FAPERJ, um Edital Universal, um apoio de material didático FAPERJ, periódicos, anais de congresso e capítulos em livros. Também compartilhamos conhecimento em artigos publicados e participações em simpósios, seminários e congressos nacionais e internacionais, como P\&D, CIPED, EDULEARN, CIDI, CPublisher, Design Principes \& Practices, EVA London, entre outros. Além da incalculável riqueza reflexiva, da criação efetiva de materiais para este público e do fomento à pesquisa.

Como esta questão ainda não ocupou seu devido lugar no que diz respeito ao investimento em políticas que estimulem a criação e a construção efetiva de materiais pensados para este fim, foi iniciada a retomada desta discussão. Contemplada com projeto de pesquisa em Edital Universal 14/2013 - CNPq, a equipe do LIDE iniciou o desenvolvimento de um livro interativo digital, à luz do Design em Situações de Ensino-aprendizagem.

Apesar do cunho de aprendizagem bilinguista, o intuito deste projeto de pesquisa é a inclusão. Portanto, seu conteúdo é orientado e ampliado de acordo com necessidades voltadas para crianças surdas, mas não exclusivamente para elas. Assim, foram desenvolvidas estratégias que possibilitem igualmente seu uso por crianças ouvintes. Dessa forma, este público também terá acesso ao bilinguismo, e 
poderá aprender a como se comunicar com pessoas com surdez, estimulando a interação entre crianças surdas e ouvintes.

Em observações no INES e por relatos de professores, constatou-se que um grande obstáculo na alfabetização de crianças surdas é realizar a correspondência entre esses dois idiomas. Quando uma criança ouvinte é alfabetizada pelo Português, ela tem contato com o exercício da escrita e o da fala. Nesta língua, por exemplo, toda palavra acentuada tem sua representação na escrita. Ou seja, quando ensinada, a Língua Portuguesa utiliza recursos orais para apresentar as palavras escritas às crianças. Por seu turno, apesar de ter estruturas morfológicas, semânticas e léxicas próprias como qualquer outra língua, a LIBRAS é composta apenas pela fala, sendo esta representada pelas linguagens gestual, facial e corporal. Ou seja, ela é basicamente visuoespacial. Outra diferença entre essas línguas é que na LIBRAS não conjugamos verbos nem utilizamos preposições ou conectivos, como no Português. Por esses motivos, o ensino de ambas simultaneamente torna-se muito complexo. Porém, estudos mostram que se apresentadas à linguagem na mais tenra idade, as crianças surdas desenvolvem-se da mesma forma que as crianças ouvintes. Ou seja, a limitação para que uma criança surda (salvo os casos em que a surdez é acompanhada de alguma outra necessidade especial) não se desenvolva adequadamente deve-se à privação do ensino da linguagem.

Participamos de seções de contação de histórias na biblioteca do INES. Uma das formas encontradas pelos professores para a alfabetização de crianças é o ato de contar histórias. As histórias despertam a criatividade e (re)criam cenas e emoções únicas na imaginação, desenvolvendo a cognição e estímulos sensoriais. Por meio delas é possível fazer analogias, aprender novas palavras, familiarizar-se mais com o idioma, construir relações e interpretar a narrativa. Porém, praticamente não há registros de materiais desenvolvidos especialmente e exclusivamente para este fim. Em geral, professores improvisam, lendo, por exemplo, histórias em quadrinhos já existentes e indicando as palavras escritas em Português, motivando as crianças a estabelecerem a correlação com a LIBRAS. Esta prática ajuda as crianças a se tornarem parte integrante do exercício, estimulando a concentração e facilitando a apreensão do conteúdo. 
Diante do exposto, o problema que norteou a presente tese é a escassez de materiais eficientes, atrativos e contemporâneos voltados especialmente, mas não exclusivamente, para a aquisição de competência bilíngue de crianças surdas.

A investigação empreendida tem como foco o potencial da parceria entre Design e Educação e tem como objeto de pesquisa o processo de criação de uma narrativa digital interativa bilíngue para crianças surdas e ouvintes, que contextualiza o uso da LIBRAS e do Português.

Contempla como objetivo geral investigar as diversas relações do Design em Situações Ensino-aprendizagem no tocante ao desenvolvimento de narrativas interativas, tendo como foco estudos sobre ambientes hipermidiáticos direcionados à crianças surdas e o bilinguismo.

Apresenta como objetivos específicos:

a) Explicar a importância da linguagem na formação do indivíduo surdo, tendo o bilinguismo como fator de sua integração na sociedade;

b) Elaborar uma narrativa interativa digital para auxiliar o processo de aprendizagem por crianças surdas.

c) Possibilitar a interação entre crianças surdas e ouvintes por meio de uma narrativa lúdica;

d) Descrever o processo de desenvolvimento da narrativa interativa digital bilíngue;

A questão norteadora desta tese é: como o Design em situações de EnsinoAprendizagem é capaz de promover a criação de narrativas interativas digitais bilíngues para crianças surdas e ouvintes?

Pode-se justificar e estabelecer a relevância para este estudo por meio dos eixos social, acadêmico, educacional e pessoal.

A função social desta tese é tentar diminuir as barreiras entre pessoas surdas e ouvintes no que diz respeito à comunicação. Disponibilizar orientações que ajudem a nortear a criação de ferramentas interativas digitais bilíngues as quais possam ser 
incorporadas a qualquer projeto infantil é apenas um começo para que grupos de desenvolvedores pensem a respeito e possam atingir o maior número de usuários surdos e ouvintes.

$\mathrm{Na}$ contemporaneidade, a tecnologia tem sido uma importante aliada para a aprendizagem e disseminação de informação. Ao abordar questões de caráter inclusivo do ponto de vista do Design, a presente tese fomenta a reflexão sobre como podemos e devemos pensar a respeito do potencial do Design em Situações de Ensino-Aprendizagem e sobre a possibilidade de transformar a vida de inúmeras pessoas que, geralmente, não são foco do grande mercado de produção de conteúdo digital. Assim sendo, busca-se abordar questões referentes ao campo da Educação, sob a luz da discussão da inclusão educacional, e sobre como o Design é capaz de estabelecer novas relações entre pessoas e o meio em que vivem, promovendo o diálogo entre a comunidade surda e a ouvinte.

O Design, com seu caráter interdisciplinar e investigativo, é capaz de contribuir por meio de seu processo metodológico, viabilizando meios concretos e eficazes para transpor as barreiras da dificuldade da inclusão educacional no contexto da educação infantil.

A importância de projetos de materiais que possam ser utilizados no âmbito da escola para auxiliar a aquisição da linguagem por crianças surdas e o despertar do interesses da LIBRAS por crianças ouvintes dá margem para a discussão sobre como a escola pode avançar, tanto no que diz respeito aos materiais didáticos e paradidáticos, como na formação de professores e na reflexão de diferentes maneiras de ensino para crianças que precisam de incentivos específicos.

Meu interesse por este tema começou na graduação do curso de Desenho Industrial da PUC-Rio, em 2005, quando conheci o Laboratório Interdisciplinar Design e Educação e o trabalho que minha orientadora liderava na ocasião, o Multi-Trilhas ${ }^{1}$.

\footnotetext{
${ }^{1} \mathrm{O}$ projeto do Multi-Trilhas foi desenvolvido pela equipe do Laboratório Interdisciplinar Design/Educação (LIDE/DAD/PUC-Rio), sob a coordenação da Professora Rita Maria de Souza Couto em parceria com o Instituto Nacional de Educação de Surdos, o INES/RJ, entre 2005 e 2007. A equipe multidisciplinar era composta por professores e estudantes graduados e pósgraduados em Design com especialização em Pedagogia, assim como professores do INES. O projeto teve duas vertentes: a concreta, disponibilizada em formato de jogo, e a virtual, disponibilizada em formato de atividade pedagógica.
} 
Descobrir que o Design poderia criar e fornecer estratégias e produtos que realmente atingissem um público que necessita ser enxergado, me deu motivação para perseguir projetos de pesquisa com esta finalidade.

Os dois maiores incentivos são ter uma equipe que também compartilha desse objetivo e ver o resultado aplicado às crianças surdas sendo disseminado na academia, despertando o interesse de muitos outros projetos de pesquisa com este fim.

A tese apresenta dois desdobramentos, um de fundamentação teórica e outro empírico. A parte teórica aborda a questão da importância da aquisição linguagem na mais tenra idade e a relevância desse fato na vida de crianças surdas que, em muitos casos, tem contato com a língua de sinais apenas quando ingressam em uma instituição especializada de ensino. Traz, ainda, uma reflexão acerca do uso de novas tecnologias e da brincadeira como fatores importantes no processo de aprendizagem. A parte empírica descreve o planejamento e a criação do objeto analisado, realizando considerações sobre esse processo e disponibilizando orientações para futuros projetos similares.

A presente pesquisa tem caráter exploratório e é de natureza qualitativa, pois fez-se necessário o aprofundamento da investigação nas relações entre o público alvo e as nuances pertinentes à sua realidade (GIL, 1999). A narrativa interativa digital bilíngue para crianças surdas e ouvintes foi objeto do estudo de caso e teve todas as etapas de planejamento e execução descritas e, posteriormente, analisadas. A participação e acompanhamento desse processo promoveu o aprofundamento, devido ao foco e recursos concentrados em um objeto único de estudo.

Em relação às técnicas de coleta de dados, a pesquisa bibliográfica foi utilizada para embasar ideias, estudo de similares e trazer autores pertinentes a este campo, apoiando suas teorias. A observação comportamental do público em questão também fez parte das técnicas de pesquisa do processo metodológico adotado, a fim de "identificar e obter provas a respeito de objetivos sobre os quais os indivíduos não tem consciência, mas que orientam seu comportamento" (MARCONI \& LAKATOS, 1996, p. 79). 


\section{A linguagem e a criança surda}

A descoberta da linguagem pela criança começa dentro de casa. Após o seu nascimento, o contato com a mãe é muito importante para o seu desenvolvimento e sua familiarização com a língua natal e todos os valores socioculturais enraizados e transmitidos por ela.

Nessa relação, as entonações utilizadas pela mãe ${ }^{2}$, sua expressão facial, assim como as vibrações em seu corpo, causadas por sua fala, em contato com a criança, por exemplo, propiciam que as primeiras descobertas do mundo sejam realizadas. Quando a mãe fala com a criança, ela está estimulando-a a todo momento na superação de novos desafios e a desvendar o mundo que a cerca. É importante que, mediante respostas positivas sobre determinado estímulo, a mãe proponha novas situações para encorajar a criança a dar mais um passo em relação à sua aprendizagem. Isso mantém seu constante desenvolvimento e garante que esteja apta a alcançar novas fronteiras durante seu crescimento.

No primeiro ano de vida, a criança desenvolve reações afetivas pela fala emocional, representadas pelo choro e pelo balbucio das primeiras palavras (VYGOTSKY, 2008, pág. 52) ${ }^{3}$. Essa linguagem pré-verbal é dotada de valores emocionais ligados à linguagem que a mãe compartilha com a criança. No decorrer de seu desenvolvimento, a criança internaliza essa linguagem materna e permite que seu mundo perceptivo, transmitido pela mãe e por suas experiências até o momento,

\footnotetext{
${ }^{2}$ Geralmente, a mãe é a pessoa mais próxima da criança. Mas, lógico, que diante de fatos que modifiquem essa premissa, é importante que esse papel seja alterado para a pessoa mais próxima da criança

${ }^{3}$ VYGOTSKY, L.S. Pensamento e Linguagem. $4{ }^{\text {a }}$ Ed. - São Paulo: Martins Fontes, 2008.
} 
seja levado para o mundo conceitual. Ou seja, começa a fazer novas relações e a reconhecer símbolos e seus significados.

Em um lar onde os pais são ouvintes e o filho é surdo, muitas vezes, mesmo sem querer, cria-se um ambiente desfavorável para a socialização da criança, não pelo fato da surdez em si, mas porque os pais não sabem como se comunicar com o filho. Durante meu Mestrado (2010 a 2012), em observações assistemáticas no Instituto Nacional de Educação de Surdos, o INES, em Laranjeiras, no Rio de Janeiro, alguns professores relataram que grande parte das crianças que chegam à instituição não tiveram contato com a Língua Brasileira de Sinais, a LIBRAS, e aprenderam a se comunicar dentro de casa por meio de gestos rudimentares e populares, por sinais facilmente identificados de acordo com o contexto social em que vivem, e não por meio de uma linguagem sígnica. Esse fato acaba isolando a criança do convívio com os membros da família e restringe suas relações a uma comunicação bem básica, desfavorecendo o estreitamento de laços e a participação da criança em situações domésticas comuns do dia a dia.

Da mesma forma que a carência de estímulos auditivos pode comprometer o desenvolvimento inicial de uma criança ouvinte, a falta de estímulo visual para a criança surda também restringe o seu desenvolvimento. Filhos de pais surdos tendem a ser estimulados nesta fase com brincadeiras visuais e gestuais ricas, pois estes compreendem essa necessidade por estarem em sua natureza comunicacional. Mesmo cercados de esforços e boa vontade, pais ouvintes são naturalmente seres auditivos, o que dificulta essa compreensão e o estímulo visual necessário à criança surda nessa fase.

Imagine um bebê surdo com pouca ou nenhuma percepção dos sons. Quando olha para um objeto ou evento, ele nada recebe da mood music (aquela que se destina a transmitir determinado estado de espírito ao ouvinte) que acompanha a experiência social do bebê ouvinte. Suponha que ele olhe para um objeto de sua atenção e depois para um adulto que está "compartilhando" a experiência com ele, e que o adulto fale sobre o que o bebê acabou de ver. Será que o bebê pelo menos chega a perceber que está ocorrendo uma comunicação? Para descobrir relações entre uma palavra e seu referente, o bebê surdo tem de lembrar algo que acabou de observar e associar essa lembrança a uma outra observação. O bebê surdo tem que fazer muito mais, "descobrindo" as relações entre duas 
experiências visuais muito diferentes que são deslocadas no seu tempo. (WOOD, 1986, apud, SACKS, 1998, p. 75) ${ }^{4}$.

Essa abordagem ressalta como o contato com a mãe é essencial para o desenvolvimento intelectual e da fala da criança, seja ela oral ou gestual. E, nos casos onde os pais são ouvintes e o filho é surdo, é fundamental que eles aprendam a LIBRAS e busquem atividades hiper visuais, colaborando, assim, para o desenvolvimento da criança.

Até a fase de aquisição de uma linguagem viso-espacial específica, natural às suas condições - assim como a linguagem oral é natural aos ouvintes, a língua de sinais é natural aos surdos -, a criança surda opera com seu pensamento de forma restrita, ou seja, não é capaz de estruturá-lo e utilizar a palavra como meio gerador de significados, utilizando-a apenas como um sinal identificador de ações e necessidades 5 .

Como ressalta Schlesinger (1972, apud SACKS, 1998, p. 76), a surdez detectada numa criança é mais do que um diagnóstico médico. É um fator cultural, que reflete em questões sociais, intelectuais, linguísticas e emocionais. Em pesquisas de campo e por relatos de professores do INES, foi possível detectar que crianças com surdez têm dificuldade de compreender o espaço de tempo e valores socioculturais intrínsecos na sociedade na qual vivem. Não apenas a língua é diferente, mas também suas necessidades e a forma de comunicação.

Em uma sala de aula, é possível observar como crianças surdas têm melhor percepção de outros sentidos, como o tato, por exemplo. Qualquer vibração não passa desapercebida. Em uma mesa grande, geralmente, quando uma criança quer chamar uma segunda que está outra ponta, ela dá um tapa forte do tampo. Pela vibração, a criança do outro lado entende que existe alguém chamando-a e olha, fazendo contato visual e esperando a fala por meio da língua de sinais. Para um

\footnotetext{
${ }^{4}$ SACKS, Oliver W. Vendo Vozes: uma viagem ao mundo dos surdos. São Paulo. Companhia das Letras: 1998.

${ }^{5}$ Ou seja, apenas usa os gestos como forma de comunicação primitiva para expressar algo que tem necessidade e ainda não tem na palavra uma fonte de riqueza de significados para estruturar em seu pensamento o que deseja falar.
} 
ouvinte, essa situação poderia não ser percebida, já que a audição é o sentido natural para chamar a atenção de uma outra pessoa requisitada.

Outro exemplo é em relação à intensidade do toque: ouvintes se tocam nos ombros de forma mais branda. Para os surdos, é natural um toque nos ombros com mais força. Em uma situação comum num ambiente com pessoas ouvintes, muitos reclamam quando um colega fica "cutucando" a toda hora, já que existem outras formas de se pedir atenção, como falando. No universo do indivíduo surdo, o toque não se torna irritante. Ele é um meio que pode promover o início de sua comunicação.

Essas são algumas situações que nos fazem refletir sobre como é preciso conhecer para entender o espaço e a forma de comunicação de pessoas com surdez. Elas não são menos capazes que os ouvintes, porém têm necessidades e habilidades diferentes. Quando observamos uma criança ouvinte aprendendo a falar, notamos que a pronúncia das sílabas ainda é confusa, há troca de sons de uma letra por outra, tornando a fala pouco clara. Existe um caminho a ser percorrido de aprendizado na pronúncia e na formação das palavras. Numa criança surda essa percepção do aprendizado da fala é a mesma, mas analisada de acordo com características inerentes de sua própria fala, a língua de sinais. Como os movimentos gestuais, faciais e corporais ainda estão em desenvolvimento no início do aprendizado, os gestos ainda não são precisos. Porém, com o passar do tempo, nota-se que o refinamento dos movimentos fica mais evidente, da mesma forma que a dicção e a pronúncia ficam mais claras em crianças ouvintes.

Há de se entender que a pessoa com surdez está apta a aprender e produzir conhecimento. Não há nenhum retardo nem déficit de aprendizagem em relação à pessoa ouvinte. O contato com a língua de sinais deve ser tão natural para crianças surdas, como a língua oral é para as crianças ouvintes, pois elas se desenvolvem de forma simultânea, desde que convivam com suas línguas próprias na mais tenra idade. A questão da relação da linguagem com o pensamento deve ser encarada como fator extraordinário para o desenvolvimento de qualquer indivíduo, ainda mais na criança com surdez que, na maioria dos casos, tem um contato tardio com a linguagem (CORREIA, 2012, p. 19). 
A linguagem é a porta para desvendar a si mesmo e para constituir-se como membro ativo em suas próprias ideias. Por meio dela é possível organizar e expressar o pensamento para a construção de nossa real identidade e para o convívio em sociedade, assim como aponta Julia Kristeva ${ }^{6}$ :

Se a linguagem é a matéria do pensamento, é também o próprio elemento da comunicação social. Não há sociedade sem linguagem, tal como não há sociedade sem comunicação (KRISTEVA, 1969, p. 18).

Assim, o pensamento do indivíduo com surdez pode ser estruturado pela língua nativa, a LIBRAS, e pela segunda língua, no caso do Brasil, o Português escrito, que possibilitará que ele se insira no contexto no qual vive. Lógico que em paralelo à iniciação da alfabetização feita pela escola, o ideal é que a família esteja em sintonia, no mesmo ritmo. Por isso, pais ouvintes que se interessam pela LIBRAS acabam conduzindo o filho com surdez a um mundo possível de ser descoberto, possível de interação, dando chance à criança de participar ativamente na construção do seu próprio eu e de seu futuro.

\section{1}

\section{O significado como elo entre o pensamento e a linguagem}

Para entender como ocorre a formação social da mente, é necessário olhar mais profundamente para a relação entre o pensamento e a linguagem no processo intelectual de desenvolvimento da criança. $\operatorname{Vygotsky}^{7}(2009$, p.5) propôs que o estudo dessa relação fosse feito pela análise em unidades $^{8}$. Dessa forma, chegou à conclusão de que o significado da palavra contém esse aspecto e deve ser considerado como a unidade do pensamento e da linguagem.

Encontramos no significado da palavra essa unidade que reflete da forma mais simples da unidade do pensamento e da linguagem. (...) A palavra desprovida de significado não é palavra, é um som no vazio. Logo, o significado é um traço constitutivo indispensável da palavra. (...) Mas, como nos convencemos reiteradas vezes, ao longo e nossa investigação, do ponto de vista psicológico o significado da palavra não é senão uma generalização ou conceito. (...)

\footnotetext{
${ }^{6}$ KRISTEVA, Julia. História da Linguagem. Tradução Maria Margarida Barahona. Edições 70 Lisboa, Portugal: Coleção Signos, 1969. Julia Kristeva é uma filósofa búlgara-francesa, nascida em 1941. Atua na corrente de pensamento estruturalista e estuda temas nas áreas de linguística, teoria e crítica literária, psicanálise, entre outros.

7 VYGOTSKY, L.S. "Pensamento e Palavra" In A Construção do Pensamento e da Linguagem; tradução Paulo Bezerra - 2 ${ }^{\mathrm{a}}$ Ed. - São Paulo: Editora WMF Martins Fontes, 2009.

${ }^{8}$ A análise em unidades avalia um produto que detém todas as propriedades básicas do todo, pelo o qual não é possível haver separação sem que suas propriedades não se percam.
} 
Consequentemente, estamos autorizados a considerar o significado da palavra como um fenômeno do pensamento (VYGOTSKY, 2009, p. 398).

O significado de uma palavra é um conjunto de suas definições usado pelo pensamento para construir sua linha de raciocínio, e que pode ser realizado pela linguagem. A relação entre pensamento e palavra é um movimento de fluxo intermitente, onde a palavra serve ao pensamento e o pensamento serve à palavra. E, mesmo com essa relação estabelecida, o pensamento jamais será executado $100 \%$ na palavra e vice-versa. Quando pensamos, fazemos nossas próprias significações decorrentes de nosso raciocínio e de valores apreendidos no decorrer de nossa experiência. Por meio dele, escolhemos as palavras que julgamos mais convenientes em cada situação, em diferentes contextos. Em contrapartida, a palavra, quando recebida por nosso pensamento, é capaz de nos trazer memórias e referências únicas em nós (VYGOTSKY, 2009).

Os progressos do pensamento e da linguagem ocorrem em ritmos diferentes, cruzando-se e separando-se novamente ao longo do desenvolvimento da criança. E este processo não engessa o significado das palavras; ao contrário, permite que se desenvolva de acordo com experiências e situações as quais seremos submetidos ao longo do processo de aprendizagem.

Em seu processo de desenvolvimento sígnico, a criança atribui a um objeto duas ou três palavras referentes a propriedades concretas do mesmo, como o cachorro faz “au au” e é peludo. O elefante tem tromba e é grande. Isto porque seu pensamento ainda está em formação e busca na linguagem palavras para atribuir e definir coisas e objetos do mundo que está conhecendo. Dessa forma, para ela, ainda não é tão simples separar o objeto de suas propriedades. Diferentemente de um adulto, a criança entende o nome do objeto como parte do mesmo e não como a palavra que carrega significados para a sua determinação.

A fase pré-linguística faz parte da evolução do pensamento, assim como a fase préintelectual faz parte da evolução da linguagem. Na fase pré-linguística, a criança ainda não tem o conhecimento da linguagem para estruturar seu pensamento, mas ela consegue, por meio de questões afetivas, entender como expressar suas necessidades. A criança pode chorar para comunicar que está com fome, como pode 
apontar para comunicar que quer determinado objeto. Por seu turno, a fase préintelectual faz parte do processo de evolução da linguagem porque é esta que fornece meios concretos de fomentar o raciocínio da criança, possibilitando que seus conceitos sejam formados não apenas por sua vontade, mas por sua habilidade intelectual.

Quando adquire a linguagem, o pensamento da criança amadurece e ela se torna capaz de fazer a diferenciação consciente de significados e a atribuí-los mais precisamente para concretizar seu pensamento. Esse encontro entre pensamento e linguagem torna o pensamento verbal e a linguagem racional. A língua se torna rica em signos, como defende Mikhail Bakhtin?. Para o autor, existem grandes diferenças entre o sinal e o signo. O primeiro é identificado e o segundo, decodificado. Assim, a palavra é carregada de conceitos (BAKHTIN, 1988, p. 92). Podemos perceber que a princípio, ela é um sinal que identifica determinado objeto. Conforme aprendemos a utilizá-la, passa a ser decodificada, adotando generalizações, operando por seu significado e não mais apenas como uma mera associação entre o objeto e seu símbolo.

E por que essa relação é crucial para o desenvolvimento de qualquer indivíduo? Após aprender uma língua, a pessoa desvenda um mundo antes inexplorado. Aprende a se colocar como indivíduo e a dar significado às coisas, assim como se situar temporal e espacialmente. Isso permite a sua formação e ação plena na sociedade na qual vive, tirando-o da esfera de observador e dando-lhe o papel de agente.

Para se constituir plenamente, o pensamento precisa de uma ferramenta de organização, onde possa articular suas ideias. A linguagem funciona como esse alicerce, podendo operar em meios distintos, como o pensamento, a fala (oral ou

\footnotetext{
${ }^{9}$ BAKHTIN, Mikhail (V.N. Volochínov). "Língua, Fala e Enunciação” In Marxismo e Filosofia da Linguagem: problemas fundamentais do método sociológico na ciência da linguagem. "A Interação Verbal” In —. Tradução Michel Lahud e Yara Frateschi Vieira; colaboração Lúcia Teixeira Wisnik e Carlos Henrique D. Chagas Cruz. 4ª Ed. - São Paulo: Editora Hucitec, 1988. Mikhail Mikhailovich Bakhtin (1895 - 1975) foi um linguista russo que estudou Filosofia e Letras na Universidade de São Petersburgo. Fez uma crítica à Teoria da Comunicação antes mesmo que esta fosse estabelecida. Defende a ideia de que para se ler um texto é necessária a compreensão do contexto e para compreender este ultimo, é necessário entender os meios de produção da época. Estudou a palavra como um processo de compreensão, não como um acontecimento em linha reta.
} 
gestual) e a escrita. Todos diferentes entre si, tanto em sua estruturação, como em sua finalidade (CORREIA, 2012, p.23).

Quando construímos uma frase, usamos a linguagem para estruturá-la de forma inteligível, para mantermos um diálogo lógico e coerente com o outro. Por mais que tenhamos normas e regras também para a fala, é na escrita que geralmente desempenhamos o papel máximo das estruturas gramaticais, semânticas e ortográficas da língua. Já o pensamento é o primeiro passo para a ação da fala ou da escrita. Ele pode, inclusive, jamais ser revelado por nenhuma delas, mantendose inacessível ao mundo externo.

Em suas pesquisas com grupos de crianças, Vygotsky (1998, p. 142) analisou que o gesto que a criança faz ao se expressar são os primeiros indícios da futura escrita. Desde cedo, a criança (surda ou ouvinte) constrói associações do que quer demonstrar com gestos que indicam essa necessidade. Essa ligação com os gestos também pode ser observada no desenho infantil. Durante o amadurecimento, a criança faz rabiscos em determinada superfície, querendo indicar alguma figura que lhe é familiar. Por exemplo, quando solicitada a desenhar o sol, a criança imaginao e, muitas vezes, desenha rabiscos no papel. Para adultos, que tendem a entender o desenho como a representação icônica de determinado elemento real, os traços são apenas rabiscos que indicam que a criança ainda não consegue desenhar corretamente o que lhe foi pedido.

Para a criança, como aponta Vygotsky (2009, p. 142) esse é o primeiro estágio do desenvolvimento da escrita. A criança entende o que lhe foi solicitado, usa a memória para compreender e finaliza com gestos ou com rabiscos o que está em sua mente. A representação está sendo mentalmente visualizada pela criança, mas ela ainda está desenvolvendo seus primeiros esboços explorando o uso de ferramentas como o lápis e o papel. Portanto, ainda não tem domínio da técnica, desenhando, primeiramente, rabiscos que completam o seu raciocínio. Da mesma forma, quando a criança começa a falar, as palavras não são pronunciadas de uma só vez. Elas demoram a se formar por completo em sua pronúncia, sílaba por sílaba.

Para o indivíduo, aprender uma linguagem é ter acesso ao mundo e à capacidade de desenvolvimento intelectual e sígnica. É por meio das palavras, pela denominação 
das coisas que se pode ter o controle do que se pretende dizer. Assim, a pessoa adquire o domínio de suas intenções, tão logo, sua independência e a capacidade de se expressar.

\section{2}

\section{O bilinguismo como fator de integração na sociedade}

O oralismo e o gestualismo constituem duas grandes correntes filosóficas para o ensino de surdos. $\mathrm{O}$ oralismo restrito sugere que não exista diferença entre surdos e ouvintes e que estes sejam tratados como "iguais" perante o ensino da mesma língua. Seu objetivo é ensinar ao surdo a língua oral, praticada por ouvintes, por meio da prática da leitura labial. Já na corrente gestualista, raramente exercida radicalmente, entende-se que é natural ao surdo comunicar-se por meio de sinais, assim como é natural aos ouvintes comunicar-se por sons. Propõem-se o ensino na língua de sinais o quanto antes para a criança com surdez, permitindo seu desenvolvimento desde os primeiros anos de vida.

A educação de surdos se iniciou no século XVI, na Espanha, mas não há registros do sistema utilizado. O primeiro livro de educação para surdos foi publicado em 1620, por Juan Pablo Bonnet ${ }^{\mathbf{1 0}}$. Nele, o autor deixa clara a importância do alfabeto manual ser inserido na vida dos indivíduos com surdez.

Antes de 1750, a situação das pessoas surdas era extremamente precária e sua alfabetização quase inexistente. Os mudos, como eram denominados, não eram reconhecidos como cidadãos e desempenhavam papéis sem relevância no mercado de trabalho. Além desses problemas, conviviam com a interminável busca do seu próprio eu, pois não tinham como constituir seu pensamento, diante da privação da alfabetização e da fala. Poucos, muito poucos, obtinham esse privilégio. Apenas a alta sociedade, a muito custo, alfabetizava seus filhos surdos para que esses pudessem ser reconhecidos socialmente.

Em 1756, a primeira escola para surdos foi fundada na França, com correntes filosóficas manualista e oralista. Em 1880, foi realizado o Congresso Mundial de Surdos em Milão, com o objetivo de estabelecer normas internacionais para

\footnotetext{
${ }^{10}$ Juan Pablo Bonnet foi um padre espanhol, educador e pioneiro da educação de surdos.
} 
educação de indivíduos com esse tipo de diferença. Vale registrar que nesse congresso foi proibida a participação de pessoas surdas. A corrente oralista foi a adotada e a língua de sinais foi proibida, banida das escolas para educação de surdos.

Olivers Sacks ${ }^{11}$, em seu livro 'Vendo Vozes', estudou a surdez e as correntes de alfabetização para indivíduos surdos. Concluiu, ao acompanhar casos de crianças profundamente surdas que tiveram contato com a língua de sinais nos primeiros anos de vida e de crianças que foram privadas desse ensino que:

O aspecto essencial é: pessoas profundamente surdas não mostram em absoluto nenhuma inclinação inata para a fala. Falar é uma habilidade que tem que ser ensinada a elas, e constitui um trabalho de anos. Por outro lado, elas demonstram uma inclinação imediata e acentuada para a língua de sinais que, sendo uma língua visual, é para essas pessoas totalmente acessível (SACKS, 1998, p. 43).

O autor também fala sobre a educação de surdos realizada em escolas com filosofia oralista e mostra que as crianças eram proibidas de usar não só a Língua Britânica de Sinais, mas quaisquer outras expressões gestuais para se comunicarem, pois estavam sendo alfabetizadas na língua oral. Mesmo assim, escondidas dos professores e coordenadores, essas crianças criavam gestos, uma convenção de códigos fundamentados pelos próprios estudantes, e os utilizavam na ausência de pessoas ouvintes. E, dessa forma, podiam ser eles mesmos, sem imposições ou restrições (SACKS, 1998, p. 26).

Apenas em 1971 a língua de sinais foi valorizada novamente e em 1975 chegou-se à conclusão de que o oralismo, antes adotado, não solucionou o problema da educação de surdos e de sua inclusão na sociedade. Em 1981, pesquisas realizadas em diversos países tiveram por foco o bilinguismo, que pressupõe o convívio do indivíduo surdo com duas línguas. A pedagogia bilinguista de ensino pressupõe que o ensino da língua dos sinais deve ser apresentada aos alunos em primeiro lugar, seguida pela língua escrita local. Elas são usadas em situações diferentes e podem se complementar para que o indivíduo com surdez exerça seu papel como sujeito

\footnotetext{
${ }^{11}$ SACKS, Oliver W. Vendo Vozes: uma viagem ao mundo dos surdos. São Paulo. Companhia das Letras: 1998. Era um neurocirurgião inglês e professor da NYU School of Medicine.
} 
ativo em uma sociedade formada em sua maioria por ouvintes.

Um século antes da proibição das línguas de sinais, seu uso era permitido no American Asylum of Deaf ${ }^{12}$, onde muitos alunos, além de se alfabetizarem, tornaram-se autores de destaque.

No Brasil, o bilinguismo foi adotado pelo Instituto Nacional de Educação de Surdos, o INES, como filosofia de ensino. Deve-se ter atenção em relação ao uso das duas línguas, pois a língua de sinais não pode ser considerada como uma transliteração da escrita. Ela tem estrutura gramatical, léxica, semântica e morfológica própria, assim como a língua ensinada para a escrita (mesma oral para os ouvintes). Apresenta ainda elementos característicos; os movimentos das mãos são específicos e dotados de particularidades e normas para sua utilização. Além dos movimentos das mãos, só é possível se comunicar corretamente quando as expressões faciais e corporais são exercidas plenamente.

O processo de aprendizagem acontece no mesmo ritmo para crianças surdas e ouvintes, desde que apresentadas à linguagem na mais tenra idade. Quanto mais cedo forem expostas à linguagem natural às suas necessidades, maiores serão as chances de elas desenvolverem relações cognitivas essenciais para a sua formação.

Para a criança surda, o bilinguismo é a chave para a integração na sociedade na qual vive. A LIBRAS é a segunda língua oficial no Brasil e, mesmo assim, seu ensino é restrito a instituições especializadas, apesar da Lei de Diretrizes e Bases para a inclusão de surdos em escolas regulares.

No INES, a maior instituição especializada do país, em entrevistas feitas pelos pesquisadores do LIDE com professores, foi constatada a escassez de materiais didáticos e paradidáticos elaborados para auxiliar o ensino das duas línguas. Fazer a relação entre as duas línguas não é simples e desenvolver materiais com esta finalidade menos ainda. Como forma de tentar preencher essa lacuna, alguns

\footnotetext{
12 American Asylum for the Deaf, em Connecticut, era uma escola onde o uso da língua de sinais era livre entre professores e alunos. Foi fundada em 1817 por Thomas Gallaudet e Laurent Clerc. O sucesso da escola logo levou à abertura de novas escolas. Muitos alunos e professores surdos passaram por lá, trazendo e levando experiências, contribuindo, assim, para a criação de uma língua cada vez mais aperfeiçoada.
} 
professores ensinam a relação da LIBRAS com o Português escrito por meio de quadrinhos. Eles contam a história na língua de sinais e, em determinado momento, pedem para um aluno ler o que está escrito em Português escrito e mostrar o sinal correspondente à palavra.

Outro agravante relatado por professores é a falta de materiais que auxiliem a concentração das crianças surdas. Como seu estímulo tem que ser intenso e extremamente visual, os professores têm mais dificuldade em reter sua atenção, pois não têm materiais voltados exclusivamente para este fim. Em minha graduação em Design, criei uma narrativa concreta interativa utilizando a fábula A Cigarra e as Formigas. A história foi decupada em 5 cenas, cada uma delas foi ilustrada e, posteriormente, adesivada em pranchas imantadas no formato A3. No rodapé de cada cena, havia a sua descrição em Português escrito. Além das pranchas, havia alguns personagens ilustrados falando em LIBRAS e pequenos acessórios, como a viola da Cigarra e mantinhas das Formigas, que eram imantados e podiam ser adicionados às cenas pelas crianças.

A metodologia de uso era a seguinte: a professora colocava todas as cenas alinhadas na sequência e contava a história em LIBRAS, indicando algumas palavras em Português escrito, no rodapé das cenas, para as crianças usarem a LIBRAS. Quando ela abriu a caixa com os ímãs, as crianças, que antes não estavam tão atentas à contação da história, começaram a buscar as peças e a completar a história. Elas queriam participar mais, trocavam os ímãs, falavam com a professora, queriam saber mais dos personagens e sorriam, pedindo que a professora contasse a história novamente.

Este teste foi realizado na instituição em 2007, com crianças de 7 a 8 anos, na primeira série. Concluímos que quando participam ativamente da atividade proposta, a mesma torna-se rica em momentos interativos; onde a criança se torna agente, sua concentração e seu interesse aumentam, otimizando o aprendizado do conteúdo que está sendo exposto.

\section{3}

\section{Síntese dos temas abordados}

Concluindo este capítulo, conseguimos entender tanto a essencialidade da aquisição 
da linguagem para qualquer criança desde a mais tenra idade quanto a necessidade de estímulos constantes não apenas pela escola, mas, primeiramente, por seus pais e responsáveis para que ela possa seguir um ritmo progressivo em seu desenvolvimento.

Cada necessidade especial deve ser respeitada e encarada pelos pais como um desafio na criação de seu filho e não como uma barreira para a sua comunicação. A criança que tem uma particularidade específica precisa de estímulos coerentes que fortaleçam o seu crescimento, como qualquer outra criança, e não de posturas paternalistas e super protetoras. Ela deve se "jogar" no mundo e dele experimentar sensações e vivências para que possa se tornar um cidadão ativo na sociedade.

A forma como encaramos a inclusão está em constante construção e a cada dia e cada novo projeto ou lei publicada temos a oportunidade de refletir acerca deste assunto e de perceber que os meios para que de fato pessoas com necessidades especiais se sintam incluídas de forma genuína é entender que ser diferente não significa ser menos capaz. Devemos ampliar o nosso olhar e buscar meios não de concentrar o conhecimento, mas de compartilhá-lo com profissionais de diferentes formações. Essa oportunidade é um caminho para que o Design em situações de ensino-aprendizagem seja inserido e possa colaborar com o seu processo metodológico na formação de equipes multidisciplinares, onde professores, pedagogos e designers, por exemplo, trabalhem em conjunto para criarem estratégias eficientes para o ensino do bilinguismo, com conteúdos interessantes e interativos para crianças surdas, além de contribuir com políticas de incentivo a este tipo de projeto.

Por isso, é necessário também analisar os meios disponíveis atualmente, capazes de amplificar o alcance e o engajamento diante de conteúdos voltados para crianças. Não é possível enxergar a aprendizagem como há tempos atrás. A cada nova geração, descobrimos novas habilidades infantis e vemos que a relação com a tecnologia é tão fluida, como para algumas gerações atrás era com outros suportes de comunicação. 


\section{A narrativa interativa digital bilíngue na aprendizagem}

O crescimento da tecnologia em diversos ramos do entretenimento tem ampliado a reflexão acerca de seu uso como possível ferramenta no auxílio para o ensino e para a aprendizagem, em materiais paradidáticos. Sob essa ótica, analisaremos como a narrativa interativa digital pode colaborar, tendo os suportes hipermidiáticos ${ }^{13}$ como mediadores nessa relação. Para tanto, precisaremos entender como a convergência e a ubiquidade da comunicação estão contribuindo para isso tecnológica, cultural e socialmente.

\section{1}

\section{A convergência e a ubiquidade da comunicação nas relações: um novo olhar para a criação de conteúdos interativos digitais}

Pensar em nossa relação no dia a dia com a tecnologia é pensar também na mudança de padrões sociais e culturais. Quando suportes hipermidiáticos, sistemas operacionais e aplicativos passam a fazer parte de nossas vidas, são estabelecidas também novas formas de pensamento para a criação de conteúdos que se apropriem desses recursos tecnológicos, transformando também o nosso comportamento e recriando as relações de comunicação. Murray discorre sobre o poder de alcance que o desenvolvimento tecnológico trouxe com a popularização dos computadores pessoais:

O computador ligado em rede atua como um telefone, ao oferecer comunicação pessoa a pessoa em tempo real; como uma televisão, ao transmitir filmes; um auditório, ao reunir grupos para palestras e discussões; uma biblioteca, ao oferecer grande número de textos de referência; um museu, em sua ordenada apresentação de informações visuais; como um quadro de avisos, um aparelho de rádio, um tabuleiro de jogos e, até mesmo, como um manuscrito, ao reinventar os rolos de textos dos pergaminhos. Todas as principais formas de representação dos

\footnotetext{
${ }^{13} \mathrm{O}$ termo "suporte hipermidiático" faz referência aos aparelhos físicos, como smartphones e tablets.
} 
primeiros cinco mil anos da história humana já foram traduzidas para o formato digital. (MURRAY, 2003, p.41).

Observamos que nos últimos 10 anos, o avanço foi tão relevante que os próprios suportes tradicionais, como a televisão, ganharam incrementos tecnológicos, possibilitando o acesso ao ambiente virtual ${ }^{14}$ e a conteúdos antes vistos apenas em computadores com acesso à internet. Da mesma forma, conteúdos antes exclusivos de computadores, hoje podem ser acessados via celular. Enfim, podemos notar que convergência dos meios torna-se um facilitador para que os conteúdos sejam cada vez mais disseminados e acessados a critério do usuário.

No ano de 2015, a venda de smartphones superou o número de desktops no mundo. Este fato, anunciado no documentário Google Mobile Day ${ }^{15}$, do Google, atualmente uma das maiores empresas de comunicação e tecnologia mundial, foi estudado sob diversos ângulos, dentre os quais o aumento de recursos tecnológicos ${ }^{16}$ que um único suporte hipermidiático pode oferecer, ampliando o seu valor de uso, e, também, o crescimento da aquisição por classes economicamente inferiores. Podemos observar, então, que o avanço tecnológico propicia não apenas o alcance de informações, mas também dá ao usuário o poder de escolha de quais conteúdos prefere acessar em determinado momento, de forma mais democrática e abrangente. Ou seja, não é mais necessário ter uma televisão para assistir conteúdos audiovisuais, um computador para navegar na internet, e um celular para fazer ligações móveis. Um smartphone ou um tablet, por exemplo, pode reunir todas essas atividades.

Essa transformação implica no conceito de ubiquidade no âmbito dos ambientes hipermídiaticos, que pressupõem a habilidade de se comunicar a qualquer hora e em qualquer lugar via aparelhos eletrônicos. Apesar de não oferecer diretamente a mobilidade, podemos considerar os suportes ubíquos tendo em mente que podemos

\footnotetext{
${ }^{14} \mathrm{O}$ uso dos termos "ambiente concreto" e "ambiente virtual" é meramente uma forma de distinguir os ambientes offline e online, respectivamente, para que a comparação entre eles seja possível de ser compreendida pelo leitor.

${ }^{15} \mathrm{https} / / / \mathrm{www}$. youtube.com/watch?v=19n9u5fo-zc

${ }^{16}$ O termo "recurso tecnológico" refere-se às atividades (ligações, mensagens, acesso aos e-mails e a aplicativos on e offline) até às interações (tanto do suporte com o usuário, como das relações de comunicação) disponíveis nos suportes hipermidiáticos.
} 
usá-los em qualquer lugar (SOUZA e SILVA, 2006, apud SANTAELLA, 2013, p.15).

Para Santaella (2013, p.17), a computação ubíqua depende da computação móvel e da pervasiva. A primeira pode ser entendida como a mobilidade física do usuário portando algum suporte hipermidiático, tornando-o onipresente e dispondo da capacidade de utilização de seus serviços, independente de sua localização. A computação pervasiva, por sua vez, dá ao suporte hipermidiático a capacidade de localizar o usuário regionalmente, obtendo e atualizando dados e informações pertinentes a ele, sem que este precise configurá-lo. Ou seja, aos poucos, o suporte torna-se "invisível" a quem o utiliza.

Essa evolução tecnológica, aplicada a suportes que cada vez mais fazem parte do nosso dia a dia, permite que os mesmos acabem sendo enxergados por nós como essenciais, pois nos trazem benefícios que antes eram derivados de diversos meios ou suportes distintos, e que levavam mais tempo para serem acessados e consumidos.

Como analisa Jenkins (2006), a convergência da comunicação pode ser entendida sob alguns aspectos como o fluxo de conteúdos acessados via suportes variados, a cooperação entre mercados e ao comportamento migratório dos públicos dos meios tradicionais de comunicação para os ambientes hipermidiáticos. Portanto, este termo, convergência, atinge não apenas o avanço tecnológico, mas, também, as transformações mercadológicas, culturais e sociais. Esse ponto de vista abrange novos tipos relações tanto na linguagem entre o usuário, o suporte e o conteúdo, estudada pelo design da informação, como no comportamento pessoal. Se antes os ambientes virtuais buscavam uma certa familiarização com o ambiente concreto para trazer mais conforto para os usuários, hoje, percebemos uma inversão de papeis.

O ambiente virtual já é parte do nosso dia a dia. A linguagem oral, gestual e espontânea usada por nós foi adaptada para esse meio. Podemos observar que as conversas online entre usuários ganharam um tom mais expressivo. Por exemplo, quando queremos comunicar que estamos rindo ou dando gargalhadas, escrevemos caracteres que representam sorrisos online (LOL - laughing out loud, tradução livre 
"rindo alto") ou fazemos uso de algum emoji ${ }^{17}$ para expressá-lo. Pois bem, notamos que o caminho contrário está ganhando força, principalmente, entre jovens. Frequentemente essas abreviações ou seu significado ganham oralidade quando conversamos pessoalmente com um amigo e pronunciamos "LOL" ou "rindo alto", em determinada situação entendida como engraçada.

Com a experiência de quem trabalha há mais de 10 anos no mercado e acompanhou a entrada de marcas, como a Nike, no meio digital no Brasil, analiso a questão dos ambientes virtual e concreto, mas no âmbito dos mercados, vemos que não cabe mais a dicotomia entre on e offline. Atualmente, a estratégia de comunicação das marcas só faz sentido se estiverem relacionadas com os diversos pontos de comunicação com seus consumidores e, por que não chamá-los também de fãs e seguidores? Aliás, esse é um outro ponto que reflete a convergência da comunicação: os termos que designavam com especificidade "consumidor" para pessoas que consumem no ambiente concreto e "usuário" e "fã/seguidor" para pessoas que consumem no ambiente virtual, com as novas relações que vem sendo estabelecidas, não fazem mais sentido. A restrição de termos parece cada vez mais ultrapassada, já que um fã pode seguir uma marca porque quer consumir seu conteúdo, podendo ou não, consumir seu produto físico e vice-versa. Isso graças a convergência da comunicação e ao crescimento das relações no ambiente virtual.

Santaella (2014) acredita que as mudanças não estão apenas nos suportes, mas também na maneira como estamos recriando as linguagens humanas. Dessa forma, passamos a pensar no que é relevante para cada público, nos preocupando primeiro com a mensagem e, depois, no como disponibilizá-la da melhor forma, dependendo do suporte. Criar conteúdo relevante e com propósito, e disponibilizá-lo de acordo com o suporte é mais importante do que focar no suporte em primeiro plano. A convergência da comunicação nos permite escolher qual, como e onde queremos consumir determinado conteúdo. Não faz mais sentido esses momentos serem delimitados, sem que seja melhor para quem os escolhe.

\footnotetext{
${ }^{17}$ De origem japonesa, os emojis são pictogramas que transmitem o significado de uma palavra ou um sentimento por uma imagem simplificada. Tornaram-se muito populares na comunicação virtual porque conseguem transmitir uma resposta ou uma intenção com apenas uma representação.
} 
Em 1996, Bill Gates já abordava essa questão no ensaio intitulado "Content is King" "18. Para ele, o avanço e a democratização dos meios hipermidiáticos mudariam a comunicação e a forma pela qual a consumimos; e seria fundamental compreendermos não só as transformações comportamentais que essa mudança traria, mas também as novas possibilidades para a criação de conteúdo tendo em vista a experiência do usuário, proporcionada pela interatividade. Apesar de o ambiente virtual ampliar o alcance de conteúdos de forma mais rápida e a custo mais baixo, não se tratava apenas disso. Mas, principalmente, da transformação da relação entre o usuário com o conteúdo, mediados pelo tipo de suporte hipermidiático e seus recursos tecnológicos (hiperlinks, vídeos, gifs, animações), que preveem também interações entre eles. Ou seja, um novo pensamento deveria nascer dessa mudança, trazendo o usuário, o conteúdo e o tipo de interação para o centro das discussões.

Sob essa ótica, também é importante estabelecer uma nova concepção para a leitura. O início da ruptura com o formato do livro impresso teve início no século XX. O avanço tecnológico possibilitou a desvinculação de sua forma material, priorizando o conteúdo em relação à forma. Com isto, estamos concebendo uma nova forma de experiência entre leitor, o conteúdo e a interação que os suportes hipermídiaticos proporcionam (TEIXEIRA, 2015, p. 21). Não se trata mais de transpor o conteúdo para o ambiente virtual, mas de como proporcionar ao leitor uma nova experiência de leitura e de apropriação de conteúdo.

E, em termos de denominação, estamos mudando a forma de significação do livro como "conjunto de folhas de papel, em branco, escritas ou impressas, soltas ou cosidas, em brochura ou encadernadas ${ }^{19}$ ". Sua ressignificação desmaterializa o objeto e traz o seu conteúdo como principal componente de definição. Ou seja, o conteúdo é o objeto principal da obra e sua forma e apresentação é relativa ao suporte pelo qual será publicado. Sob essa perspectiva, podemos considerar a vasta contribuição do campo do Design no que se refere ao desenvolvimento de projetos

\footnotetext{
${ }^{18}$ https://medium.com/@HeathEvans/content-is-king-essay-by-bill-gates-1996df74552f80d9

${ }^{19}$ https://dicionariodoaurelio.com/livro
} 
editoriais gráficos ou hipermidiáticos, tendo em vista seu caráter investigatório e interdisciplinar para colaboração deste tipo de projeto.

\section{2 \\ Narrativa interativa digital infantil bilíngue: explorando a brincadeira e a imaginação no contexto da aprendizagem}

Narrativas digitais podes ser lidas de diversas formas, dependendo de suas atualizações, tanto por parte do autor, como pela possibilidade de interferência do público nas histórias, de maneira colaborativa. Além disso, novos capítulos podem ser adicionados à história original, dando continuidade à sua narrativa. Isto sem mencionar os novos recursos, que a cada dia evoluem mais, permitindo novas formas de interação e navegação pela narrativa:

A forma de história digital que há de surgir abrangerá muitos formatos e estilos diferentes, mas será, essencialmente, uma entidade única e inconfundível. Não será um "isto" ou "aquilo" interativo, embora muito dessa forma possa ser extraído da tradição, mas uma reinvenção do próprio ato de contar histórias para o novo meio digital. (MURRAY, 2003, p. 236).

Para a construção da narrativa interativa digital infantil, deve-se levar em consideração, além do texto da história em si, as imagens e recursos tecnológicos interativos. Sendo assim, é um campo vasto para a pesquisa e criação de projetos no campo do Design em parceria com outras áreas. A narrativa com imagem e texto escrito se completam e permitem que o leitor oscile entre uma e outra para compreender a história. No livro ilustrado infantil, as imagens, o texto escrito e os elementos de design têm uma relação integrada, onde o significado do todo é maior que a soma das partes constituintes. As imagens dizem o que as palavras não dizem e vice-versa, pois os elementos isolados não são capazes de contar a história por completo (TEIXEIRA, 2015, p. 43).

Em observações no INES, nos deparamos com a dificuldade que a criança tem em se situar tanto temporalmente como socialmente. Em muitos casos, a criança surda torna-se um membro a parte de sua família, por não compartilhar da mesma forma oral de comunicação. Isso torna-se um impeditivo para que os valores socioculturais passados de pais para filho nas pequenas ações do dia a dia sejam assimilados pela criança. Este fato limita a sua interação no ambiente no qual vive e pode 
desencadear um comportamento passivo e inseguro em suas atitudes. Galvão (2012) corrobora este ponto de vista em sua pesquisa, com um grupo de alunos com deficiências motoras, sensoriais e intelectuais:

Temos percebido ao longo dos últimos 15 anos, como os atrasos, mais do que causados pela deficiência propriamente dita, são consequências ou da pouca intensidade ou da má qualidade das interações vividas pelos alunos a longo de suas vidas. E, nisso, estão implicados diversos tipos de problemas, desde a falta de informações e capacitação da família, a preconceitos, isolamento e a falta de confiança no potencial de cada um, tratamentos paternalistas que condicionam a uma atitude de passividade na solução dos próprios problemas, baixa autoestima e tantos outros problemas." (GALVÃO FILHO, 2004, p. 41-42)

A criança com surdez que é estimulada com propriedade, que interage com o mundo e com as pessoas que a cercam de forma construtiva e participativa tende a desenvolver-se de forma tão natural como qualquer outra criança. Como visto no capítulo anterior, o ato de contar histórias ajuda na contextualização de situações e na aplicação de palavras, de acordo com o seu significado em determinado contexto. As narrativas podem ajudar a transmitir valores socioculturais e, em modelos onde a criança interaja com ela, a apreensão do conteúdo possa ser potencializada.

Quando falamos a respeito da linguagem do ambiente virtual, nos deparamos com a navegação não linear que os suportes hipermidiáticos proporcionam. Mas, de fato, o nosso pensamento já usa esse tipo de lógica para construir o seu raciocínio em torno de uma ideia. Em uma conversa ou reflexão, buscamos referências em conteúdos que lemos ou assistimos, combinados com a nossa própria vivência e sentimentos, por exemplo. Sob esta ótica, parece até óbvio, que as pessoas que já nascem cercadas por uma forma de raciocínio mais próxima à própria lógica do pensamento humano, sintam-se à vontade e familiarizados com os suportes hipermídiaticos e sua constante evolução em prol de sistemas intuitivos.

Essa realidade é tão inerente à grande parte das crianças e jovens que têm a oportunidade de conviver com as novas tecnologias desde pequenos, que parece não fazer mais sentido não experimentá-las e não tomar partido de suas vantagens, também, para a aprendizagem.

No âmbito escolar, Canário critica a fórmula existente de ensino, onde professores e alunos são colocados em extremos opostos, como interlocutor e receptor de 
conteúdo, e não em uma situação onde ambos possam construir o conhecimento juntos. Sugere que é preciso reavaliar essa relação, tirando o professor da função de mediador de conteúdos didáticos, e colocando-o como ponte para a formação do caráter crítico de seus alunos. Além disso, lança o olhar sobre a escola e sua relação com a comunidade, incentivando a criação de estratégias e novos métodos para a aprendizagem, que podem incluir a tecnologia como aliada no formato de suporte, com conteúdos que façam sentido na realidade do contexto onde os agentes estão inseridos, promovendo um maior alcance da experiência escolar com o dia a dia dos alunos.

Para corroborar suas ideias, o autor apresenta seu estudo de caso realizado na zona rural de Portugal, onde criou uma rede de compartilhamento de informações entre a administração escolar, os professores, os alunos e os pais e, a partir daí relata o início da produção de conhecimento, baseado nessas experiências e em como os alunos podem transformar a sua realidade em conteúdos didáticos, construindo materiais de apoio escolar. Concluiu que ao incentivar o desenvolvimento de atividades de produção escrita pelas crianças, elas mostraram-se curiosas e criativas e foram capazes de pensar e desenvolver projetos quando se sentiam parte da construção de conhecimento e não meros receptores de conteúdos prontos. E essa experiência se mostrou efetiva quando a escola foi capaz de subverter as tradicionais relações de poder e saber (CANÁRIO, 2006, p.57).

A atividade de conteúdo pedagógico não precisa ser engessada em tarefas muito objetivas e que não estejam inseridas no contexto social no qual os agentes estejam inseridos. Quando as crianças são confrontadas com o termo "educativo", já se tornam pré-dispostas a rejeitá-la, pois têm a compreensão de que não existe diversão, logo, a atividade pode perder o seu objetivo de aprendizagem de alguma coisa (DEMENCIANO, 2008, p.10).

A forma de ensino atual no Brasil, que permanece por décadas sem mudanças efetivas, tende a não instigar as novas gerações e a não favorecer a troca de conhecimento mútua. Temos a oportunidade de usar a tecnologia em prol da discussão da ampliação das concepções pedagógicas e não meramente em uma fórmula pré-moldada, baseada apenas no cumprimento de tarefas, que não 
estimulam e não provocam a troca de saberes, como a retenção, a memorização e a repetição, que fazem parte dos paradigmas escolares tradicionais, como corrobora Galvão Filho (2012, p. 1).

Abordando a aprendizagem em um âmbito maior que o escolar, Canário acredita que não existe espaço limitado para promovê-la:

A aprendizagem corresponde, em essência, a um processo temporal e espacialmente amplo e difuso que se inscreve em outro processo, também amplo e multiforme, de socialização. Estamos, assim, na maior parte dos casos, diante de situações de aprendizagem que, ao contrário das situações de aprendizagem escolar, não foram formalizadas. Isto quer dizer que não há um programa e conteúdos pré-definidos, não obedecem a horários precisos, nem a espaços exclusivos, nem são objeto de avaliação ou de certificação. (CANÁRIO, 2006, p.26).

Para Vygotsky, a primeira forma de comunicação da criança é gestual, imaginativa e se faz apoiada em um contexto. A brincadeira ajuda no desenvolvimento e na aprendizagem infantil, pois a criança cria as relações com o mundo que a cerca, e começa a fazer associações entre objetos, sua características e o significado das palavras. A chave para a função simbólica da brincadeira está nos gestos representativos que a criança é capaz de executar. Ao amadurecer, ela começa a entender que "os objetos não só podem indicar as coisas que eles estão representando como podem, também, substituí-las" (VYGOTSKY, 1998, p. 145). Ela começa a fazer correlações entre as características físicas de um objeto em substituição por outro, por exemplo, de um carro por uma chapinha, pois ambos tem o metal como matéria-prima. Esse faz-de-conta da brincadeira encarrega a imaginação da criança de fazer relações e interpretações o tempo todo e ajuda em seu desenvolvimento, na significação dos objetos, estimulando sua cognição.

Logo, é coerente pensar que uma atividade onde a imaginação seja estimulada e a diversão seja levada em consideração tem grandes chances de ser eleita pela criança, e que as interações entre o conteúdo e o suporte hipermidiático durante o percurso da atividade são ferramentas para que a aprendizagem seja possível:

Não se percebeu que toda a brincadeira e todo jogo de entretenimento são feitos de trabalhos que são aprendidos e realizados para que a diversão aconteça. Consequentemente, não perceberam que os jogos de entretenimento são os jogos pedagógicos mais eficientes, pois promovem muitas aprendizagens da maneira mais divertida possível (DEMENCIANO, 2008, p. 13). 
Este ponto de vista corrobora com a importância do desenvolvimento de atividades prazerosas, com as quais as crianças se sintam estimuladas e instigadas a participar. No âmbito da narrativa interativa digital infantil bilíngue (LIBRAS e Português escrito) requer um estudo de temas que possam colaborar para as questões temporais e sociais, levantadas anteriormente, tipos de recursos gráficos, como ilustrações e personagens, a presença das duas línguas, como o português oral, na presença do narrador, o intérprete de LIBRAS e o Português escrito, o suporte hipermidiático para o qual será projetada e, por final e tão importante quanto as demais questões, quais recursos interativos farão parte da narrativa, para que a criança se sinta um agente da construção do conhecimento.

\section{3}

\section{Síntese dos temas abordados}

No decorrer do capítulo, analisamos como a convergência e a ubiquidade da comunicação está transformando as relações comportamentais, sociais e tecnológicas, e, cada vez mais, está fazendo parte de nossas vidas. A forma não linear de navegação a qual somos expostos diariamente por meio de suportes hipermidiáticos pode ser encarada de forma mais intuitiva a nós, justamente porque a nossa forma de pensar, imaginar e estruturar um raciocínio também opera sob esta lógica não linear.

Também abordamos em diversos momentos a relação própria entre o usuário, o suporte hipermidiático e o conteúdo, tendo a interatividade como ferramenta principal para a experiência nos ambientes virtuais. Sob este aspecto, levantamos pontos importantes para construção de narrativas interativas digitais bilíngues e como as mesmas podem auxiliar na aprendizagem de crianças surdas e ouvintes. Corroboramos a ideia de que atividades paradidáticas educativas não precisam ser engessadas e podem promover a diversão em prol da aprendizagem, promovendo a discussão entre o campo do Design e o da Educação. 


\section{Design na criação de narrativas interativas digitais bilíngues (LIBRAS e Português): estudo de caso}

Este capítulo descreve todo o processo de criação, planejamento e desenvolvimento da história interativa digital para crianças surdas e ouvintes, realizado por parte da equipe do LIDE, que tinha por seus membros a Prof. Dra. Rita Maria de Souza Couto $^{20}$, a Prof. Dra. Cristina Portugal ${ }^{21}$, pela doutoranda Ana Tereza Correia ${ }^{22}$, a Dra. Eliane Jordy ${ }^{23}$, a Mestre Natália Brunnet ${ }^{24}$ e pelos bolsistas PIBIC-CNPq Lucas Ribeiro e Guilherme Menezes. Além dos membros da equipe do LIDE, também participaram em momentos pontuais do projeto, profissionais diversos, como ilustradores, sonorizadores, narradores e programadores.

A necessidade de mergulhar neste projeto partiu da expertise dessa equipe no que diz respeito ao universo de aprendizagem de crianças surdas e do desenvolvimento de projetos anteriores com este cunho para este mesmo público. A partir de pesquisas sobre aplicativos de histórias voltados para crianças, constatamos que, apesar de muitos oferecerem mais de um ou dois idiomas, nenhum oferecia a LIBRAS como opção de idioma. A pesquisa foi ampliada aos aplicativos voltados especialmente para crianças surdas e o resultado foi muito restrito, apresentando na maioria dos casos um intérprete vestido de preto, em um canto da tela, seguindo os padrões de tradução simultânea de vários outros suportes, como programas de televisão e vídeos online. Ou seja, mesmo em um material produzido para a

\footnotetext{
${ }^{20}$ Rita Maria de Souza Couto: http://buscatextual.cnpq.br/buscatextual/visualizacv.do?id=K4784069P7

${ }^{21}$ Cristina Portugal: http://buscatextual.cnpq.br/buscatextual/visualizacv.do?id=K4758579P8

${ }^{22}$ Ana Tereza Correia: http://buscatextual.cnpq.br/buscatextual/visualizacv.do?id=K4559793Y6

${ }^{23}$ Eliane Jordy: http://buscatextual.cnpq.br/buscatextual/visualizacv.do?id=K4434910Z9

${ }^{24}$ Natália Brunnet: http://buscatextual.cnpq.br/buscatextual/visualizacv.do?id=K4713056Z9
} 
inclusão, as necessidades efetivas de comunicação da comunidade surda não eram devidamente trabalhadas nem solucionadas.

A fim de pensar em um objeto que realmente integrasse crianças surdas e ouvintes, surgiu a ideia de criar uma narrativa interativa digital, em formato de aplicativo para, incialmente, os tablets. A história ajuda a contextualizar situações e palavras comuns às duas línguas e a estabelecer relações sociais, observadas, como apontado anteriormente, como um problema em lares onde pais de crianças surdas são ouvintes. O meio digital e os suportes que proporcionam esse contato, além de serem facilitadores no processo de divulgação e distribuição, estão intimamente ligados ao contexto atual, onde muitas crianças já tem acesso, mostrando desenvoltura instintiva e investigativa. A interatividade também está associada à atualidade e à forma com a qual, progressivamente, nos comportamos no ambiente online, de forma majoritariamente colaborativa.

Para desenvolvimento do livro digital, elegeu-se a cidade do Rio de Janeiro como cenário, explorando áreas históricas da cidade. Entendemos que seria uma ótima oportunidade para abordar por meio da narrativa, questões pertinentes ao universo de cidadania das crianças surdas. Em sessões de observações no INES e em conversas com professores, entendemos que, por conta da linguagem ${ }^{25}$, a localização espacial de tempo e local pode ser mais complexa para as crianças. Dessa forma, além de aproveitarmos localmente a cidade, também poderíamos ajudar na contextualização temporal, abordando aspectos históricos de um bairro carioca.

Um dos grandes desafios do projeto foi contemplar a LIBRAS e o Português de forma complementar e incentivando que as crianças surdas e as ouvintes tivessem contato com ambas, despertando o seu interesse para as duas línguas.

\footnotetext{
${ }^{25}$ As crianças surdas geralmente tem o primeiro contato com a LIBRAS quando ingressam em uma instituição especializada de ensino. Logo, tendem a constituir a construção do pensamento apenas a partir dessa fase.
} 
Ao longo deste capítulo, abordaremos a construção da narrativa interativa digital bilíngue para crianças surdas e ouvintes como o nosso estudo de caso e descreveremos todas as partes percorridas até a finalização desta tese.

\section{1}

\section{Metodologia de desenvolvimento do projeto}

Levando-se em consideração a experiência da equipe em projetos de design voltados para crianças surdas foram definidas algumas etapas para o desenvolvimento da narrativa interativa digital. Em que pese à apresentação em etapas, o processo de pesquisa será pautado por ações realizadas concomitantemente. A figura abaixo apresenta um resumo do processo metodológico da pesquisa. A parte em azul mais claro não pôde ser concluída a tempo da conclusão desta tese, mas está sendo iniciada e a previsão de seu término em meados de 2019. 


\section{FASE 2: Fundamentação teórica}

A linguagem e a criança surda

A narrativa interativa digital

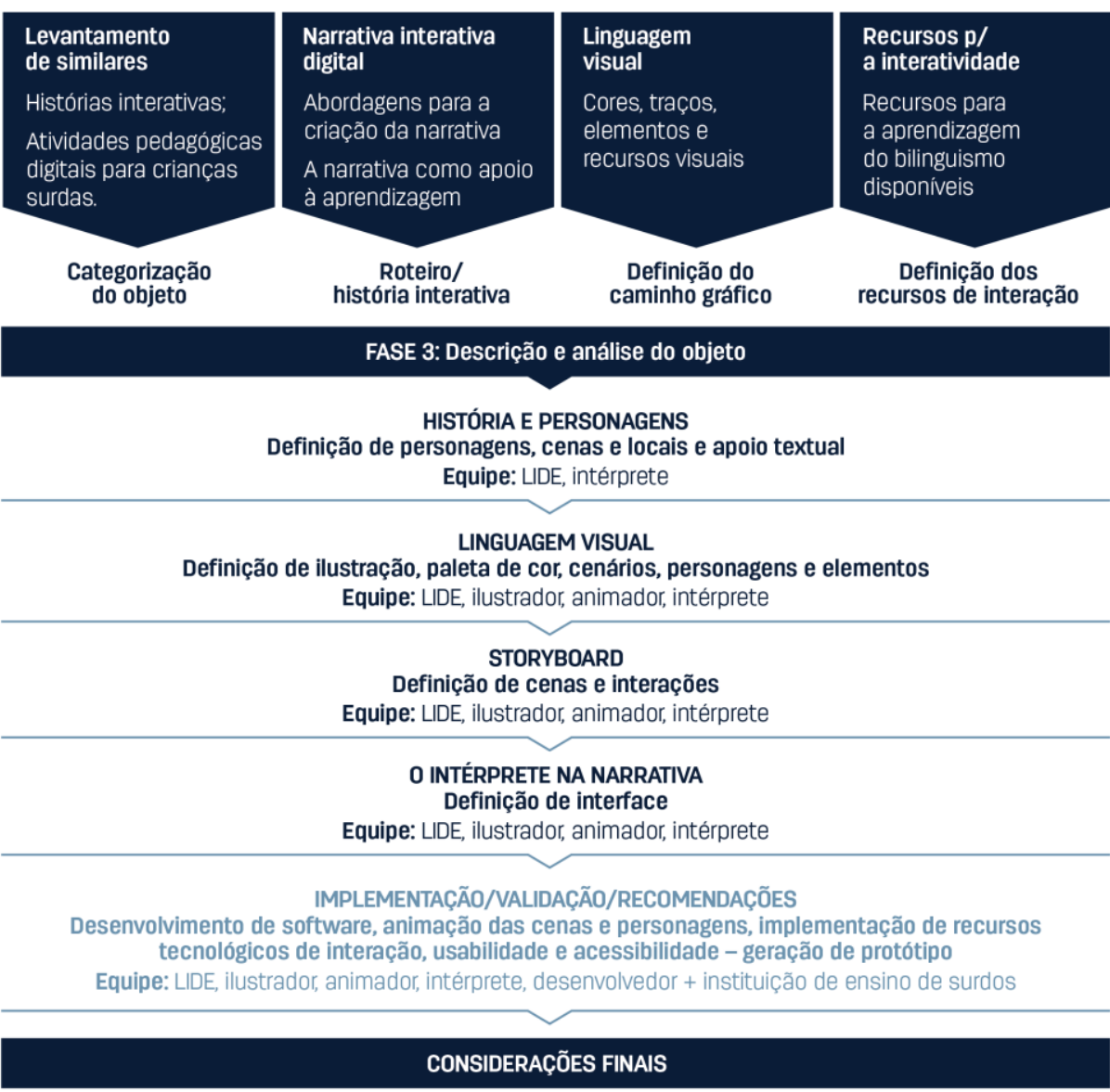

Figura 1: quadro de processo metodológico da construção da narrativa (Fonte: acervo LIDE).

\section{2}

\section{Descrição do processo de desenvolvimento do projeto}

Este subcapítulo está dividido em ordem cronológica, de acordo com etapas percorridas durante o processo de criação e desenvolvimento do estudo de caso: pesquisa de similares, construção da narrativa, criação da linguagem visual, definição das interações, convivência das duas línguas (Português escrito e a LIBRAS), desenho do storyboard e definição dos wireframes. Como apontado no subcapítulo anterior, a única etapa que ainda não foi finalizada é o desenvolvimento do protótipo. 


\subsection{1}

\section{Pesquisa de similares e análogos}

O primeiro passo para a criação da narrativa foi a pesquisa de similares e análogos. À luz do projeto, todos os membros da equipe trouxeram referências digitais e impressas de histórias e projetos gráficos que nos inspiraram.

Nossa maior referência similar é o aplicativo Fantastic Flying Books, de Mr. Morris Lessmore (app Moonbot) que, além de inspirar o projeto como um todo, também teve forte influência na ilustração. E nossos análogos são: "Pelo Rio", de Vania Strarko (ed. Pallas); "Grande Livro dos Medos", de Emily Gravett (ed. Salamandra); "Aconteceu na Escola”, de Anna Claudia Ramos e Sandra Pina (ed. Pallas). Os desenhos animados que serviram de inspiração foram Charlie Brown, de Charles M. Schulz, e Irmão do Jorel, de Juliano Enrico. Categorizamos todas os similares e análogos, criando parâmetros a serem analisados para que tivéssemos uma base objetiva. Para isso, criamos o seguinte quadro:

\begin{tabular}{|l|l|l|}
\hline Características & Atributos & Considerações \\
\hline Cor & & \\
\hline Texto x imagem & & \\
\hline Interações & & \\
\hline
\end{tabular}

Tabela 2: quadro pesquisa de similares

A cor era muito importante para nós porque indivíduos surdos tendem a ser muito impactados pela visão; a relação entre texto e imagem era crucial para definirmos o volume de massa textual e as cenas necessárias; e as interações, o nosso grande atrativo para a colaboração das crianças. 


\section{Pelo Rio}

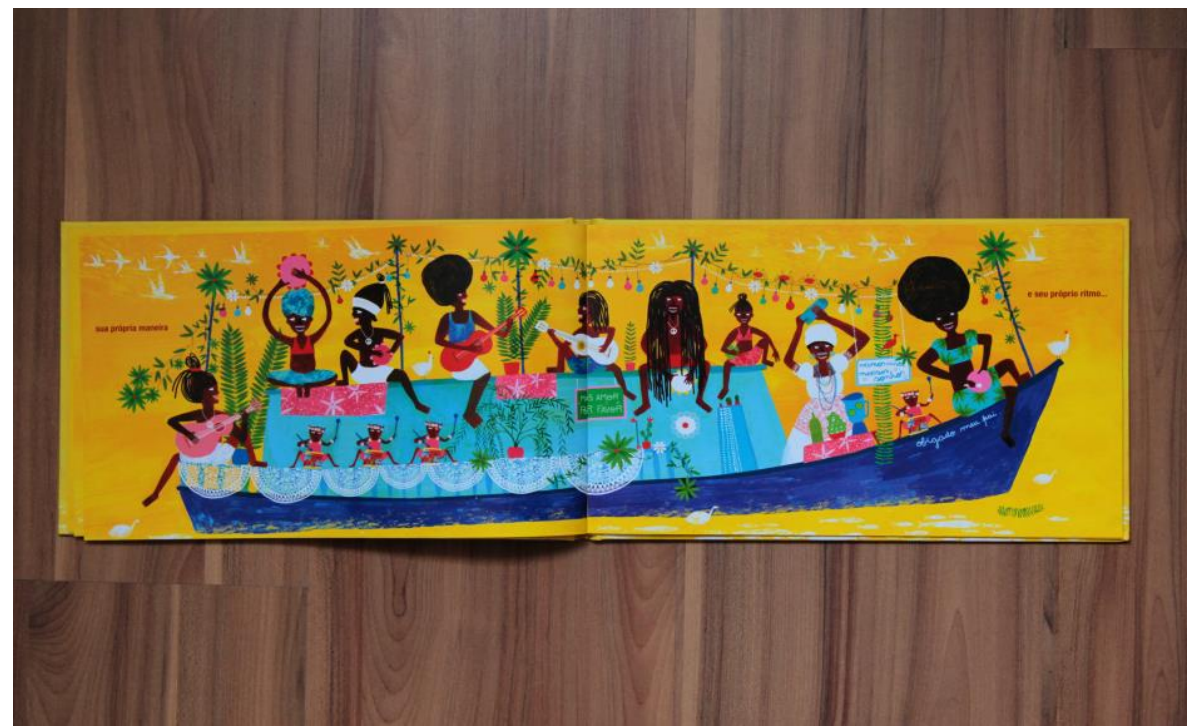

Figura 2: Análise de análogos - foto do livro Pelo Rio, Editora Pallas.

\begin{tabular}{|l|l|l|}
\hline Características & Atributos & Considerações \\
\hline Cor & $\begin{array}{l}\text { Variação de cores dentro } \\
\text { do mesmo tom }\end{array}$ & $\begin{array}{l}\text { Facilita o uso de muitas cores, } \\
\text { mantendo a identidade visual } \\
\text { do projeto }\end{array}$ \\
\hline Texto x imagem & $\begin{array}{l}\text { Texto e ilustração } \\
\text { complementares }\end{array}$ & $\begin{array}{l}\text { Possibilita a redução de massa } \\
\text { textual e a explorar mais a } \\
\text { ilustração }\end{array}$ \\
\hline Interações & Virar as páginas & \\
\hline
\end{tabular}

Tabela 3: quadro pesquisa de similares - livro Pelo Rio

O livro "Pelo Rio" nos inspirou a explorar uma paleta de cor variada, trabalhando com os tons das cores. Ao trabalhar a complementariedade entre imagem e texto, também conseguimos reduzir a massa textual da nossa história. Essa decisão foi fundamental para que texto, LIBRAS e ilustrações funcionassem de forma integrada. Assim, pudemos prever inserções parciais da LIBRAS e do Português escrito. 


\section{O Grande Livro dos Medos}

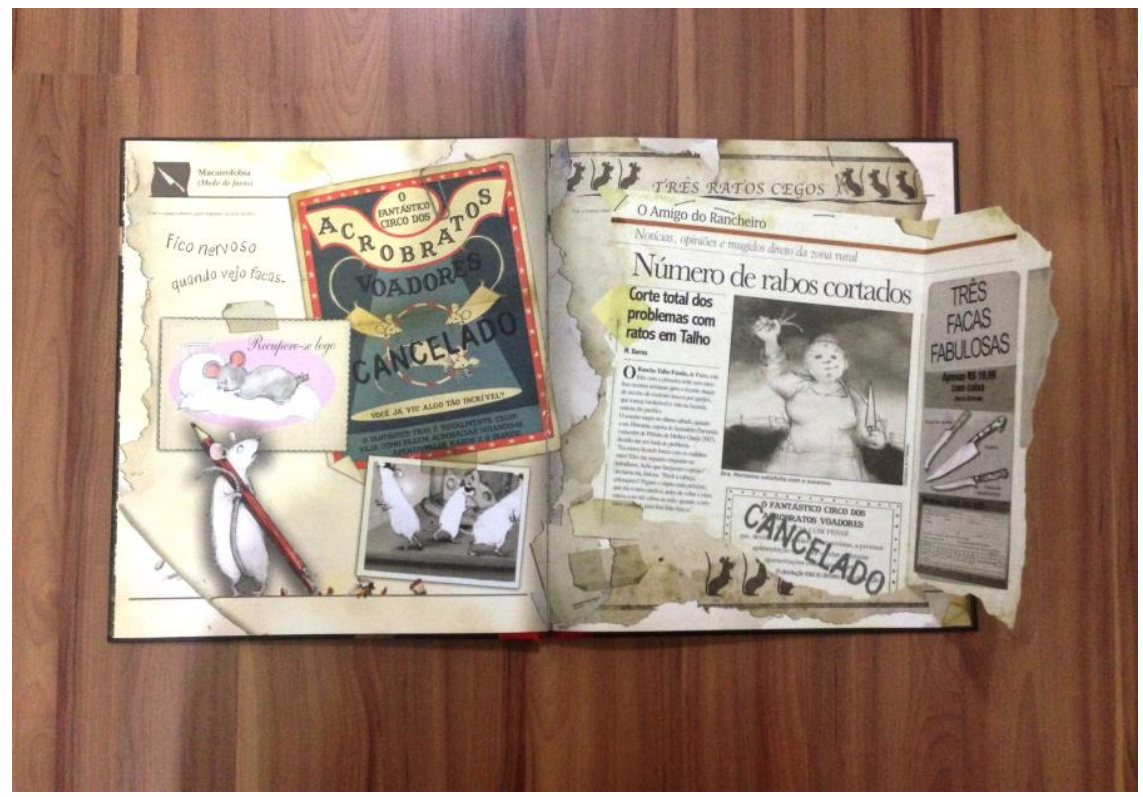

Figura 3: Análise de análogos - foto do livro Grande Livro dos Medos, Editora Salamandra.

\begin{tabular}{|c|c|c|}
\hline Características & Atributos & Considerações \\
\hline Cor & $\begin{array}{l}\text { Variação de cores dentro } \\
\text { do mesmo tom }\end{array}$ & $\begin{array}{l}\text { Facilita o uso de muitas cores, } \\
\text { mantendo a identidade visual } \\
\text { do projeto }\end{array}$ \\
\hline Texto $\mathrm{x}$ imagem & $\begin{array}{l}\text { Texto e ilustração } \\
\text { complementares }\end{array}$ & $\begin{array}{l}\text { Possibilita a redução de massa } \\
\text { textual e a explorar mais a } \\
\text { ilustração }\end{array}$ \\
\hline Interações & $\begin{array}{l}\text { Interação com páginas } \\
\text { que se desdobram e a } \\
\text { criança pode desenhar e } \\
\text { escrever }\end{array}$ & $\begin{array}{l}\text { As crianças aprendem o nome } \\
\text { científico de várias fobias e } \\
\text { interagem com o livro } \\
\text { escrevendo sobre seus medos } \\
\text { e desenhando }\end{array}$ \\
\hline
\end{tabular}

Tabela 4: quadro pesquisa de similares - Livro O Grande Livro dos Medos

Este projeto inspirou a também compartilhar conhecimento sobre elementos da história e a explorar o máximo de interação com as crianças. Como vimos anteriormente, quando crianças surdas se sentem estimuladas a participar, a tendência é se concentrarem para desempenhar a atividade. 


\section{Aconteceu na Escola}

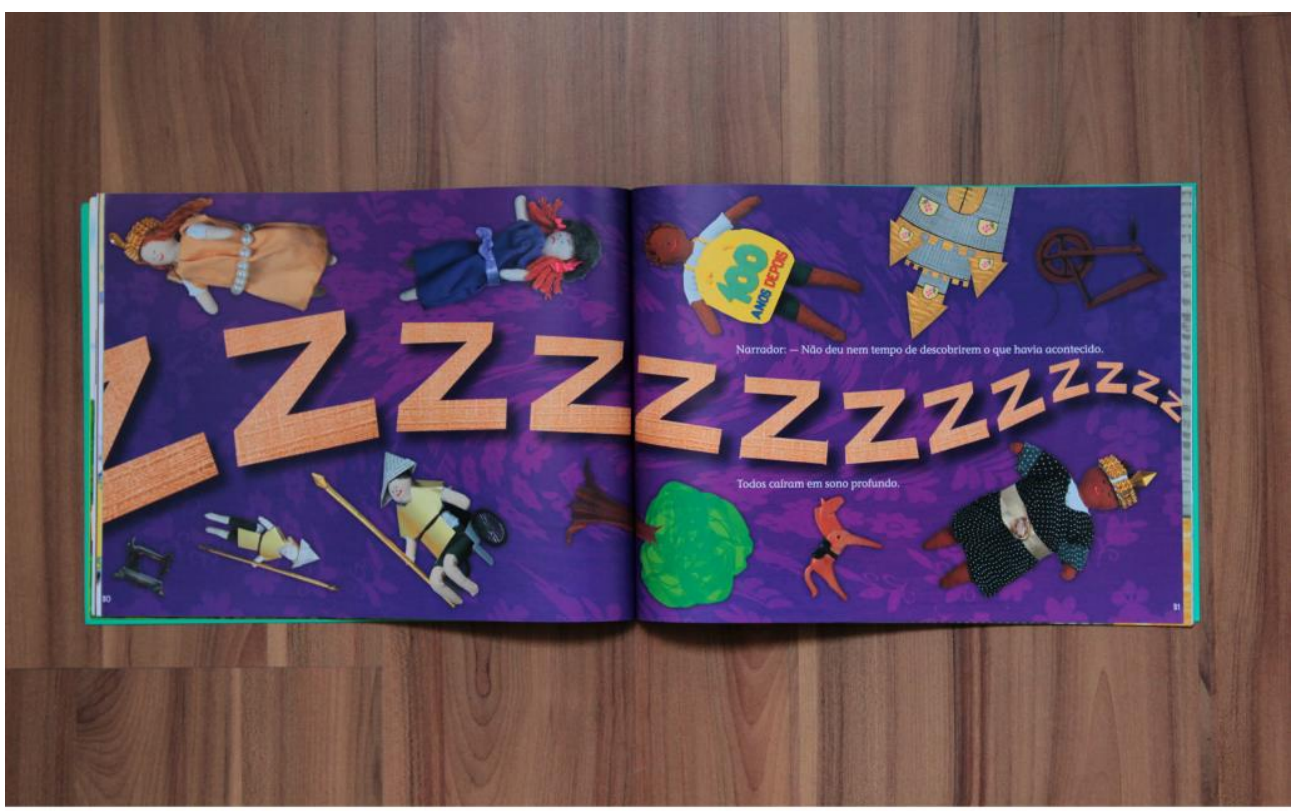

Figura 4: Análise de análogos - foto do livro Aconteceu na Escola, Editora Pallas.

\begin{tabular}{|l|l|l|}
\hline Características & Atributos & Considerações \\
\hline Cor & $\begin{array}{l}\text { Variações de cores, tons } \\
\text { e texturas }\end{array}$ & $\begin{array}{l}\text { Consegue muitas cores e } \\
\text { linguagens gráficas sem } \\
\text { perder a identidade }\end{array}$ \\
\hline Texto x imagem & $\begin{array}{l}\text { O texto vira, por muitas } \\
\text { vezes, parte da própria } \\
\text { ilustração. Também } \\
\text { trabalha a } \\
\text { complementariedade } \\
\text { entre texto e imagens }\end{array}$ & $\begin{array}{l}\text { Possibilita que o próprio texto } \\
\text { seja reinterpretado e utilizado } \\
\text { como parte da brincadeira na } \\
\text { hora da leitura }\end{array}$ \\
\hline Interações & & \\
\hline
\end{tabular}

Tabela 5: quadro pesquisa de similares - Aconteceu na Escola

A variação de linguagens, representadas por colagens, modelagens em massinha, vetores, pinturas, entre outras, nos ajudou a definir proporções de tela e o uso simultâneo da ilustração (cenários e personagens) com o intérprete de LIBRAS (vídeo real). 


\section{Fantastic Flying Books}

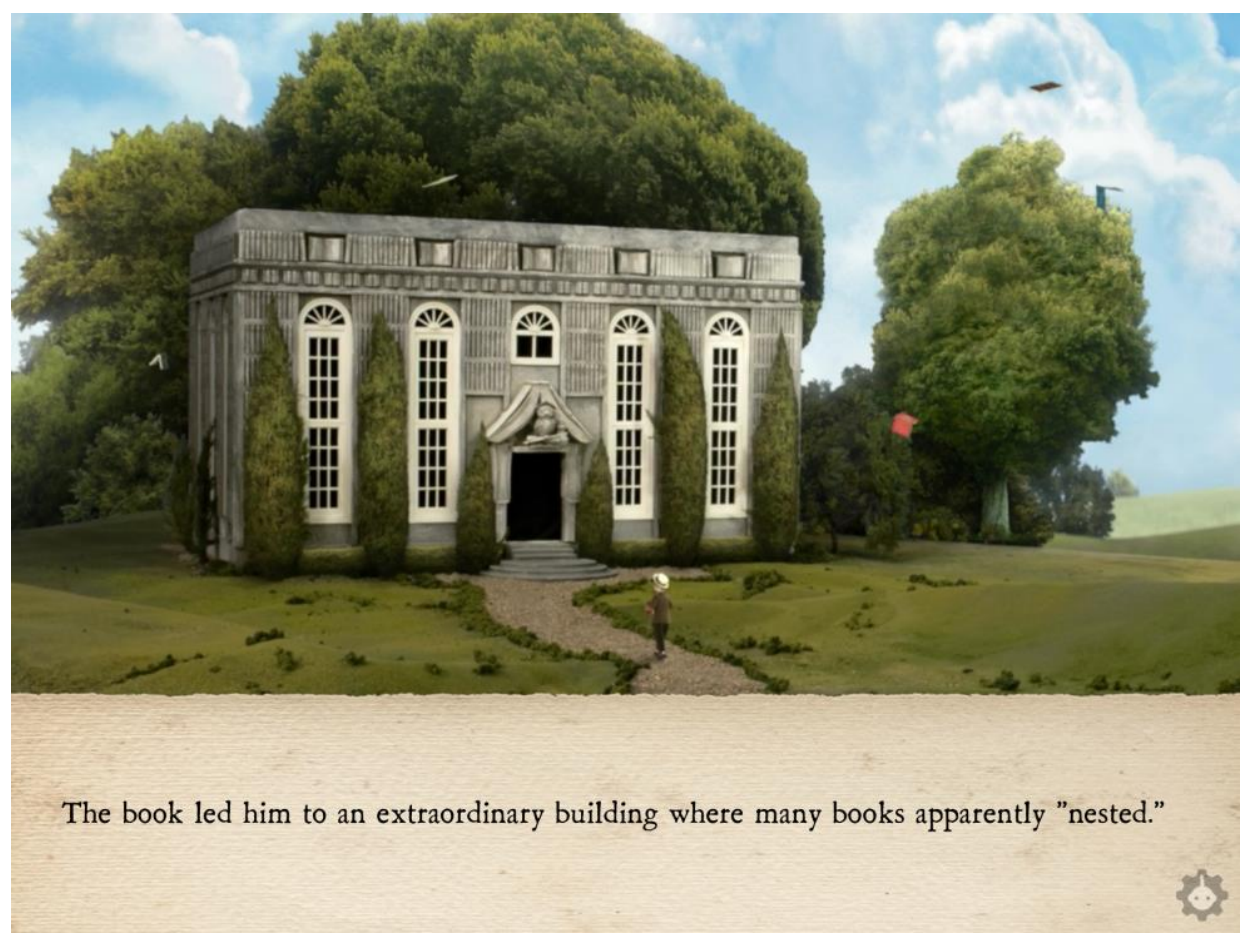

Figura 5: Análise de análogos - captura de tela do aplicativo Fantastic Flying Books, aplicativo MoonBot.

\begin{tabular}{|l|l|l|}
\hline Características & Atributos & Considerações \\
\hline Cor & $\begin{array}{l}\text { Variação de cores dentro } \\
\text { do mesmo tom. }\end{array}$ & $\begin{array}{l}\text { Facilita o uso de muitas cores, } \\
\text { mantendo a identidade visual } \\
\text { do projeto }\end{array}$ \\
\hline Texto x imagem & $\begin{array}{l}\text { Texto e ilustração } \\
\text { complementares }\end{array}$ & $\begin{array}{l}\text { Possibilita a redução de massa } \\
\text { textual e a explorar mais a } \\
\text { ilustração }\end{array}$ \\
\hline Interações & $\begin{array}{l}\text { Tem no mínimo 1 } \\
\text { interação por cena. Para } \\
\text { passar as páginas, as } \\
\text { crianças também } \\
\text { "foleiam" o livro. Há } \\
\text { interações que acontecem } \\
\text { na tela toda, saindo } \\
\text { totalmente do cenário. }\end{array}$ & $\begin{array}{l}\text { Sempre que há alguma } \\
\text { possível interação, existe um } \\
\text { recurso visual que tentar } \\
\text { estimular o toque na tela. }\end{array}$ \\
\hline
\end{tabular}

Tabela 6: quadro pesquisa de similares - Aplicativo Flying Books

O aplicativo "Fantastic Flying Books" inspirou o início deste projeto por sua riqueza na narrativa, ilustração, usabilidade e interações. Foi a nossa maior 
referência por já ser uma narrativa interativa digital muito bem implementada, apesar de não contemplar a língua de sinais.

\section{Charlie Brown e Irmão do Jorel}

Por seu turno, os desenhos animados "Charlie Brown" e "Irmão do Jorel" têm duas coisas em comum: o contexto da narrativa gira em torno da amizade e das relações familiares, e abordam temas e situações que são explorados de forma sutil. São dois exemplos de desenhos que podem ser vistos por crianças e adultos e ambos farão leituras distintas sobre o seu conteúdo.

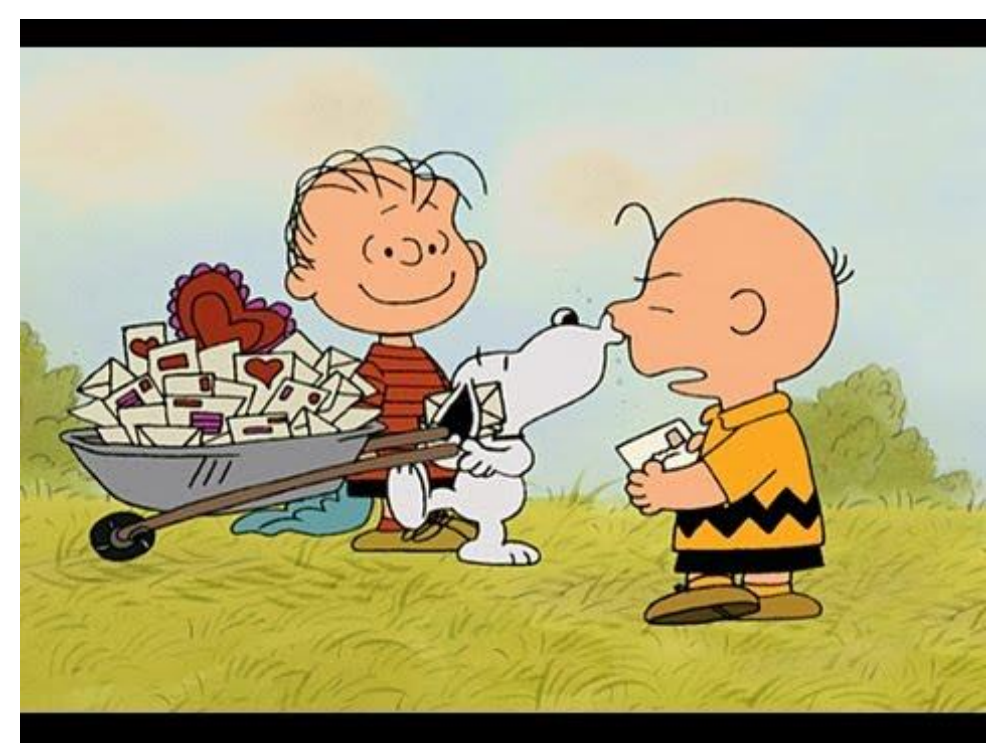

Figura 6: Análise de análogos - imagem de internet do desenho animado para a TV Charlie Brown.

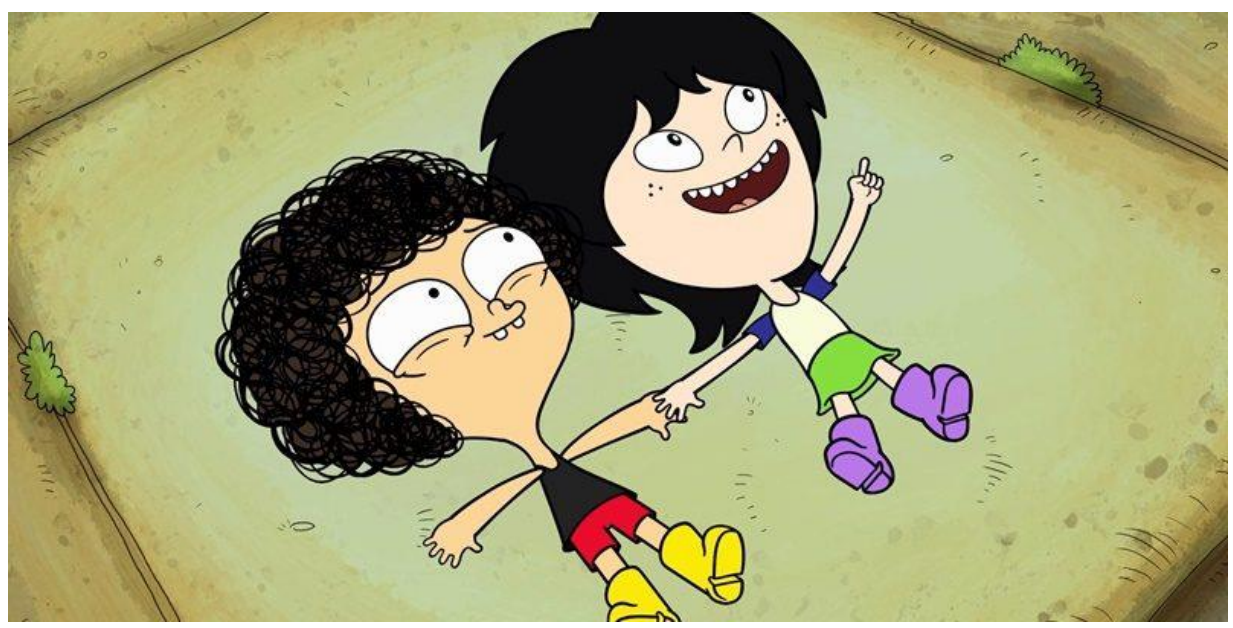

Figura 7: Análise de análogos - imagem de internet do desenho animado para a TV Doug. 


\subsection{2}

\section{A narrativa}

A construção e o desenvolvimento de narrativas digitais, para Carvalho (2008), se constitui em um processo de produção textual, que assume o caráter contemporâneo dos recursos audiovisuais e tecnológicos capazes de modernizar 'o contar histórias', podendo tornar-se uma ferramenta pedagógica eficiente e motivadora ao aluno, ao mesmo tempo em que agrega à prática docente o viés da inserção da realidade tão cobrada em práticas educativas. (Carvalho, 2008 p. 87). Oliveira (2009) acrescenta que a criança ao entrar em contato com a obra literária desde muito cedo terá uma compreensão muito maior de si e do outro, tendo a oportunidade de desenvolver seu potencial criativo e ampliar seus horizontes da cultura e do conhecimento. Dessa maneira, sua visão será melhor em relação ao mundo e da realidade que a cerca.

A narrativa digital do presente estudo prioriza o uso de imagens para apresentar a história. Toma-se por base os preceitos de Teixeira (2015) para a construção da narrativa interativa digital infantil, que deve levar em consideração, além do texto da história em si, as imagens e recursos tecnológicos interativos. Sendo assim, é um campo vasto para a pesquisa e criação de projetos no campo do Design em parceria com outras áreas. A narrativa com imagem e com texto escrito se completam e permitem que o leitor oscile entre uma e outra para compreender a história. No livro ilustrado infantil, as imagens, o texto escrito e os elementos de design têm uma relação integrada, onde o significado do todo é maior que a soma das partes constituintes. As imagens dizem o que as palavras não dizem e vice-versa, pois os elementos isolados não são capazes de contar a história por completo (TEIXEIRA, 2015 , p. 43).

Um fator relevante é a simplicidade da navegação e a busca de reações intuitivas dos usuários. Não é mais necessário um manual de instruções, já que caminhamos para uma era onde esses dispositivos funcionam como uma extensão de nossas atividades e de nossa comunicação. Além disso, escolhemos como e com qual frequência queremos receber as informações e definimos qual será o nosso percurso na navegação para alcançarmos nosso objetivo. Durante esse caminho, podemos, ainda, mudar de ideia e rapidamente alterar o tema de nosso interesse/busca. O 
nosso raciocínio agora tem ferramentas para executar a multilinearidade na navegação.

Para tomar partido sobre as nossas escolhas, primeiro categorizamos o nosso objeto. Os primeiros esboços foram feitos considerando os principais elementos da história, a saber: Personagens, Lugar, Tempo, Eventos. ${ }^{26}$

Personagens: quem é quem na história?

A história conta com dois personagens principais, Ana, com 8 anos, e José, com 7 anos. Ana é ouvinte e José, surdo. Essa amizade será abordada em cima das semelhanças e diferenças que toda amizade tem. Apresentaremos seus avós e abordaremos personagens antigos da história do Rio de Janeiro. Tanto os avós como esses personagens não são nomeados e apenas participam como apoio no desenrolar da narrativa.

Lugar: onde a história acontece?

Na vila onde Ana e José nasceram e vivem, onde viveram seus antepassados, no sopé do Corcovado, na cidade e no estado do Rio de Janeiro. Além deste lugar físico onde os personagens se encontram, eles avistam o Largo do Boticário e lá, vivem na imaginação, o povoamento do Rio Carioca.

Tempo: quando a história acontece?

Em 2018. E, ao avistar o Largo do Boticário, somos levados a uma viagem imaginária sobre a história do Rio Carioca.

Eventos: o que acontece na história que permite que os personagens resolvam problemas?

Primeiro, em nenhum momento será mencionado que Ana é ouvinte e José é surdo. Contaremos que seus antepassados viveram na vila onde hoje eles vivem e mostraremos diferenças e similaridades de gosto desses dois amigos. No desenrolar da história, haverá uma cena onde Ana ajuda José, deixando implícito que ele é surdo. Queremos reforçar que a questão da fala oral ou gestual não é

\footnotetext{
${ }^{26}$ Disponível em http://www.homeofbob.com/literature/genre/fiction/ficElmnts.html Acesso em 02 de janeiro de 2017.
} 
impeditivo para amizades se formarem. Depois, Ana e José embarcam numa aventura imaginária no Largo do Boticário, onde aprendemos a origem do nome Carioca, as espécies nativas da fauna e flora local.

Como abordado anteriormente, a escolha do tema da história teve relação com critérios que pudessem contextualizar historicamente o Rio de Janeiro, em um bairro antigo da cidade. Por esse motivo, escolhemos o Largo do Boticário, situado no Largo do Machado. Além de preservar casarões do século 1919, o bairro é cercado por uma vegetação vasta e característica da cidade e abriga uma parte do Rio Carioca, antiga fonte de água potável utilizada pelos índios Tamoios e colonizadores da região.

A narrativa se desenrola abordando relações e questões tais como, a família, a passagem de tempo, semelhanças e diferenças entre os amigos. A questão da surdez é tratada sutilmente como um pequeno detalhe, percebido em uma das cenas. A narrativa inclui, ainda, alguns fatos históricos sobre o Largo do Boticário no passado, seus personagens históricos, a fauna e a flora e a história do Rio Carioca, que deu nome aos cidadãos nascidos na cidade do Rio de Janeiro, segundo alguns historiadores.

Inicialmente, a história foi escrita em muitas laudas. A análise da narrativa a ser desenvolvida em duas línguas da forma como seriam expostas às crianças, foram mantidos apenas trechos das passagens das cenas, onde ocorre o uso do Português escrito e do narrado, e da LIBRAS, apresentados simultaneamente, apoiados pelas animações.

A criação da primeira versão do texto é de autoria de Eliane Jordy e sua adaptação aos requisitos do livro foi realizada pela equipe do LIDE. A seguir, a versão completa da história e, na sequência, sua decupagem:

\section{Versão inicial da história}

Título: Ana e José: uma história sobre amizade

Ana e José são os personagens desta história. Amigos desde bem pequenos, eles possuem muitas coisas em comum, como gostar de brincar o jogo de sete pedras, 
também chamado de sete marias. Além disso, eles amam fazer expedições, nome dado aos passeios por Laranjeiras, bairro onde vivem e, um dia também viveram suas bisavós e bisavôs. Neste lugar eles passaram muitos outonos, vários invernos, primaveras e verões.

Entre tantas coisas que possuem em comum, há aquelas que os diferem como a cor de cabelo, pele e olhos. Fora o fato de Ana ter nascido ouvinte e José, surdo, mas isso não teve importância diante da amizade da menina Ana e do menino José.

O afeto que selava a amizade com Ana, como um elo genuíno, fez com que desde muito cedo eles se comunicassem através de uma língua natural. José aprendeu libras na escola, isso fez com que a menina tivesse vontade de aprender para conversar com José.

A menina e o menino moravam bem perto um do outro, bem no sopé do morro do corcovado, a porta da casa de um, ficava ao lado da porta da casa do outro. Por isso eles passavam horas conversando sobre diversos assuntos: sobre a origem das coisas; se o Curupira era o protetor mais astuto e lendário das matas; se o bicho que avistaram era um dugongo. É bem verdade que isso seria impossível, já que o dugongo é um mamífero marinho, herbívoro, que vive no oceano índico, e está em vias de extinção.

José e Ana tinham por hábito subir no telhado para ver a chuva se formar. E toda vez que ameaçava chover era a mesma coisa... os dois corriam e se encontravam no sótão, que ficava no andar mais alto da casa de Ana, de lá subiam para o telhado. Foi assim que eles descobriram o lugar que chamavam de pátio interior. Tratava-se de um pequeno largo, escondido no alto de Laranjeiras. Ana e José ainda não sabiam, mas aquele largo se chamava Largo do Boticário, e ganhou esse nome em homenagem ao boticário da família real que morou em uma fazenda ali perto. Na época, por volta de 1879, boticário era o equivalente ao que hoje chamamos de farmacêutico. O largo era sempre visitado pelo Imperador D. Pedro II quando passeava a cavalo pelas florestas do Corcovado. Nesse largo tem um rio, o único que tinha água potável que abastecia a cidade. Os índios Tamoios quando aqui viveram deram-lhe o nome de Carioca, como todo aquele nascido na cidade. 
O curso do rio passava a céu aberto pelo Cosme Velho até chegar na parte mais baixa, chamada de Vale das laranjeiras. Há tempos atrás o rio foi canalizado da rua Almirante Alexandrino, em Santa Teresa, até o Centro, onde foi construído o aqueduto da Carioca - que conhecemos como Arcos da Lapa-através do aqueduto a água era levada até o Largo da Carioca.

A menina e o menino depois de avistarem o largo, planejaram uma ida, na manhã seguinte, àquele singelo lugar de calçamento de lajes de pedra, em estilo pé de moleque. O largo do boticário é um dos poucos lugares na cidade onde ainda é possível ver o Carioca passar a céu aberto. Em outros pontos, o rio que faz parte da história e identidade da cidade do Rio de Janeiro, foi canalizado em tubos subterrâneos e transformado em rede de coleta de esgoto. Nem é difícil dizer porque ele se tornou o refúgio, ambiente especial, o pátio interior, de Ana e José.

\section{Versão final da história}

\section{$1^{a}$ cena}

Nas encostas do Corcovado vivem Ana e José.

\section{$2^{a}$ cena}

Ana e José tem muitas coisas em comum, e possuem diferenças também.

\section{$3^{a}$ cena}

A menina e o menino vivem no lugar que vivem seus avós e, um dia, viveram seus bisavós.

\section{$4^{a}$ cena}

Como são amigos desde bem pequenos, Ana e José ali passaram muitos outonos.

\section{$5^{a}$ cena}

Vários invernos.

\section{$\sigma^{a}$ cena}

Primaveras 


\section{$7^{a}$ cena}

Everões.

\section{$8^{\circ}$ cena}

Após cada chuva de verão, a menina e o menino, tinham por hábito se encontrar no sótão... no andar mais alto da casa de Ana.

\section{$9^{a}$ cena}

Foi de lá que eles um dia avistaram um largo com casas antigas. Era o Largo do Boticário.

\section{$10^{a}$ cena}

Pelo Largo do Boticário passa o Rio Carioca. O nome do rio o dado pelo Índios Tamoios.

\section{$11^{a}$ cena}

As pessoas que viviam no Rio de Janeiro naquela época bebiam a água do rio Carioca. E é por isso que chamamos de carioca quem nasce nesta cidade.

\section{$12^{a}$ cena}

O Rio Carioca passava a céu aberto por todo Cosme Velho até chegar na parte mais baixa, chamada de Vale das Laranjeiras.

\section{$13^{a}$ cena}

A menina e o menino, curiosos para conhecer ainda mais a história de seu bairro, já planejam a próxima aventura: Uma ida ao Largo do Boticário. 


\subsection{3 \\ llustração: cenários e personagens}

Com base na pesquisa de similares sobre paleta de cor e no tema da história, que permeia por dias atuais e resgata em dado momento uma cena com base na história, entrevistamos e analisamos alguns ilustradores com traços bem diferentes. Precisávamos de mais dramaticidade à história, trabalhar de forma mais elaborada com a luz e as sombras nas cenas.

Depois de um processo de amadurecimento em relação à estética desejada pela equipe do LIDE, encontramos o caminho gráfico para ilustrar a nossa história nos desenhos de João Ricardo Madeira da Costa e Pablo Henrique Cavalcanti. Ao longo desse subcapítulo, apresentaremos os personagens e cenários desenvolvidos por ambos ilustradores.

\section{Definição das características das personagens}

Definimos que Ana e José, além do gênero, teriam características físicas diferentes para representar a diversidade da etnia brasileira. Ana seria ouvinte, negra. José, surdo, com a pele mais clara e cabelos castanhos. Não seguimos fielmente as proporções humanas por se tratar de uma história para crianças e entender que essa licença poética é uma ferramenta usual na construção de diversas produções literárias. 

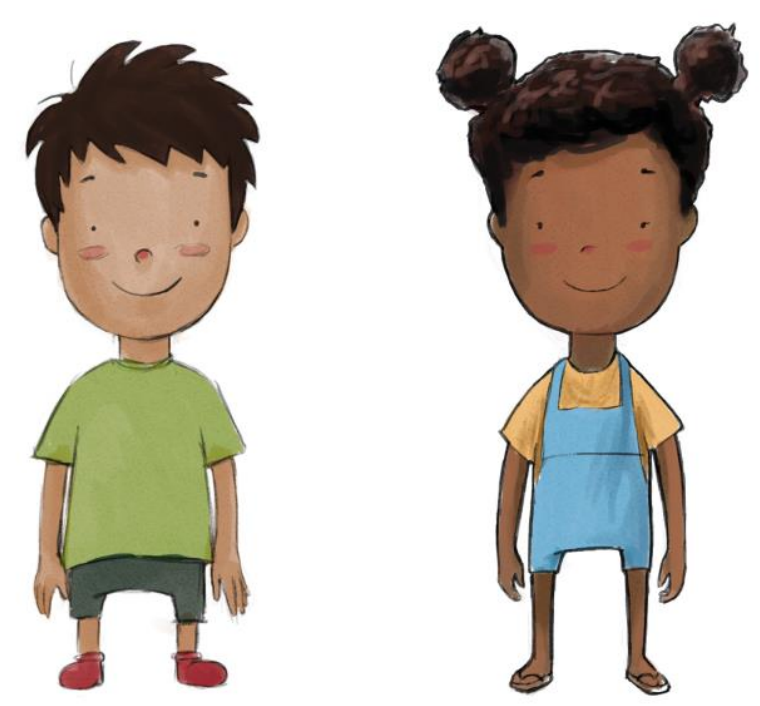

Figura 8: José e Ana, personagens da nossa história (Fonte: LIDE)

\section{Definição das características dos cenários}

A maior parte da história se passa na vila onde Ana e José moram e os cenários externos são compostos pelo Largo do Boticário e pelo Rio Carioca.

A estética proposta pelos ilustradores conta com uma paleta de cor trabalhada, em sua maior parte, nos mesmos tons e os efeitos de luz e sombra evidenciam detalhes como prédios, frutas, vegetação e a própria perspectiva dos cenários. A escolha da paleta cromática tinha por objetivo trazer a ludicidade às ilustrações e não, necessariamente, a fazer uma representação real do local. 

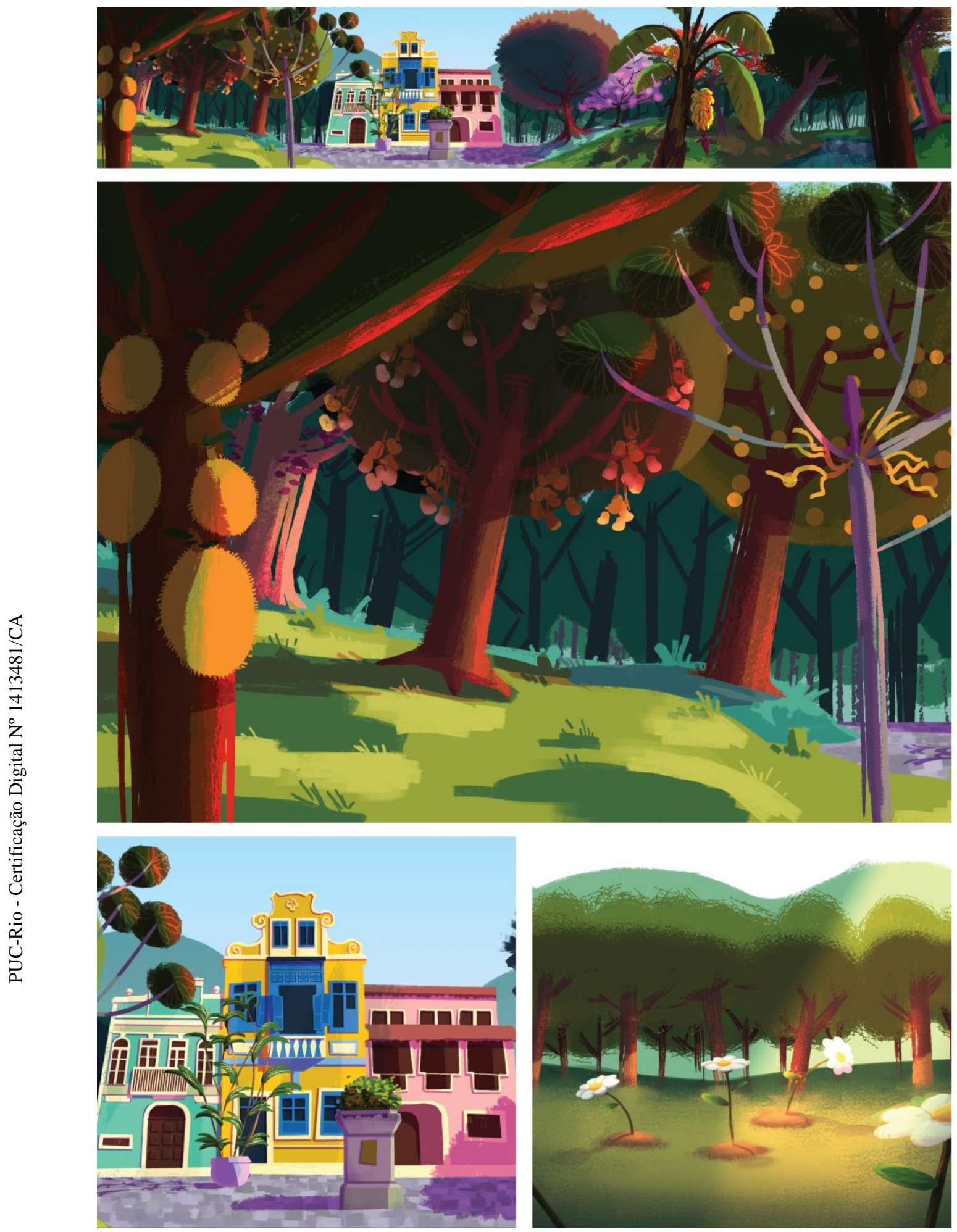

Figura 9: mosaico com ilustrações do Largo do Boticário e sua vegetação (Fonte: LIDE). 


\subsection{4}

\section{As interações}

Como abordado anteriormente, quando as crianças fazem parte do processo de construção de algo, tendem a prestar mais atenção e a se interessar pela atividade proposta. Com as crianças surdas, esse estímulo é fundamental, pois a sua condição visual é muito forte e rica. Quando são estimuladas a participar de determinada tarefa, elas se tornam parte integrante da ação e tendem a focar a atenção nos conteúdos propostos e, assim, aumentam as chances de alcance do momento de aprendizagem.

As interações nos ajudaram a trazer esse ritmo para a narrativa e funcionam como uma brincadeira a cada nova cena. O objetivo maior por trás do uso desse recurso tecnológico é o de fazer com que as crianças se divirtam interagindo com a história, como agentes fundamentais para que ela se desenrole. A intenção é somar esse recurso aos conteúdos didáticos, estimulando a aprendizagem e fazendo com que esse momento seja agradável.

Ao passar de uma cena a outra, a criança contará com uma interação diferente. A escolha de qual interação seria usada nas cenas dependeu do conteúdo de cada uma delas e dos recursos disponíveis no sistema de programação da versão de teste. A melhor fonte de pesquisa nessa etapa do projeto foram tutoriais próprios e externos ao sistema Apple.

Na definição de Bonsiepe:

Interação em sistemas operacionais refere-se ao modo de apresentar informação de maneira não linear, como hipertexto, em estrutura de nós semânticos ligados entre si (em rede), oferecendo alternativas para a navegação. Para isso, usam-se os diferentes canais de percepção (visual, auditivo, tátil) e novos procedimentos para apresentar a informação. Lidar com esses múltiplos recursos - música, imagens, animação, cinema - requer outras competências, além daquelas meramente discursivas. Isso requer trabalho de uma equipe com especialista em psicologia cognitiva, design, redação e programação. (BONSIEPE, 2011.p.87)

Para essa pesquisa mostrou-se necessário listar primeiro as interações mais primárias possíveis com o suporte escolhido para o livro: tablets. Essa lista foi encontrada no site oficial da Apple, na seção destinada aos desenvolvedores de 
aplicativos. A lista as interações mais básicas que podem ser feitas nos tablets, com suas descrições e pictogramas indicando a maneira de executá-las.

Em seguida, a pesquisa consistiu em um estudo de similares feito por meio da busca de vídeos no site Youtube. Assistindo a esses vídeos foi possível observar e listar como diversos livros digitais infantis faziam uso dessas possíveis interações proporcionadas pelo tablet, para depois, adequá-las à narrativa proposta para o livro.

A seguir, apresentamos o estudo de similares realizado para a definição das interações, cena a cena. Tal estudo serviu como uma primeira etapa de geração de ideias, inspirada nos exemplos encontrados.

$2^{a}$ Cena: Ana e José tem muitas coisas em comum, e possuem diferenças também

A segunda cena também se passa na vila. Num primeiro momento será possível interagir com as personagens enquanto colhem laranjas na laranjeira da vila, evidenciando o que elas têm em comum.

Um dos similares encontrados foi o livro "The Tale of Peter Rabbit", no qual o leitor pode, em determinada página, clicar no cenário para que frutas apareçam, possam ser movidas de lugar com o dedo e esmagadas com um aperto. Adequando esse exemplo à proposta da cena do livro em desenvolvimento, o leitor poderia clicar na árvore para que laranjas aparecessem, e como no exemplo do similar, movê-las e esmagá-las. 


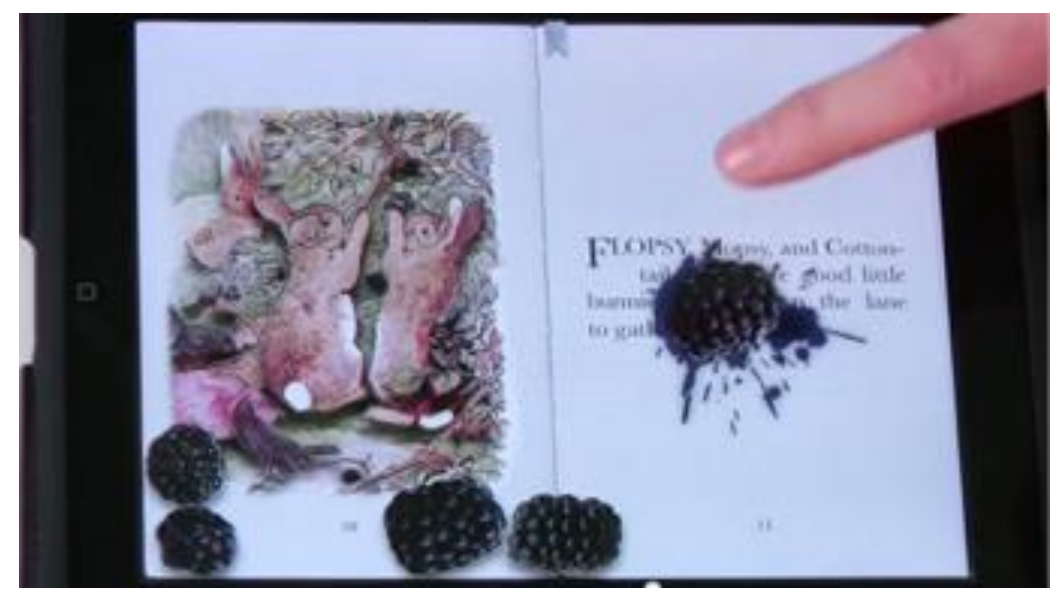

Figura 10: Análise de similares - captura de tela de vídeo-análise do livro "The Tale of Peter Rabbit" (Fonte: acervo LIDE).

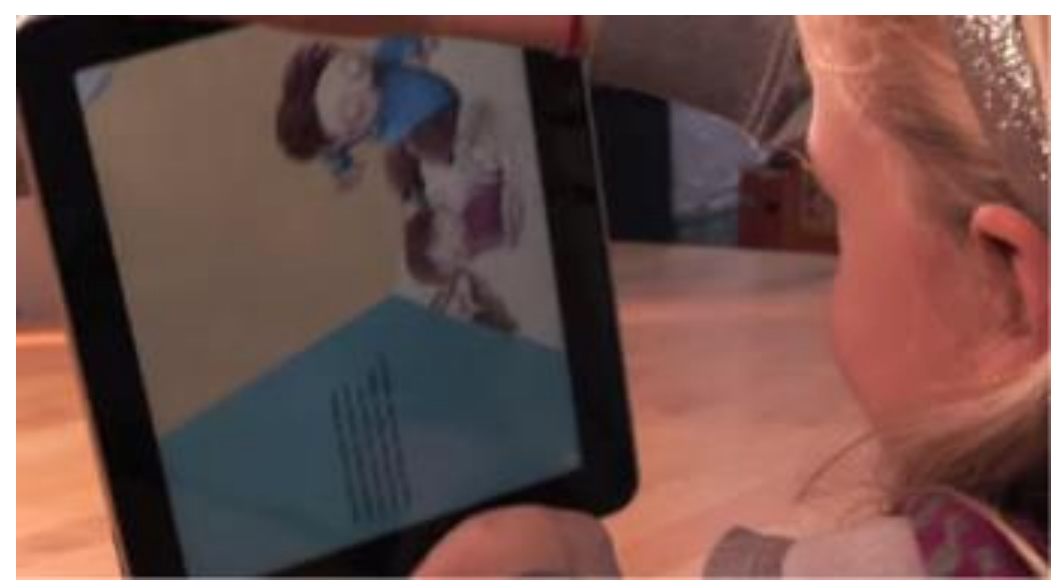

Figura 11: Análise de similares - captura tela de vídeo promocional do livro "Timo and the Magical Picture Book (Fonte: acervo LIDE).

Num segundo momento da mesma cena, para que se demonstre o que as personagens têm de diferente entre si, o usuário terá a oportunidade de interagir com as personagens enquanto elas tomam milk-shake e brincam.

No jogo "Snow Cone" o usuário tem a possibilidade de montar um sorvete de casquinha, escolhendo o tipo de cone, sabor, formato, cobertura etc. Já no jogo "Milk-shake" o usuário pode montar um milk-shake, escolhendo o copo, sabor, cobertura, canudo etc. Aplicando esses exemplos à segunda cena, o usuário poderia ter a oportunidade de montar os milk-shakes de José e Ana. 

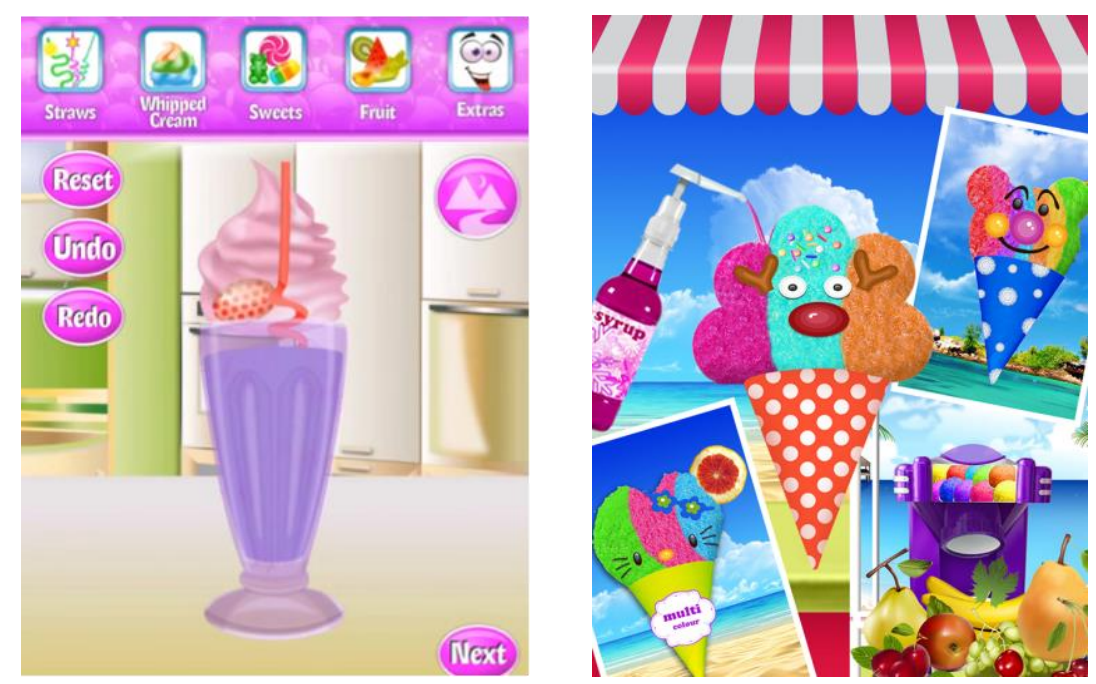

Figura 12: Análise de similares - captura de tela do jogo "Milk-shake" e do jogo "Snow Cone" (Fonte: acervo LIDE).

Nesse momento da história, por meio da interação com os avós das personagens, o leitor começará seu contato com o passado do lugar onde as personagens vivem, que se mostrará importante nos parágrafos posteriores do livro.

Na pesquisa de similares encontrou-se o livro "Floksiki", no qual o usuário pode revelar partes do cenário ao clicar em janelas, portas e cortinas. Usando esse exemplo, nessa cena do livro o usuário poderia clicar nas portas das casas da vila para revelar onde os avós das crianças se encontram. As portas onde não estão os avós das crianças poderiam revelar surpresas.

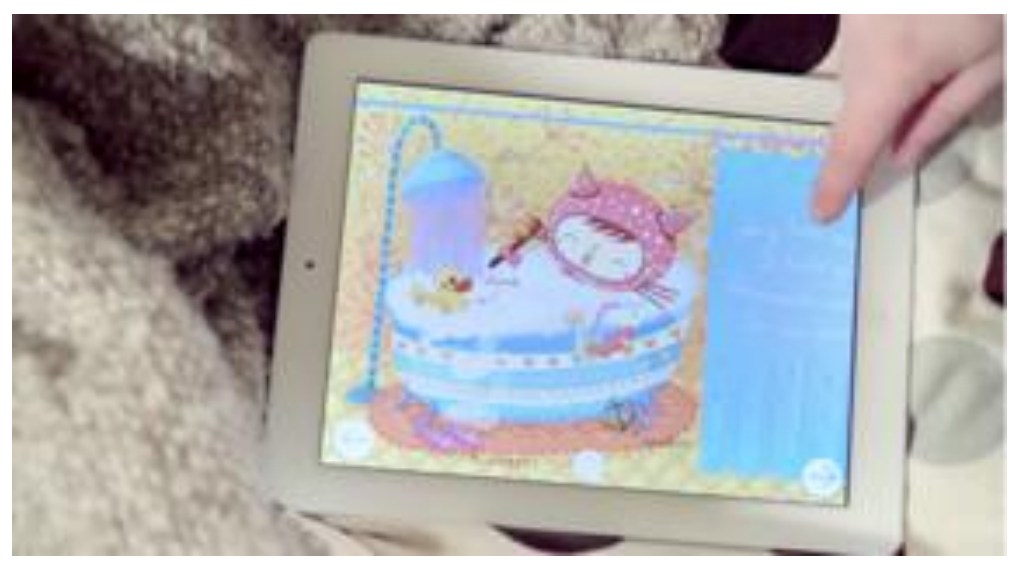

Figura 13: Análise de similares - captura de tela do vídeo promocional do livro "Floksiki" (Fonte: acervo LIDE). 
$4^{\circ}$ Cena: Como são amigos desde bem pequenos, Ana e José ali passaram muitos outonos

$\mathrm{Na}$ quarta cena as crianças estarão brincando com folhas caídas das árvores devido ao outono. Um dos similares encontrados foi o livro "Our Choice". Este livro dá a oportunidade ao usuário de assoprar o microfone do tablet, que fica abaixo ao lado do encaixe do carregador, e assim gerar uma reação no livro. Seguindo esse exemplo, nessa cena, o usuário assopraria o microfone para que as folhas das árvores voassem.

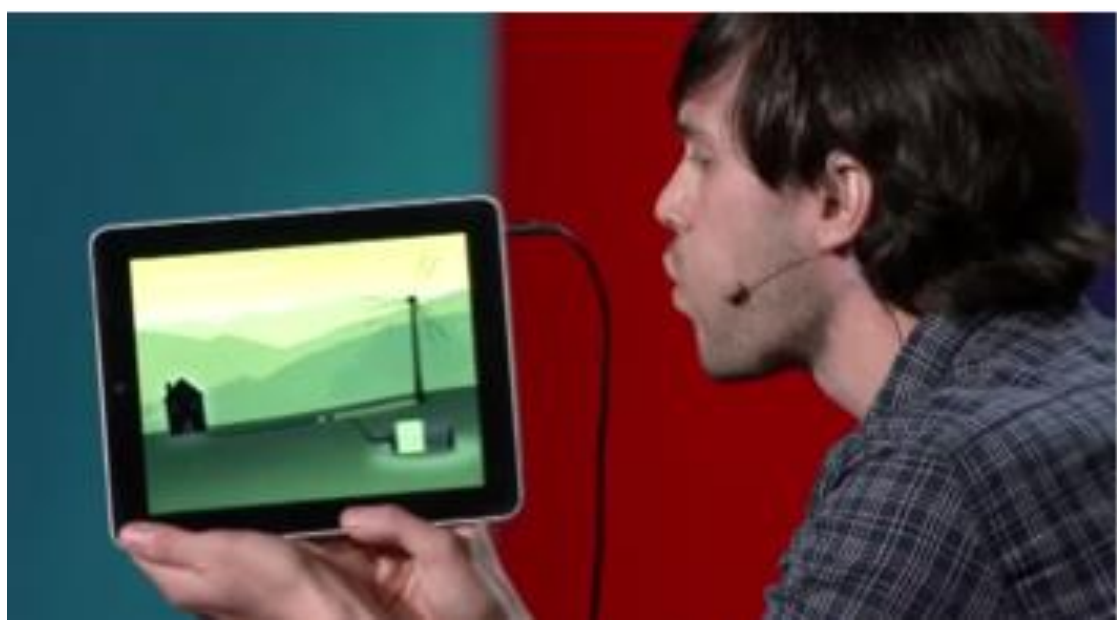

Figura 14: Análise de similares - captura de tela de uma palestra do autor do livro "Our Choice", Mike Matas (Fonte: acervo LIDE).

\section{Cena: Vários invernos"}

Nessa cena, que se passa no inverno, as personagens estarão brincando em poças por conta da chuva fina recém caída. Nesse momento o usuário poderia clicar nas poças para que os personagens pulassem nelas. Também poderia haver a possibilidade de clicar em uma poça de lama que acionaria uma tela para que o usuário pudesse desenhar na lama.

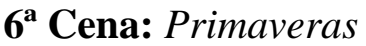

Nessa cena, o cenário estará cheio de flores e a personagem José entregará uma delas à Ana. No livro "Heart and the Bottle" o usuário tem a oportunidade, ao clicar na tela e criar flores. A partir dessa cena, pensamos que as duas personagens poderiam estar posicionadas em lados opostos e se deslocariam por um caminho 
cheio de pequenas sementes. O usuário clicaria nessas sementes para que nascessem as flores. Assim que o caminho fosse completado com as flores, José o percorreria e daria a última flor à Ana.

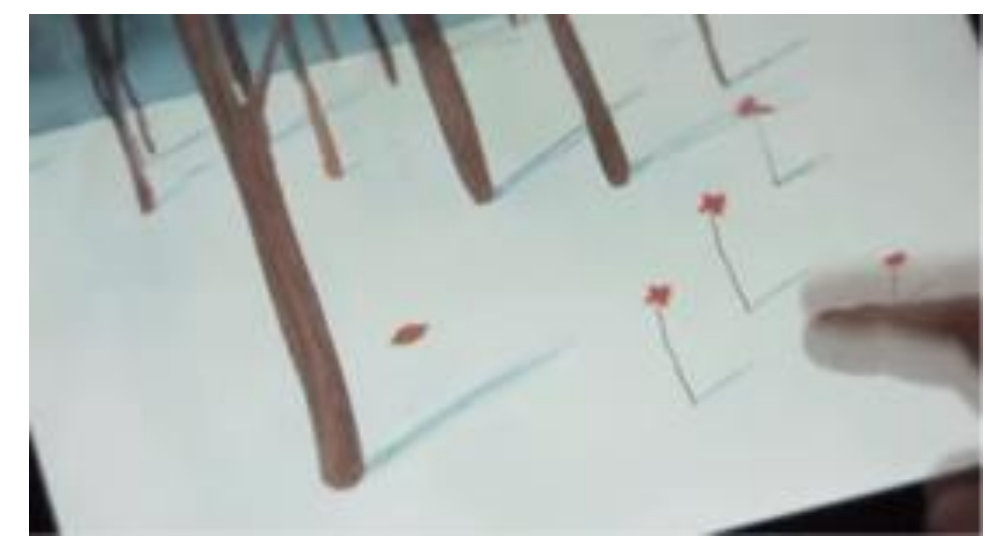

Figura 15: Análise de similares - captura de tela de vídeo promocional do livro "Heart and the Bottle" (Fonte: acervo LIDE).

\section{$7^{\text {a }}$ Cena: E verões}

Nesse momento as crianças estarão brincando de pique-pega, com o brilho intenso do Sol refletindo nelas e na vila, quando começa uma chuva de verão.

Tendo em vista que chuvas de verão geralmente são grandes e carregadas, o usuário teria a oportunidade de juntar várias pequenas nuvens brancas, que quando se juntam ficariam maiores, até virarem uma grande nuvem cinza que iniciará a chuva de verão. Enquanto chove, o usuário também poderia clicar nas crianças para que elas brinquem de pique-pega. Ao clicar em José, ele corre atrás da Ana, ao clicar em Ana, ela corre atrás do José.

Para essa cena não foram encontrados similares.

$8^{a}$ Cena: Após cada chuva de verão, a menina e o menino, tinham por hábito se encontrar no sótão, no andar mais alto da casa de Ana

Nessa cena as personagens estarão na janela do sótão da casa de Ana, olhando para fora, vendo os raios de sol. Neste momento por meio do toque do usuário, é possível um zoom no Largo do Boticário, que pode ser visto através da janela do sótão de Ana.

Para essa cena não foram encontrados similares. 
9 a Cena: Foi de lá que eles um dia avistaram um largo com casas antigas. Era o Largo do Boticário.

Após o zoom dado na interação anterior, o usuário teria a oportunidade de dar swipe (arrastar, neste caso, para o lado) na paisagem para revelar outras áreas do Largo. Uma borboleta guiaria o usuário no começo dessa interação. $\mathrm{O}$ papel da borboleta seria mostrar para o usuário que há mais conteúdo a ser revelado à direita da paisagem.

Esta borboleta sairia de um arbusto e voaria para a direita. Ao chegar no canto da tela, a borboleta ficaria voando em círculos, enquanto esperava que o usuário arrastasse o cenário para ela continuar voando.

Quando o usuário completasse essa ação, um gambá sairia por detrás de uma árvore qualquer e correria de volta para o centro da paisagem, evidenciando que o usuário também teria a oportunidade de voltar com o cenário.

Por todo cenário existiriam árvores como bananeira, mangueira, jaqueira, laranjeira e outros elementos que possibilitariam algum tipo de interação. Ao clicar na fruta, ocorreria um zoom in para a copa de uma bananeira, por exemplo. Nesse momento, o intérprete entraria ao lado falando a palavra "banana" em LIBRAS e a palavra apareceria escrita, letra a letra, como num jogo de forca.

Para essa cena não foram encontrados similares.

10 Cena: Pelo Largo do Boticário passa o Rio Carioca. O nome do rio fio dado pelo Índios Tamoios

Nesse momento uma nova tela apareceria, revelando um jogo, onde o usuário deveria juntar cartas com as letra da palavra "carioca". As quatro primeiras letras (CARI) estariam em uma cor, e as três ultimas (OCA) em outra. Assim além de tornar o jogo mais intuitivo para crianças menores, as cores evidenciariam a estrutura etimológica da palavra, abrindo uma deixa para a animação explicando o porquê do significado do nome.

Para essa cena não foram encontrados similares. 


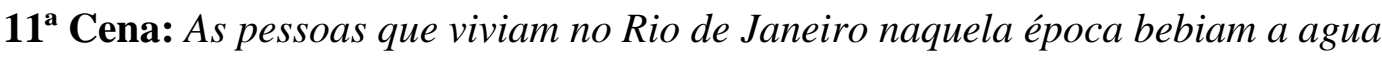
do rio Carioca. E é por isso que chamamos de carioca quem nasce nesta cidade

O usuário nessa cena, ao clicar em qualquer um dos personagens próximos ao rio, faria com que o mesmo se direcionasse para beber água.

Para essa cena não foram encontrados similares.

12 ${ }^{a}$ Cena: O Rio Carioca passava a céu aberto por todo Cosme Velho até chegar na parte mais baixa, chamada de Vale das Laranjeiras"

Na pesquisa de similares foi encontrado o livro “Toy Story”. Nele o usuário tem a oportunidade de colorir cenários do livros. Adequando esse exemplo à narrativa proposta, o leitor poderia colorir o cenário do Vale das Laranjeiras.

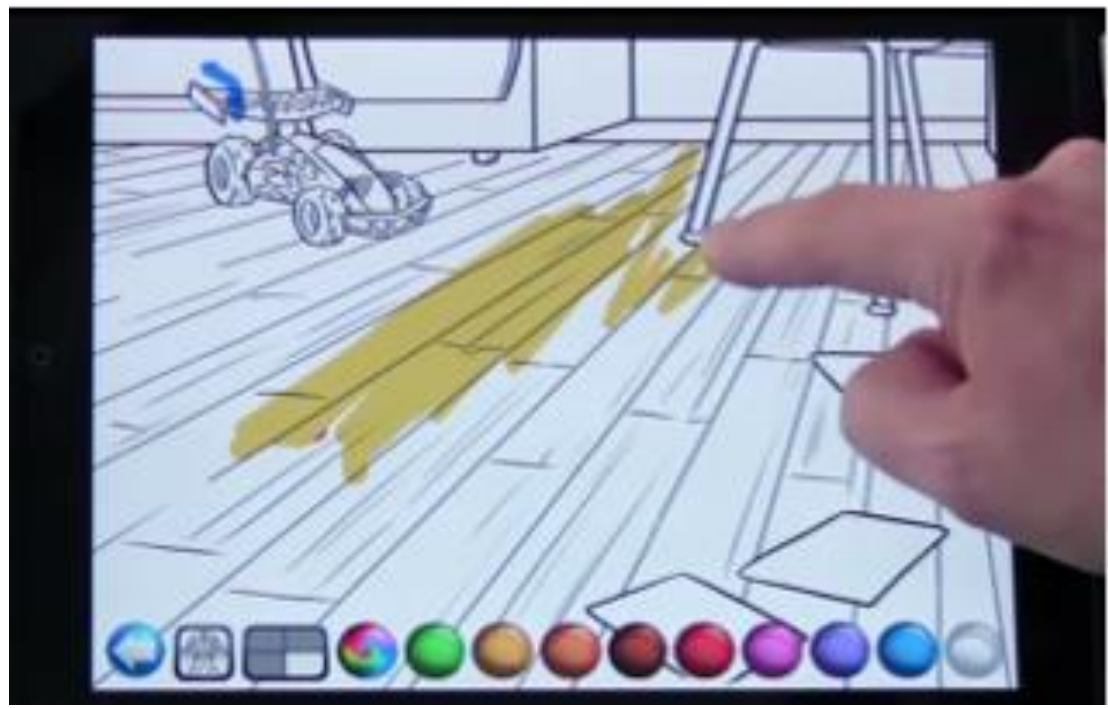

Figura 16: Análise de similares - captura de tela de vídeo-análise do livro "Toy Story" (Fonte: acervo LIDE).

$13^{a}$ Cena: A menina e o menino, curiosos para conhecer ainda mais a historia de seu bairro, já planejam a próxima aventura: Uma ida ao Largo do Boticário.

Nessa cena, as personagens Ana e José estarão conversando e um pequeno balão de sonho ligado aos dois. Dentro desse balão elas estariam vestidas com roupas de aventureiros. Nesse momento, quando o usuário clicasse no pequeno balão, revelarse-ia o sonho das crianças planejando sua próxima aventura. 
Para que a capacidade interativa, inerente aos livros digitais, fosse potencializada nesse projeto, foi imperativa a condução da pesquisa acima relatada, pois, a partir dela, foi possível realizar várias sessões de geração de ideias para se chegar à escolha das interações finais.

\subsection{5}

\section{As duas línguas na narrativa}

Utilizar a LIBRAS e o Português de forma complementar e eficaz para a compreensão da história foi um grande desafio. Primeiramente, estudamos como e onde as duas línguas seriam expostas às crianças. A ideia inicial era a de que os personagens pudessem falar em LIBRAS e tivessem dubladores para o Português, mas devido a questões complexas para representar a LIBRAS fielmente e com eficácia por meio de ilustrações e animações, tanto no estudo visual quanto na parte técnica de programação, optamos por inseri-las nas transições de cenas, com o narrador antecipando o que vem a seguir na história. Nesse caso, um narrador conta a história em Português oral, ao mesmo tempo que sua forma escrita aparece na tela, juntamente com o intérprete de LIBRAS.

Outro ponto muito importante nesta etapa do processo foi definir o perfil do intérprete. Geralmente, adultos fazem esse papel, mas como, desde o início, focamos na busca de recursos que estabelecessem maior empatia com o público alvo, chegamos à conclusão que para fazer sentido para crianças entre 7 a 12 anos, deveria ser alguém que fizesse o papel quase de um modelo, uma referência para as elas. Normalmente, nessa idade, as crianças tendem a admirar e a querer imitar adolescentes porque se projetam futuramente. A partir daí, entramos em contato com um professor do INES, Ronaldo Gonçalves de Oliveira, que participou de algumas reuniões junto com a equipe do LIDE e indicou um dos alunos da turma de teatro desta Instituição.

O INES cria e produz histórias conhecidas por crianças brasileiras, como fábulas e contos folclóricos, com atores utilizando a LIBRAS como idioma principal. Um desses atores, o adolescente de 16 anos Emanuel Carvalho, fez um teste em nosso laboratório de audiovisual e o resultado superou positivamente as nossas expectativas. Além estar na faixa etária desejada, Emanuel é surdo e um verdadeiro 
ator. Durante o processo de estudo da história para a interpretação das cenas, ele buscou dar dramaticidade a cada frase interpretada. Ou seja, em vez de meramente traduzir o conteúdo, deu vida à história com sua interpretação.

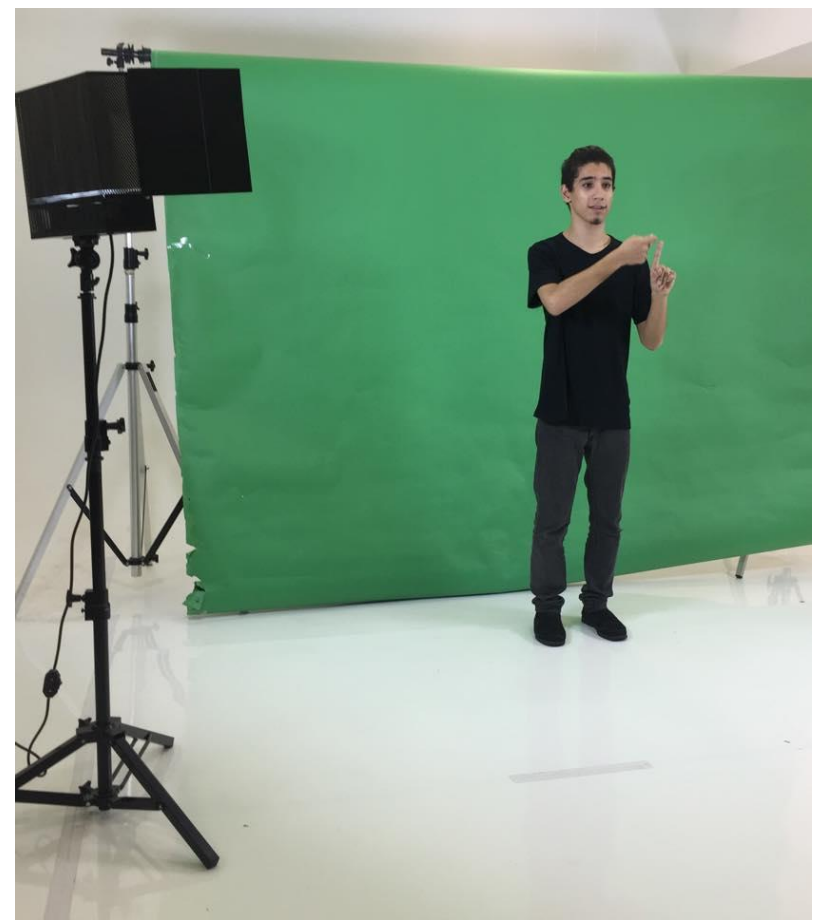

Figura 17: Emanuel no teste de interpretação, no estúdio de audiovisual do DAD/PUC-Rio (Fonte: acervo LIDE).

Ao invés do figurino preto tradicional, optamos por camisas lisas e coloridas, que compusessem com cada cena e com o cenário (aba) que será inserido na programação do aplicativo. Essa aba ocupará aproximadamente 1/3 da tela de exibição. 


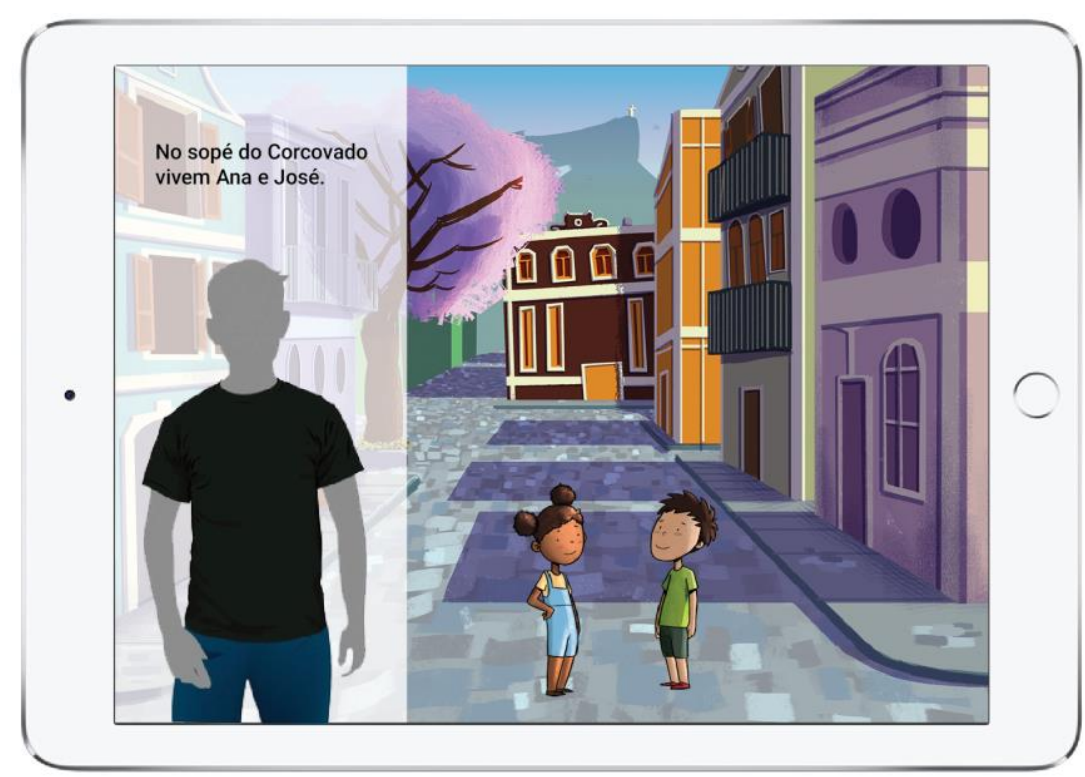

Figura 18: Teste de proporção de interface entre ilustração, intérprete e texto no aplicativo (Fonte: acervo LIDE).

\subsection{6}

\section{Storyboard}

A construção do storyboard é fundamental para guiar a equipe de ilustradores e de programação. A partir dela, é possível desenhar os personagem nos ângulos corretos, definir as perspectivas dos cenários, além de pontuar as interações e as passagens de cenas que guiarão a programação.

A construção do storyboard foi um processo longo, pois nele, além de todas as cenas, cortes e inserção das interações serem pensados, ainda consolidamos a versão final da história, com ajustes para que fizessem mais sentido com o todo. 
$1^{a}$ Cena

Nas encostas do Corcovado vivem Ana e José.

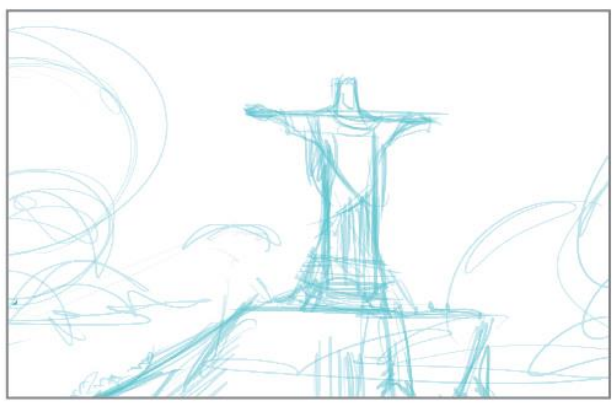

Cristo Redentor de frente

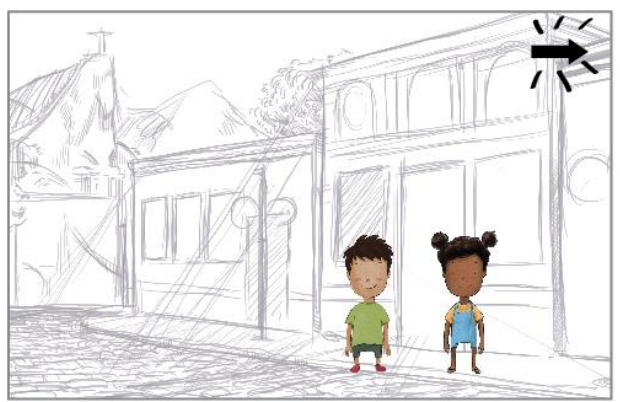

Zoom out Cristo

Aparecem os personagens na vila onde moram e José acena, chamando para começar a história - highlight

\section{$2^{a}$ Cena - continuação}

Ana e José têm muitas coisas em comum, e possuem diferenças também.

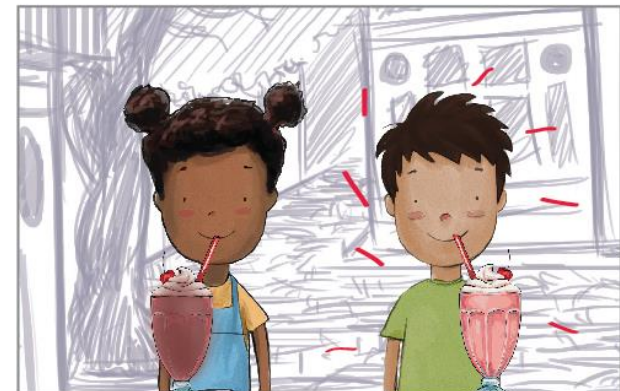

José aparece com dois milkshakes. Highlight para clicar no José para trocarem os milkshakes

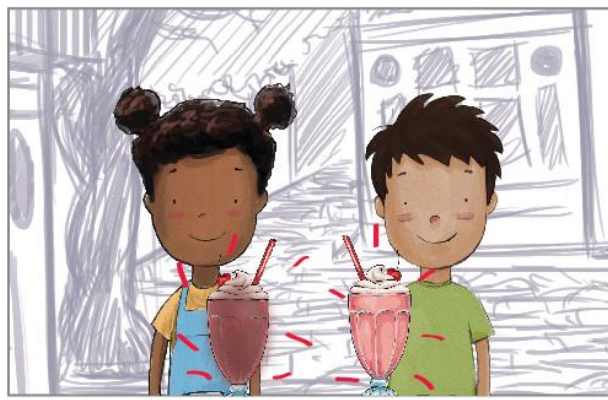

José aparece com dois milkshakes.

Highlight nos milkshakes pata eles beberem

\section{$2^{a}$ Cena}

Ana e José têm muitas coisas em comum, e possuem diferenças também.

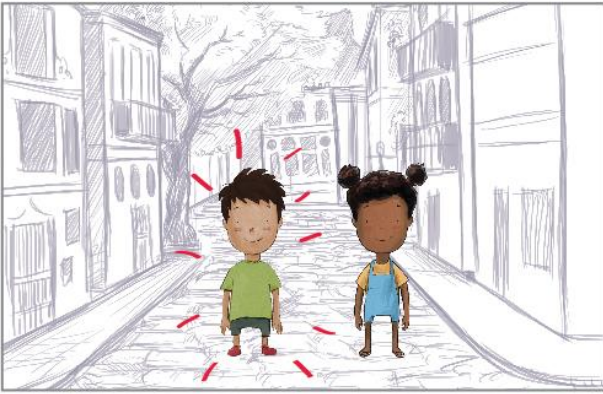

As crianças aparecem na vila. Highlight para clicar no José.

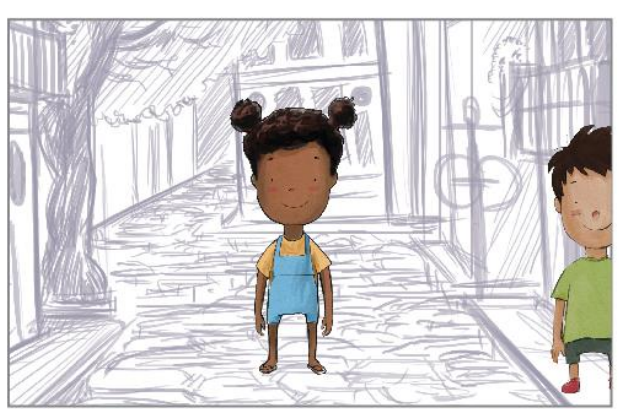

José sai de cena para buscar um milkshake. 
$2^{a}$ Cena - continuação

Ana e José têm muitas coisas em comum, e possuem diferenças também.

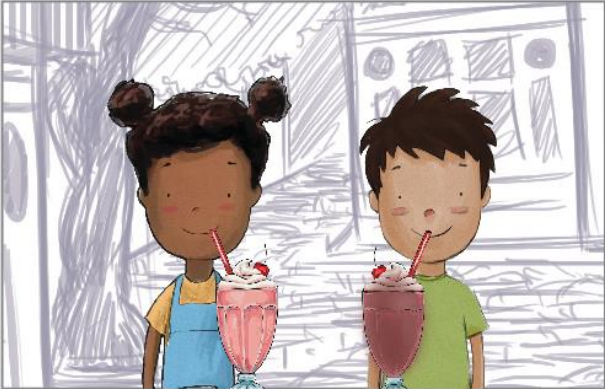

José aparece com dois milkshakes.

Highlight para clicar no José para trocarem os milkshakes

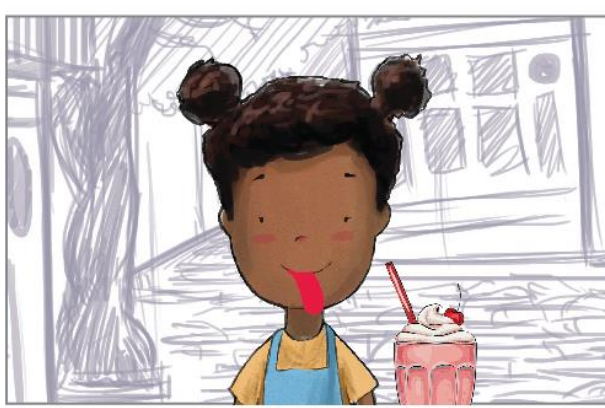

Ana não gosta do sabor do milkshake de José e coloca a língua pra fora.

\section{$2^{a}$ Cena - continuação}

Ana e José têm muitas coisas em comum, e possuem diferenças também.

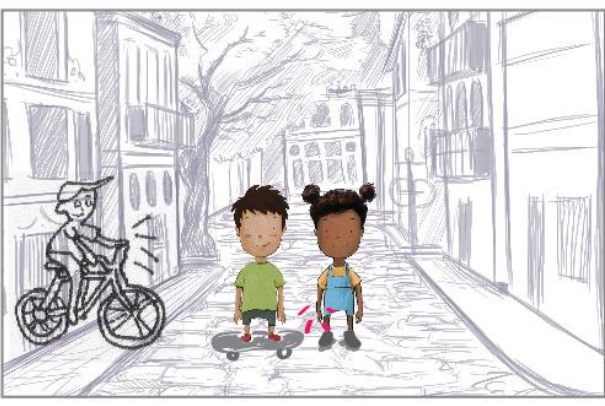

Ana avisa José com um toque no ombro. Highlight na mão de Ana

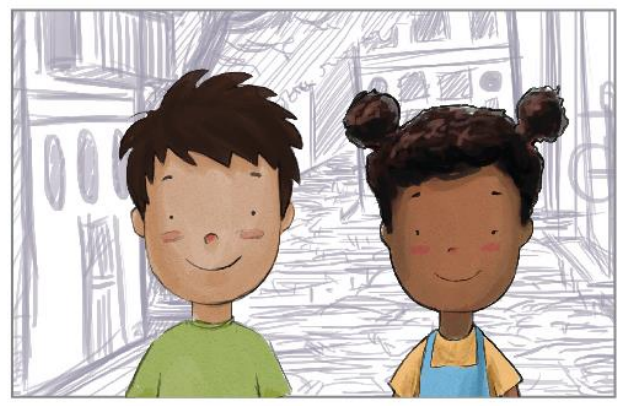

José "falando" muito obrigado em LIBRAS com legenda em Português escrito.

\section{$2^{a}$ Cena - continuação}

Ana e José têm muitas coisas em comum, e possuem diferenças também.

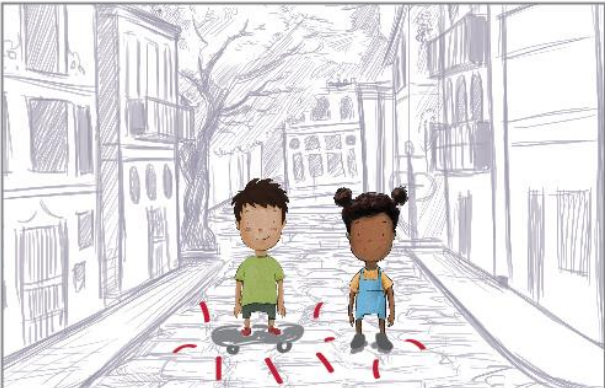

Crianças brincando na vila.

Highlight skate e patins para andarem.

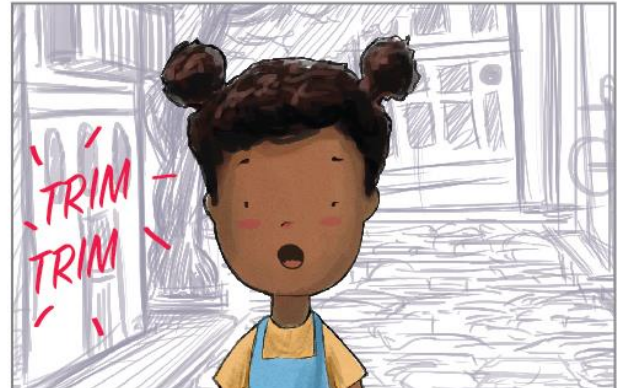

Ana se assusta com o barulho da buzina Barulho de buzina de bicicleta 
$3^{a}$ Cena

A menina e o menino vivem no lugar que vivem seus avós $e$, um dia, viveram seus bisavós.

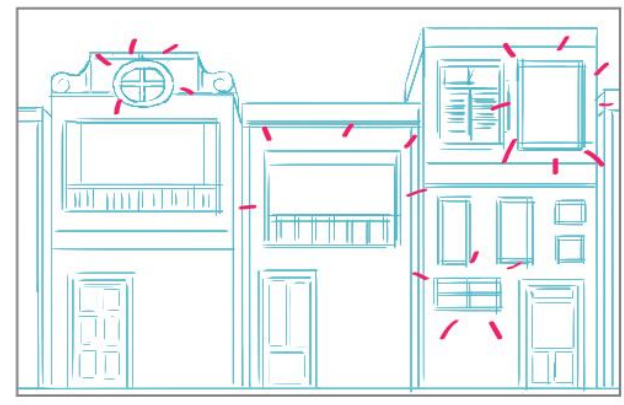

Casas vizinhas na vila.

Highlight nas janelas.

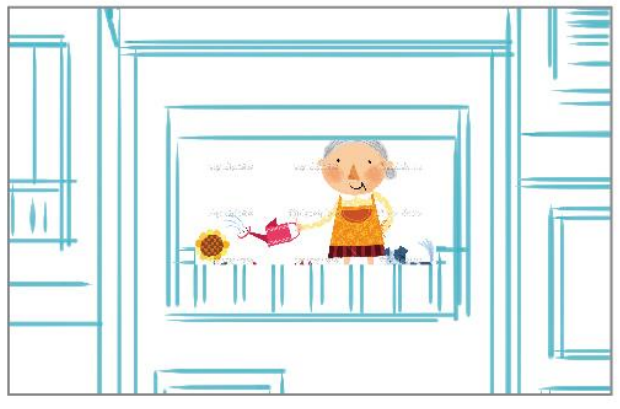

Zoom in na janela clicada

Mulher regando as plantas.

Depois de mostrar a ação, volta para o cenário da vila com as janelas em highlight

\section{$3^{a}$ Cena - continuação}

A menina e o menino vivem no lugar que vivem seus avós $e$, um dia, viveram seus bisavós.

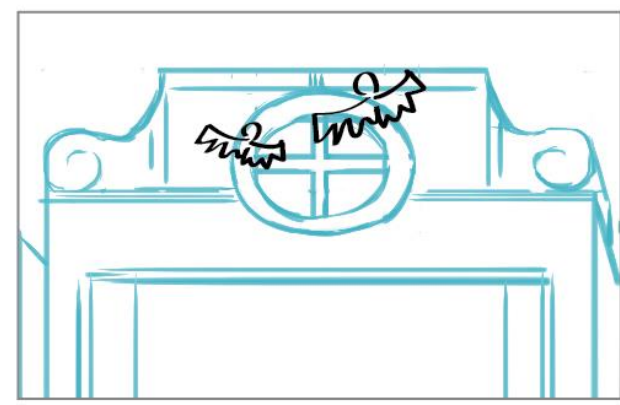

Zoom in na janela clicada

Morceguinhos no sótão da casa.

Depois de mostrar a ação, volta para o cenário da vila com as janelas em highlight

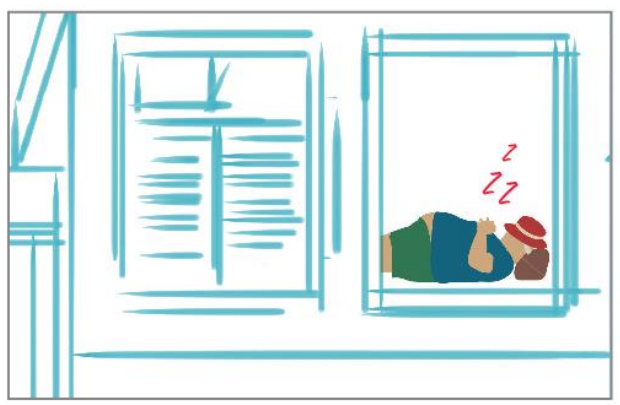

Zoom in na janela clicada

Tiozão dormindo e roncando.

Depois de mostrar a ação, volta para o cenário da vila com as janelas em highlight

\section{$3^{a}$ Cena - continuação}

A menina e o menino vivem no lugar que vivem seus avós e, um dia, viveram seus bisavós.

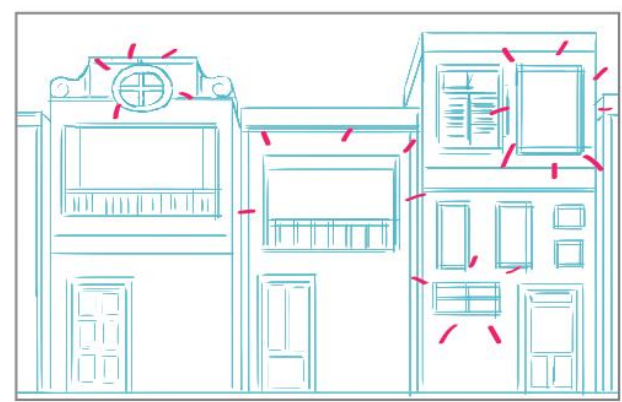

Casas vizinhas na vila.

Highlight nas janelas.

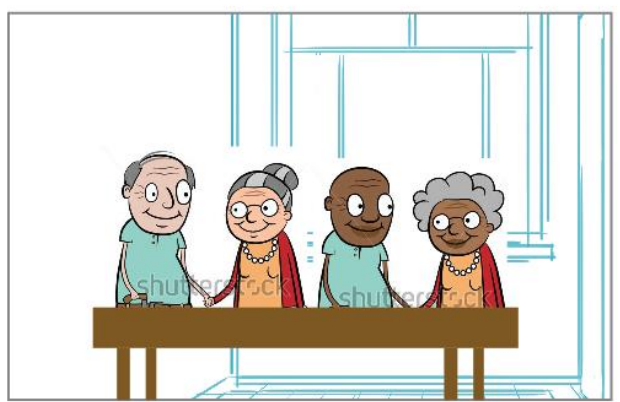

Zoom in na janela clicada

Os avós de Ana e José tomam café juntos. 
$4^{a}$ Cena

Como são amigos desde bem pequenos, Ana e José ali passaram muitos outonos.

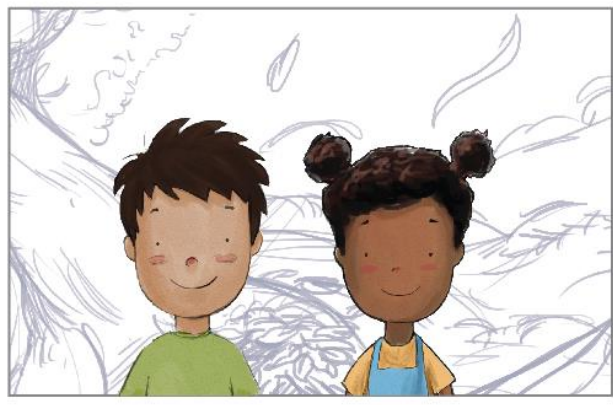

Ana e José na vila com as folhas caindo. Crianças olham para cima.

Inicia o zoom out para a árvore.

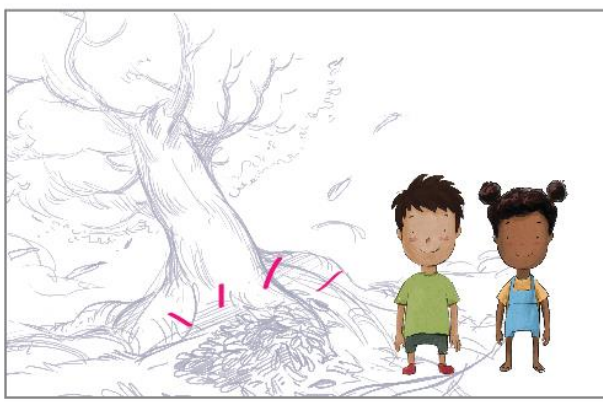

Aparece o montinho de folhas sob a árvore. Crianças brincam com as folhas e aparace o ícone para o usuário assoprar no microfone do iPad.

\section{$4^{a}$ Cena - continuação}

Como são amigos desde bem pequenos,

Ana e José ali passaram muitos outonos.

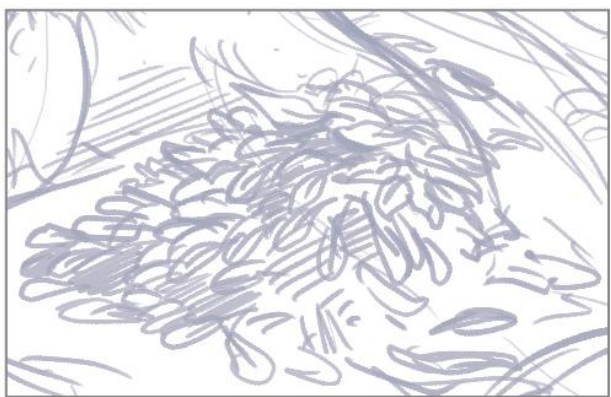

Ao assoprar, as folhas ficam maiores na tela e fazem a transição para a próxima cena.

$5^{a}$ Cena

Vários invernos.

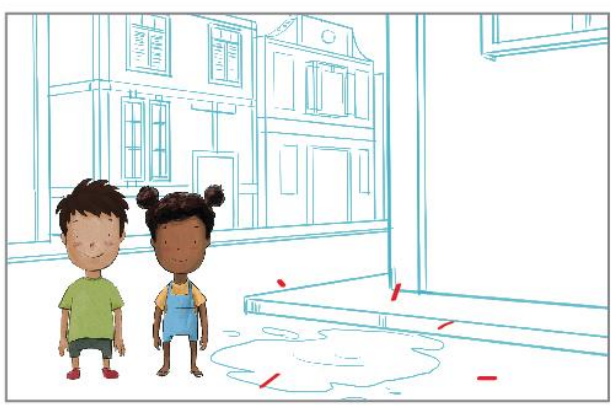

A iluminação escurece para dar o clima de inverno. As crianças estão na vila e começam a formar as primeiras poças de chuva.

Highlight na poça para as crianças pularem.

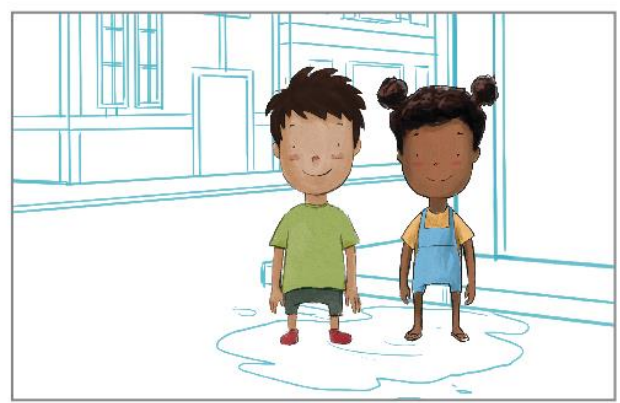


$5^{a}$ Cena - continuação

Vários invernos.

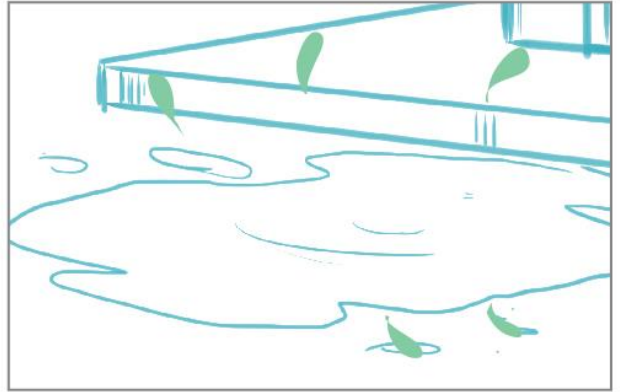

Ao clicar na poça de lama, as gotas inundam a tela.

Passagem para a próxima cena.

$6^{a}$ Cena

Primaveras

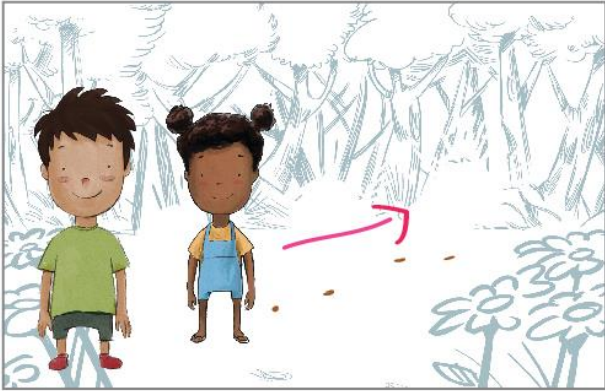

Som dos passarinhos. Ana anda de um lado para o outro da tela, semeando a terra

\section{$6^{a}$ Cena - continuação}

Primaveras

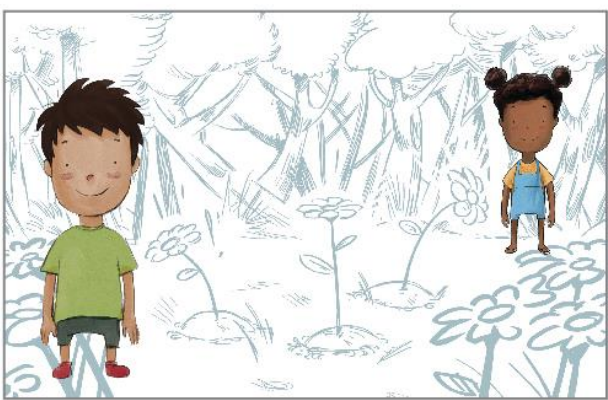

Som dos passarinhos. Ana anda de um lado para o outro da tela, semeando a terra

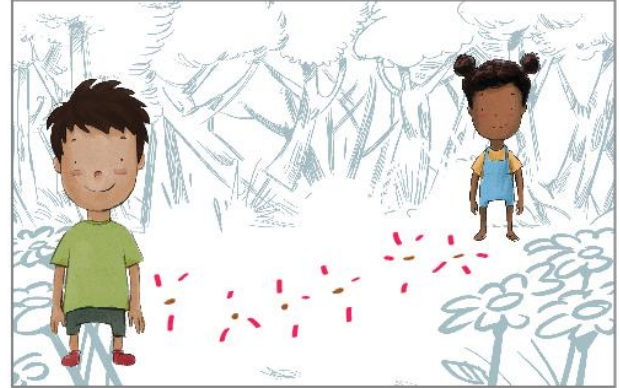

Ana chega do outro lado.

Highlight para clicar onde tem semente

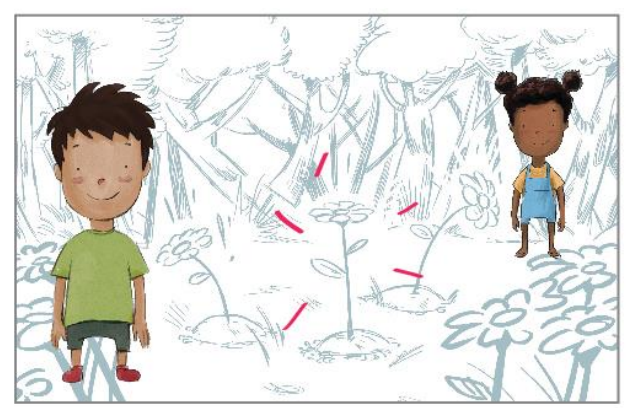

José pega uma flor e dá para Ana Highlight flor 
$7^{a}$ Cena

Everões

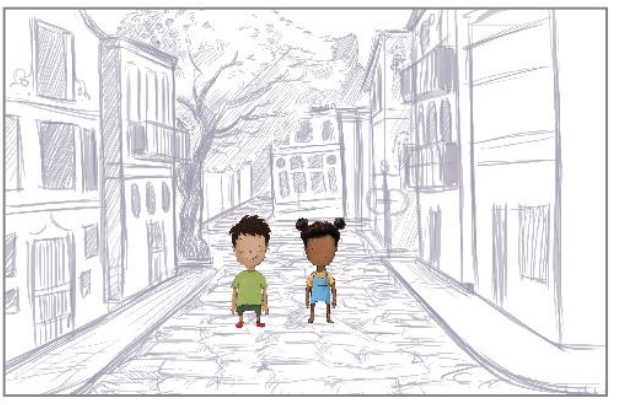

Crianças brincam de pique pega na vila, em um dia ensolarado de verão. Nuvens começam a se formar, anunciando a chuva de verão.

$7^{a}$ Cena

\section{E verões}

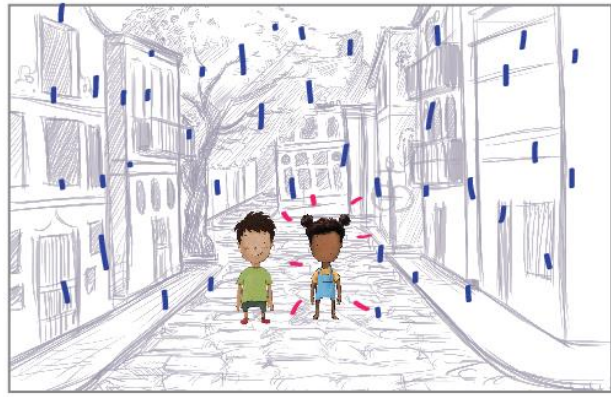

A chuva começa a cair

Highlight em Ana para entrar em sua casa

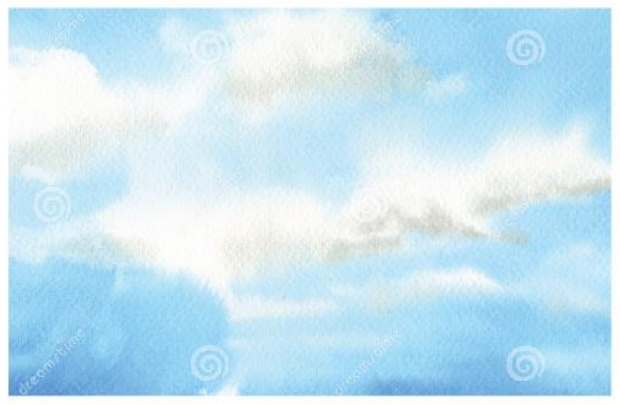

Zoom in nas nuvens

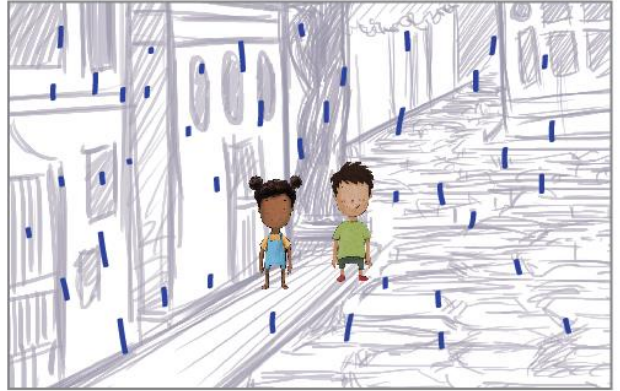

Zoom in nas nuvens

$8^{a}$ Cena

Foi de lá que eles um dia avistaram um largo com casas antigas.

Era o Largo do Boticário.

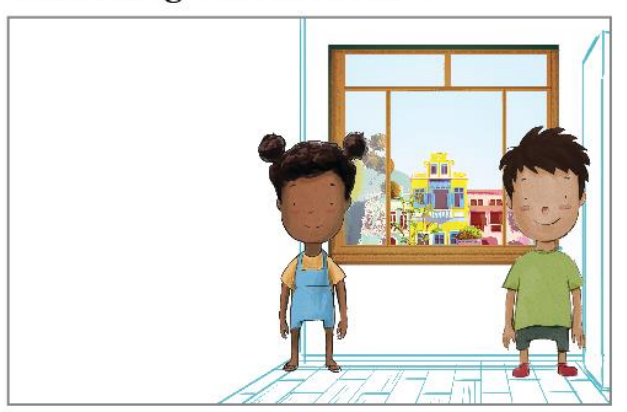

Zoom in para a janela de Ana

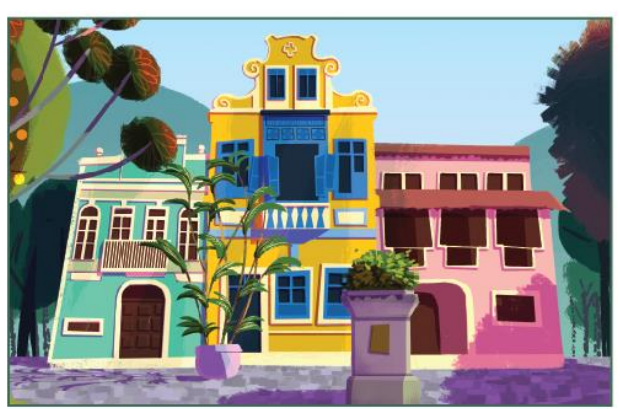

Zoom in no Largo do Boticário 
$8^{a}$ Cena - continuação

Foi de lá que eles um dia avistaram um largo com casas antigas.

Era o Largo do Boticário.

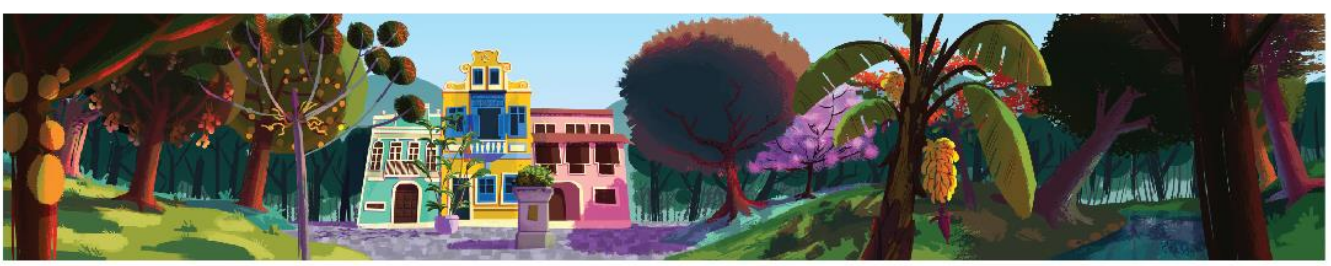

A imagem tem $180^{\circ}$, possibilitando que o

usuário arraste para os dois lados.

Do lao esquerdo, várias espécies de árvores frutíferas.

Do lado direito, o Rio Carioca.

$10^{a}$ Cena

Pelo Largo do Boticário passa o Rio Carioca.

O nome do rio o dado pelo Índios Tamoios.

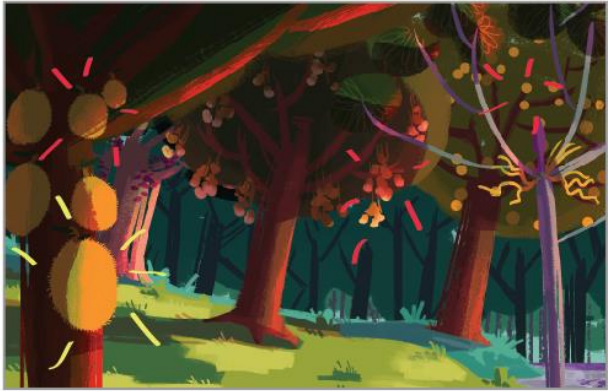

Do lado esquerdo

Clique na árvore e aparece sua espécie e fruto

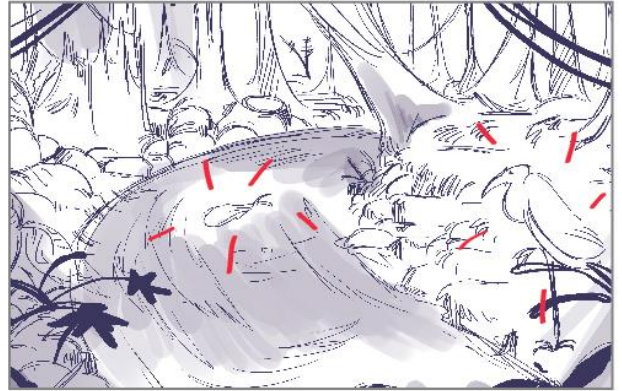

Do lado direito

Clique nos bichinhos e eles farão sons ou ações de acordo com seu comportamento Ao clicar no rio, ele corre mais rápido.

\section{$11^{a}$ Cena}

As pessoas que viviam no Rio de Janeiro naquela época bebiam a água do rio Carioca. E é por isso que chamamos de carioca quem nasce nesta cidade.

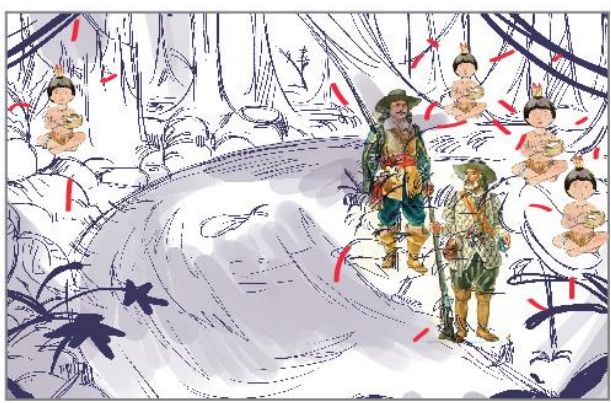

Tratamento sépia para representar a transição de tempo antigo.

Highlight nos índios e brancos para beberem a água do rio. 


\title{
$12^{a}$ Cena
}

A menina e o menino, curiosos para conhecer ainda mais a história de seu bairro, já planejam a próxima aventura: Uma ida ao Largo do Boticário.

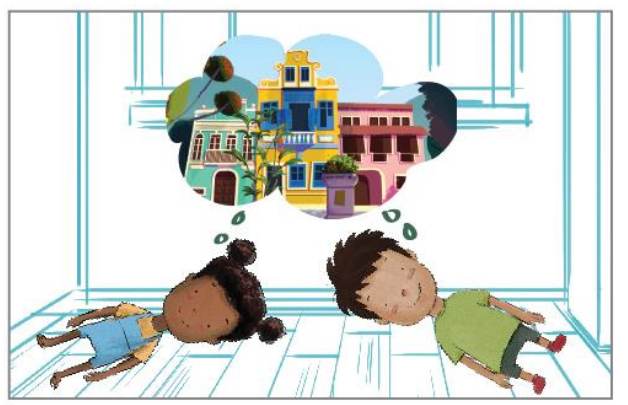

Fade out do Largo do Boticário para o pensamento de Ana e José

Ana e José deitados no chão do quarto, pensando em sua próxima aventura!

Figura 19: Storyboard da história

\subsection{7 \\ Tipografia}

Antes das fontes open source - código aberto -, desenvolvedores tinham que usar em seus projetos fontes de sistema ou comprar famílias tipográficas licenciadas para a web e inseri-las no código de seus projetos. A cada família ou variação adicionada, acrescentava-se um pouco mais de tempo ao carregar uma página.

Mesmo tendo a possibilidade de acrescentar uma família tipográfica ao aplicativo da nossa história, optamos por utilizar uma fonte open source. Além da sua natureza ser o uso display, o que por si só já promove a boa leitura e legibilidade em telas, temos menos risco ao promover adaptações para sistemas operacionais diferentes.

\begin{abstract}
A API, ou "application programming interface", é basicamente um servidor da web que oferece dados sob demanda e pode cobrir tudo e qualquer coisa, desde mapas até serviços bancários móveis. A API de fontes do Google fornece uma biblioteca pública gratuita de tipos de fontes para aplicativos da web e móveis. Desde o lançamento no Google I / O em 2010, ele vem se desenvolvendo constantemente e atualmente veicula bilhões de páginas para bilhões de usuários todos os meses em milhões de sites em todo o mundo.
\end{abstract}

(GOOGLE FONTS, 2018, tradução livre)

A partir desta escolha, optamos por usar a Roboto no aplicativo. Por apresentar formas geométricas em seu desenho, ele transmite esse caráter mais lúdico que seguimos como parâmetro em nossa busca. Dessa forma, apresenta curvas 
amigáveis que ajudam a criar um ritmo confortável para a leitura, assim como desenhos de famílias mais humanistas, como descreve o tipógrafo principal dessa família, Christian Robertson (Google Fonts).

Além disso, é uma família que está em constante desenvolvimento e aprimoramento, e é usada em mais de 22,000,000 de websites pelo mundo, tendo aderência expressiva no Brasil.

\subsection{8}

\section{Wireframes}

Para guiar o desenvolvimento e o posicionamento dos botões e do intérprete, testamos algumas formas de distribuição dos ícones na interface. Sempre ao começarmos uma nova cena, o intérprete entrará junto com o cenário e personagens para contextualizar a história.

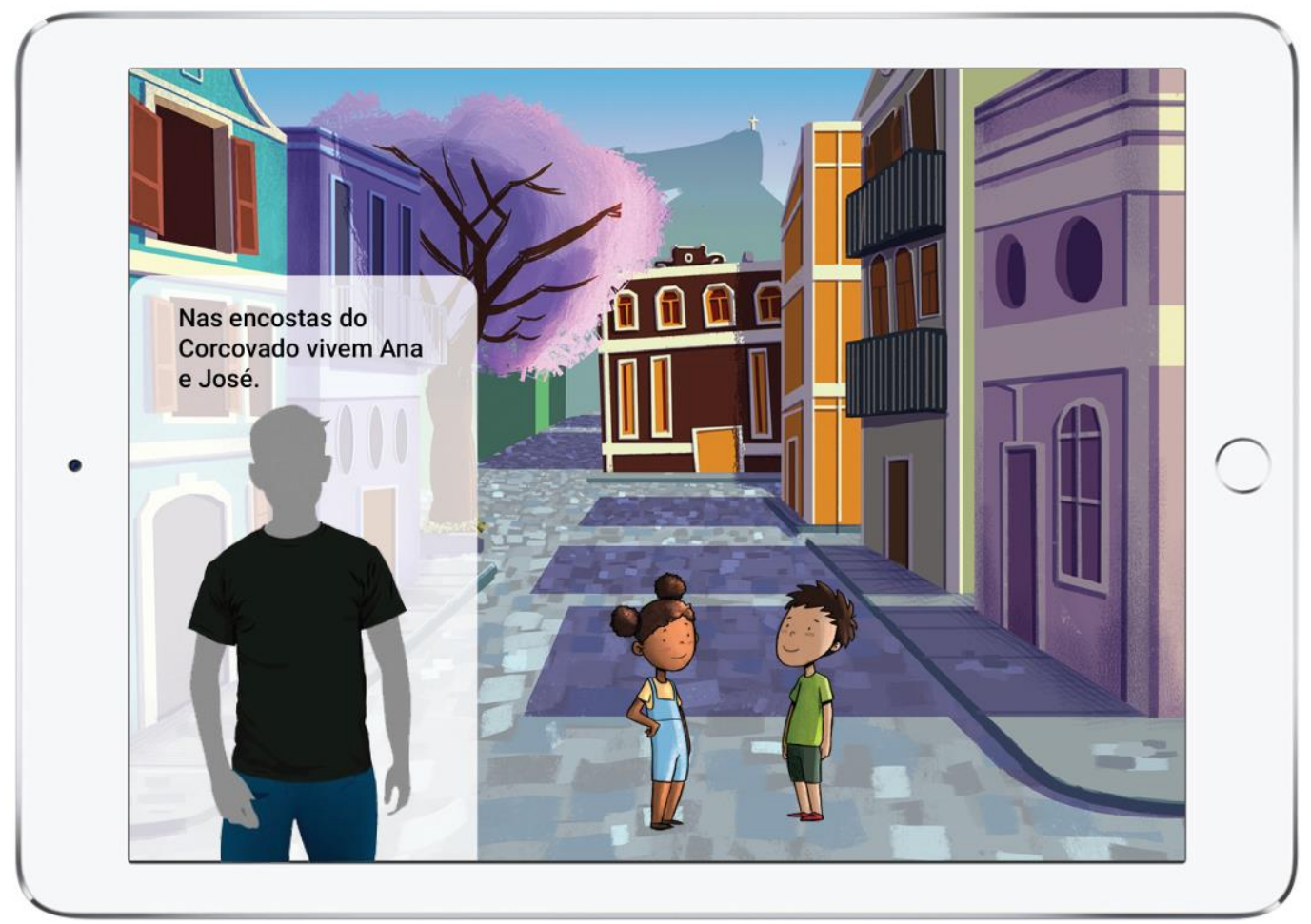

Figura 20: Abertura de cena (cenário, personagens e intérprete). Fonte: arquivo LIDE.

Quando a parte textual e de LIBRAS terminar, o intérprete sumirá, aparecendo o ícone para a criança clicar indicando que existe alguma atividade ou, então, para avançar para a próxima cena. 


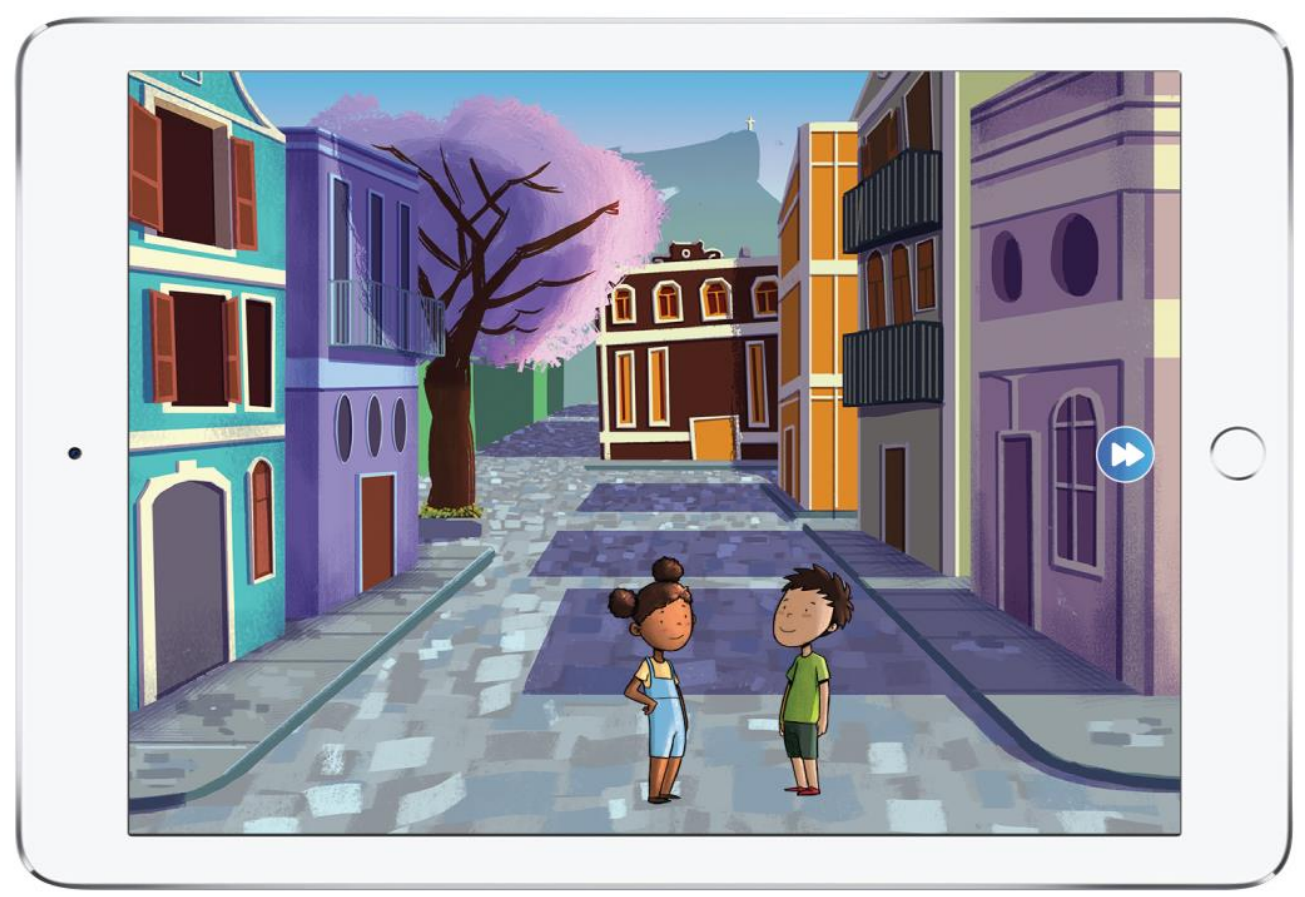

Figura 21: Personagens, cenário e ícone de avançar. Fonte: arquivo LIDE.

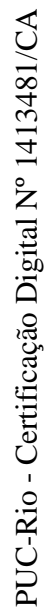

Se a criança quiser pausar a história ou precisar algum recurso de configuração, por exemplo, ela dará um clique na tela para que os ícones apareçam. Nesse momento, todos os ícones disponíveis para ações aparecem na tela: página inicial, avanço, retrocesso, configurações, pausa/play.

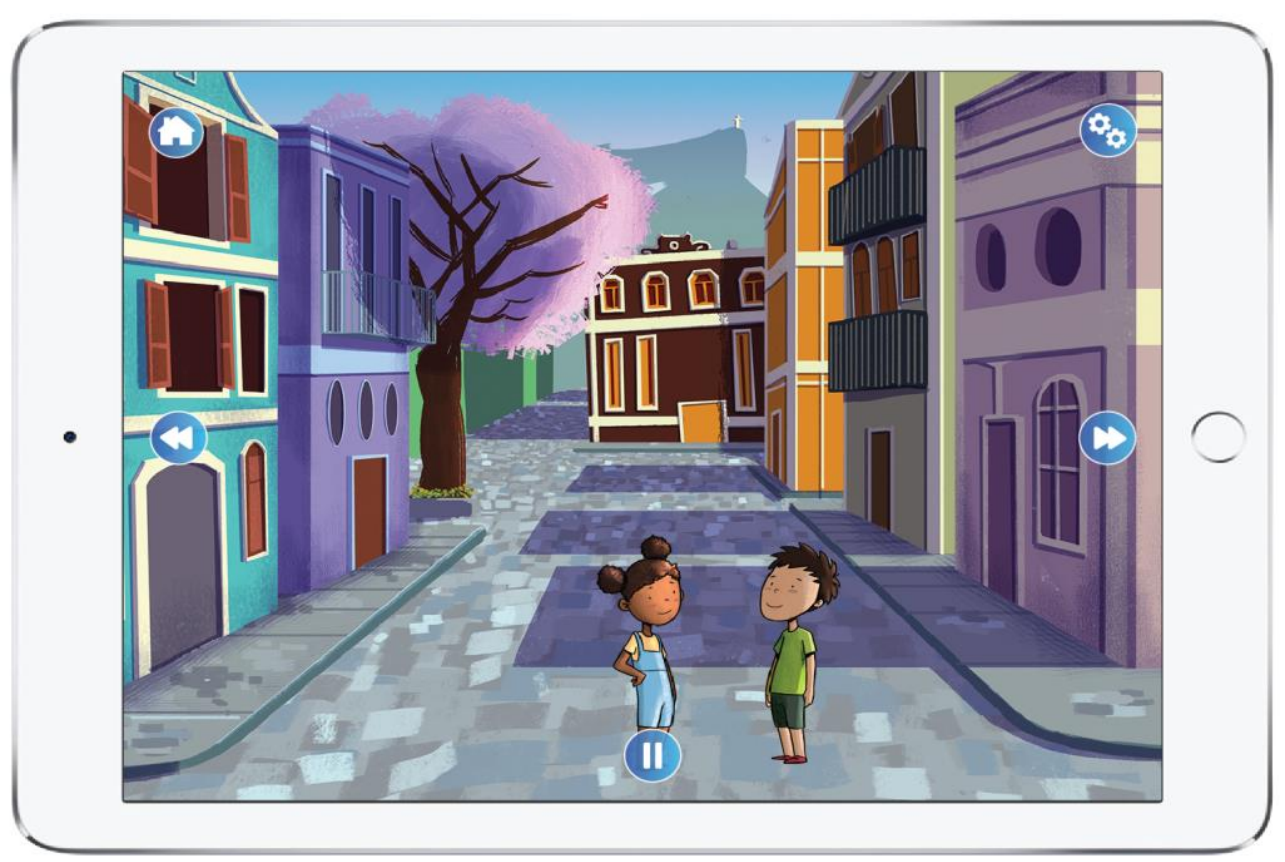

Figura 22: Personagens, cenário e ícones. Fonte: arquivo LIDE. 


\section{3 \\ Síntese dos temas abordados}

Neste capítulo, descrevemos as etapas percorridas para a criação de um livro digital inclusivo para crianças surdas e ouvintes. O objetivo principal é deixar claro que qualquer projeto pode ser também inclusivo. Bastam alguns ajustes no escopo e interface do projeto.

Este projeto começou em 2014, ano em que muitos investimentos foram feitos na cidade do Rio de Janeiro, em função de eventos como as Olimpíadas. Portanto, a escolha pela região do Largo do Boticário deu-se em um momento em que o Rio de Janeiro estava diante dos olhos do mundo. Além, é lógico, de ser a cidade natal e/ou de residência de membros do LIDE.

A criação da história e dos personagens, assim como a escolha do caminho gráfico e das interações deu-se devido a experiência dos membros do LIDE em projetos voltados para crianças surdas. Por muitas vezes, desenvolvemos projetos em parceria com o INES e acompanhamos a rotina dos alunos na instituição e, também, relatos de professores e profissionais em geral que convivem com estas crianças.

A escolha de trabalhar com aproximadamente $1 / 3$ de tela para o intérprete de LIBRAS veio de pesquisa de similares, da reflexão pautada em nossa experiência sobre a convivência com o público e da metodologia do Design, em projetar pensando sempre no público alvo. À época da pesquisa de similares, só encontramos um aplicativo infantil que usasse a LIBRAS. Mesmo assim, o uso seguia um padrão de uma faixa pequena, reservada ao canto esquerdo da tela, com um intérprete adulto falando em LIBRAS. Dessa forma, não estaríamos projetando para o nosso público e, sim, apenas replicando um padrão. A ideia de usarmos um intérprete jovem, especialmente um adolescente surdo, veio do entendimento de que crianças projetam suas referências em amigos ou ídolos que tem a sua idade ou são um pouco mais velhos. Essa reflexão não foi feita sob pesquisa teórica, mas da vivência da equipe do LIDE e do relato de professores do INES. Usar uma criança entre 7 e 8 anos, poderia comprometer a aprendizagem de LIBRAS por este público e por crianças ouvintes. Crianças com esta idade ainda não refinaram a linguagem gestual. Usar um adolescente, além de representar um modelo aspiracional e 
inspiracional, também é uma forma de usar a LIBRAS de forma mais alinhada com a versão formal, digamos assim.

Como aponta o nosso quadro metodológico, a programação foi a única parte não desenvolvida. Questões sobre a interface serão avaliadas em conjunto com o programador. Esta etapa está começando agora e estima-se que seja finalizada até meados de 2019. 


\section{5 \\ Conclusão}

Retomar a discussão sobre o potencial do Design no âmbito no EnsinoAprendizagem com foco em crianças surdas, mais uma vez se revelou uma fonte inesgotável de reflexão e inspiração. Mesmo após 13 anos de pesquisa sobre esse tema, ainda me sinto motivada como na primeira reunião que participei no LIDE. Como não há meio de separar pessoal e profissional, meu papel vai além da pesquisa e me empenho em disseminar, sempre que questionada, sobre a relevância de projetos desenvolvidos com foco em grupos que não estão no centro das grandes produções da indústria.

Se me sensibilizei quando ainda era uma jovem adolescente entrando na faculdade e descobrindo todo o potencial do Design, hoje, como pesquisadora e mãe vou além do meu campo profissional e olho para o mundo com mais empatia, tentando me colocar na situação do outro, observando, escutando e refletindo sobre a minha contribuição para que essas crianças tenham oportunidades ao seu alcance como minha filha, ouvinte, tem.

Ao estudar sobre as questões enfrentadas na alfabetização bilíngue de crianças surdas no Brasil, entendemos como a linguagem é fundamental para a formação social da mente e para o desenvolvimento do indivíduo como cidadão na sociedade. Quando expostas à linguagem na mais tenra idade, crianças surdas e ouvintes são capazes de se desenvolver de forma igual.

Os pais devem estar preparados para descobrir com o seu filho o mundo que o cerca e que faz sentido para as suas necessidades/habilidades. Pais ouvintes tendem a explorar a oralidade tão confortavelmente, pois a audição lhes é natural. Quando a criança é surda, deve haver um esforço dos pais na constante busca pela compreensão das necessidades de seu filho e de meios que incentivem o seu 
crescimento. Neste caso, pais ouvintes devem aprender a língua de sinais e pesquisar sobre atividades naturais para ele, explorando recursos visuais, táteis e interativos, deixando posturas paternalistas de lado.

As relações estão sendo transformadas pela convergência e pela ubiquidade da comunicação. Acredito que a tecnologia pode colaborar no que diz respeito à disseminação de conteúdos desenvolvidos especialmente para este público. Sob esta perspectiva e à luz da experiência da equipe do LIDE em observações no INES, identificamos que crianças surdas tendem a focar mais em uma atividade quando interagem com a mesma. Além disso, o hábito de contar histórias ajuda as crianças a fazerem a correlação no bilinguismo e a se situarem sócio e espacialmente.

Consideramos que o hábito de conhecer, ouvir ou ler histórias, desde os primeiros anos de vida, pode nos tornar pessoas mais reflexivas e construir o senso crítico. A narrativa interativa digital bilíngue é um meio que pode ser desenvolvido para o convívio mútuo de crianças surdas e ouvintes, gerando conhecimentos sobre aspectos importantes da vida em sociedade.

Neste sentido, como afirma Galvão (2005), as narrativas, produzidas na forma oral, escrita ou hipermidiática, têm grande potencial educacional. Elas podem ser utilizadas tanto para investigar o conhecimento que as pessoas expressam quanto para auxiliar processos de construção de conhecimento.

A forma de narrativa digital que está surgindo abrange muitos formatos e estilos diferentes, mas é, essencialmente, uma entidade única e inconfundível. Não é um "isto" ou "aquilo" interativo - embora muito dessa forma possa ser extraído da tradição - mas uma reinvenção do próprio ato de contar histórias para o meio digital. (MURRAY, 2003, p. 236) ${ }^{27}$. E que a leitura interativa possa permitir uma interação ativa e imersão em seu conteúdo a todos que desse momento participarem.

\footnotetext{
${ }^{27}$ MURRAY, J. Hamlet no Holodeck: o futuro da narrativa no Ciberespaço. SP: Itaú
} Cultural UNESP, 2003. 
Ao percorrer as etapas para a criação e o desenvolvimento da narrativa digital interativa bilíngue, constatamos como há carência de materiais inclusivos, da mesma forma que há um grande espaço para que projetos (acadêmicos ou da indústria do entretenimento) promovam essa inclusão.

É gratificante ter chegado até a etapa de pré programação dessa narrativa. Foi muito importante pontuarmos todos os itens, as etapas e a equipe necessária para a sua criação e desenvolvimento. Algumas escolhas durante o percurso foram fundamentais para caracterizar a nossa narrativa:

a) Amizade: o objetivo de tecer a história sobre da amizade dos personagens principais foi tratar a surdez apenas como uma diferença entre duas pessoas que se respeitam e se gostam e não como ponto principal de partida de sua construção;

b) Características dos personagens: a ideia era "distribuir as cargas" histórias e de preconceitos, abrangendo a diversidade do nosso país. Sendo assim, Ana é uma menina negra ouvinte. José é um menino branco surdo;

c) Intérprete e sua ocupação na interface: usar um jovem rapaz, surdo e ator colabora para aproximar as crianças da narrativa, assim como seu posicionamento em quase 1/3 da tela. Esta decisão coloca o intérprete como elemento de destaque na hierarquia da informação na narrativa. Esse direcionamento não foi encontrado em nenhum material durante a pesquisa de interações e de similares;

d) Múltiplos temas da história: descrevemos os amigos Ana e José, suas famílias, o local onde vivem, características da vizinhança, a passagem do tempo, a cidade do Rio de Janeiro em um contexto histórico e a flora local. Esses temas são importantes para ajudar a criança surda a contextualizar questões que são mais complexas de serem ensinadas, no que diz repeito à comunicação familiar (pais ouvintes e filho surdo);

e) Tipografia open source: como a tecnologia avança rapidamente, optamos por seguir com uma família aberta, variada e testada em muitos projetos pelo 
mundo para que facilitasse uma futura adaptação de suporte, caso seja necessário;

f) Complementaridade entre texto e imagem: essencial para que tantos elementos coubessem na mesma tela (cenário, personagens, intérprete, texto em português);

g) Interações: como vimos, crianças surdas se sentem mais estimuladas e tendem a prestar mais atenção à atividade proposta quando interagem com a mesma.

A parte de programação não foi concluída até o final desta defesa, mas estima-se que o primeiro protótipo fique pronto em meados de 2019. Como o programador ainda não foi envolvido no processo de criação, provavelmente alguns ajustes poderão ser realizados na interface.

Mesmo que a escrita da tese seja linear, a criação e o desenvolvimento da narrativa digital interativa bilíngue não foi. Muitas etapas aconteceram em paralelo. Enquanto o capítulo de descrição não estava concluído, a equipe deste projeto de pesquisa publicou muitos artigos e em anais de congressos, periódicos, capítulos em livros e participou de congressos nacionais e internacionais. Além disso, ganhamos um Edital Universal, um apoio ao material didático da FAPERJ, dois jovens cientistas e esta tese.

Minha colaboração específica foi pesquisar e escrever todo o referencial teórico, participar das decisões de projeto e fazer a documentação exaustiva de todo o processo.

De minha parte, sou muito grata por ter a oportunidade de dedicar tantos anos da minha vida ao estudo e fomento deste tema. Minha intenção é conseguir disseminar, de forma relevante, que podemos/devemos fomentar projetos com este cunho, tanto na área acadêmica, como por grandes empresas desenvolvedoras de jogos e aplicativos. 


\section{Referências bibliográficas}

BAKHTIN, Mikhail (V.N. Volochínov). "Língua, Fala e Enunciação" In Marxismo e Filosofia da Linguagem: problemas fundamentais do método sociológico na ciência da linguagem. "A Interação Verbal" In — - Tradução Michel Lahud e Yara Frateschi Vieira; colaboração Lúcia Teixeira Wisnik e Carlos Henrique D. Chagas Cruz. 4 ${ }^{\mathrm{a}}$ Ed. - São Paulo: Editora Hucitec, 1988.

BARBOSA FILHO, André, CASTRO, Cosette, TAKASH, Tome (organizadores). Mídias Digitais - Convergência Tecnológica e inclusão social. Editora Paulinas: 2005.

BRAGA, Regina Maria; SILVESTRE, Maria de Fátima. Construindo o leitor competente: atividades de leitura interativa para a sala de aula. São Paulo, Global:2009.

BERNABÓ. Maria Aparecida. LIBRAS e português em jogo: Design e arte em parceria. Dissertação (Mestrado em Design). Departamento de Artes \& Design. Pontifícia Universidade Católica do Rio de Janeiro, Rio de Janeiro, 2008.

BONSIEPE, Guilherme. Design, Cultura e Sociedade. São Paulo: Blucher, 2011.

BRUNER, Jerome. Juego, Pensamiento y Lenguaje, en "Perspectivas" Vol. XVI, nI, 1986.

BUCHT, C. \& FIELITZEN, C. Perspectivas para a criança e a mídia. Brasília. MEC- UNESCO, 2001.CAVALCANTI, Marilda C. Estudos sobre educação bilíngüe e escolarização em contextos de minorias lingüísticas no Brasil. Delta: 1999

CANÁRIO, Rui. A escolar tem futuro? Das promessas às incertezas. Porto Alegre : Artmed, 2006. 160 p. : il. P\&b ; $23 \mathrm{~cm}$

CARVALHO, G. S. As Histórias Digitais: Narrativas no Século XXI. 0 Software Movie Maker como Recurso Procedimental para a Construção de Narrações. Dissertação (Mestrado em Educação), Universidade de São Paulo. São Paulo, 2008. Disponível em:http://www.teses.usp.br/teses/disponiveis/48/48134/tde-27082010104511/publico/Gracinda_Souza_de_Carvalho.pdf. Acessi 22 jan. 2016.

CORREIA, Ana; COUTO, Rita; PORTUGAL, Cristina. Multi-Trilhas Virtual: novas diretrizes para o jogo de entretenimento na aquisição da linguagem por crianças surdas. Rio de Janeiro, 2012. 129p. 
Dissertação de Mestrado - Departamento de Artes e Design, Pontifícia Universidade Católica do Rio de Janeiro.

CORREIA, A. T. P.; Couto. R. ; PORTUGAL. C. . Multi-Virtual: novas bases para o jogo de entretenimento na aquisição da linguagem por crianças surdas. In: CIPED Congresso Internacional de Pesquisa em Design, 2011, Lisboa. IV Congresso Internacional de Pesquisa em Design, 2011.

CORREIA, A. T. P.; Couto. R. . Aquisição de Linguagem por Crianças Surdas através de Histórias Interativas: Objeto Didático Virtual. In: XIV Seminário de Iniciação Científica da PUC-Rio, 2006, Rio de Janeiro. XIV Seminário de Iniciação Científica da PUC-Rio, 2006. p. 453-454.

CORREIA, A. T. P.; Couto. R. ; PORTUGAL. C. . MULTI-TRILHAS VIRTUAL Novas diretrizes para o jogo de entretenimento na aquisição da linguagem por crianças surdas. 2011.

CORREIA, A. T. P.; Couto. R. . Aquisição de Linguagem por Crianças Surdas através de Histórias Interativas: Objeto Didático Virtual. 2006

CORREIA, A. T. P.; WILMER. C. . Fábulas para crianças surdas. 2007. (Desenvolvimento de material didático ou instrucional - Projeto Conclusão do curso de Bacharel em Design PUC-Rio).

COSTA, Ivanilson. Novas Tecnologias: desafios e perspectivas na educação. 2011.

COOPER, Allan. Inmates Are Running the Asylum, The: Why High-Tech Products Drive Us Crazy and How to Restore the Sanity. Sams Publishing. p. 288.

COUTO, Rita Maria de Souza. Movimento interdisciplinar de designers brasileiros em busca de educação avançada. PONTIFÍCIA UNIVERSIDADE CATÓLICA DO RIO DE JANEIRO Departamento de Educação. PONTIFÍCIA UNIVERSIDADE CATÓLICA DO RIO DE JANEIRO. 1997. 246f. Tese (Doutorado) - Pontifícia Universidade Católica do Rio de Janeiro, Departamento de Educação.

COUTO, Rita Maria de Souza Couto; WILMER, Celso ; PORTUGAL, Cristina ; CORREIA, Ana. Do concreto ao virtual: Interatividade no letramento de indivíduos surdos. In: $2^{\circ}$ Congresso Brasileiro de Design da Informação e 1ㅇ InfoDesign Brasil - Congresso Brasileiro de Design da Informação, 2005, São Paulo. Anais do $2^{\circ}$ Congresso Internacional de Design da Informação e 10 InfoDesign Brasil - Congresso Brasileiro de Design da Informação. São Paulo : Centro Universitário Senac, 2005. v. 1.

COUTO, Rita Maria de Souza Couto; PORTUGAL, Cristina; JORDY, Eliane; CORREIA, Ana Tereza. Design para projeto de livro digital interativo para crianças surdas. In: MX Design Conference 2015, 2015, Cidade do México. MX Desugn Conference 2015 Diseño Incluyente. Cidade do México, 2015. v. 1.

COUTO, Rita Maria de Souza Couto; PORTUGAL, Cristina; JORDY; Eliane; CORREIA, Ana Tereza. Design e literatura digital interativa 
bilíngue. In: 7th Information Design International Conference, 2015, Brasília. Proceedings of the 7th Information Design International Conference. São Paulo: Editora Edgard Blücher, 2015. p. 603.

COUTO, Rita Maria de Souza Couto; PORTUGAL, Cristina; JORDY, Eliane; CORREIA, Ana Tereza ALRAM, Felipe; BRUNNET, Nathália; RIBEIRO,

Lucas.

Design and interactive bilingual literature In: Selected Readings of the 7th Information Design International Conference.1 ed.Brasília : Sociedade Brasileira de Design da Informação, 2016, v.1, p. 51-63.

COUTO, Rita Maria de Souza Couto; PORTUGAL, Cristina; JORDY, Eliane; CORREIA, Ana Tereza; CORREA, Mariana Ferreira Gomes. Interactive digital book for deaf and listener children In: Interactive digital book for deaf and listener children, 2014, Barcelona.EDULEARN14, the 6th annual International Conference on Education and New Learning Technologies. Barcelona: IATED, 2014.

COUTO, Rita Maria de Souza; PORTUGAL, Cristina; CORREIA, Ana Tereza Pinto de Sequeiros; IUNG, Eliane Jordy; CORREA, Mariana Ferreira Gomes. Projeto de pesquisa de livro digital para crianças surdas e ouvintes a luz do design em situações de ensinoaprendizagem. selectln: $11^{\circ}$ Congresso Brasileiro de Pesquisa e Desenvolvimento em Design, Gramado. Anais do $11^{\circ}$ Congresso Brasileiro de Pesquisa e Desenvolvimento em Design. , 2014. v.1. p.1492 - 1503

COUTO. R. ; WILMER. C. ; PORTUGAL. C. ; CORREIA, A. T. P. . Do concreto ao virtual: Interatividade no letramento de indivíduos surdos. In: Anais do $2^{\circ}$ Congresso Internacional de Design da Informação e $1^{\circ}$ InfoDesign Brasil, 2005, São Paulo. Congresso Brasileiro de Design da Informação., 2005.

CROSS, Nigel. Post-Industrial Design Education. Keynote Speech, Education Forum, Internacional Council of Societies of Industrial Design (ICSID), Seoul, Korea, 10 October 2001.

EISNER, Will. Quadrinhos e arte sequencial: princípios e práticas do lendário cartunista / Will Eisner; tradução Luís Carlos Borges, alexander Boide. - 4르 ed. - São Paulo: Editora WMF Martins Fontes, 2010.

EISNER, Will. Narrativas gráficas de Will Eisner / escrito e ilustrado pelo autor; tradução : Leandro Luigi Del Manto. $-2^{\underline{a}}$ ed. - São Paulo : Devir, 2008.

DEMENCIANO COSTA, Leandro; COUTO, Rita Maria de Souza. O que os jogos de entretenimento tem que os jogos com fins pedagógicos não tem: princípios para projetos de jogos com fins pedagógicos. Dissertação de Mestrado em Artes \& Design - Pontifícia Universidade Católica do Rio de Janeiro; Rio de Janeiro, 2008. 120 folhas.

FINDELI, Alain. Rethinking Design Education for the 21st Century: theoretical, methodological, and ethical discussion. In.: Design Issues: Volume 17, Number 1. MIT, 2001. 
FREIRE, Wendel (Org.). Tecnologia e educação: as mídias na prática docente. Rio de Janiero: Wak Ed., 2008.

GALVÃO FILHO, Teófilo Alves. Tecnologia Assistiva: favorecendo o desenvolvimento e a aprendizagem em contextos educacionais inclusivos. In: GIROTO, C. R. M.; POKER, R. B.; OMOTE, S. (Org.). As tecnologias nas práticas pedagógicas inclusivas. Marília/SP: Cultura Acadêmica, p. 65-92, 2012.

GIANNETTI, Claudia. Estética Digital. Sintopia da Arte, a Ciência e a Tecnologia. Belo Horizonte: C/Arte, 2006.

GATES, Bill. Content is King, disponível em https://medium.com/@HeathEvans/content-is-king-essay-by-bill-gates1996-df74552f80d9. Acesso em: 2 fev. 2017.

GOOGLE FONTS, Hot Type, Always Fresh, disponível em https://design.google/library/hot-type-always-fresh/. Acesso em: 4 ago. 2018.

GOOGLE. Google Mobile Day, disponível em https://www.youtube.com/watch?v=19n9u5fo-zc. Acesso em: 10 ago. 2015. GOSCILA, Vicente. Roteiro para as novas mídias. Do cinema às mídias interativas. São Paulo: Editora Senac, 2008.

JENKINS, Henry. Cultura da convergência: a colisão entre os velhos e novos meios de comunicação / Henry Jenkins; tradução Susana Alexandria. - 2ª ed. - São Paulo: Aleph, 2009.

KRISTEVA, Julia. História da Linguagem. Tradução Maria Margarida Barahona. Edições 70 - Lisboa, Portugal: Colecção Signos, 1969.

LEMOS, André. Anjos interativos e retribalização do mundo. Sobre interatividade e interfaces digitais. [online] Disponível na Internet via URL: $\quad$ <http://www.facom.ufba.br/ciberpesquisa/lemos/interativo.pdf > Acessado em: abril de 2010.

LUCHESI, Maria Regina C., Educação de Pessoas Surdas: Experiências, Histórias Vividas. Campinas, SP: Papirus, 2003 - (Séria Educação Especial)

MANOVICH, Lev. The language of New Media. Massachusetts: The MIT Press, 2001.

MARCONDES. Beatriz; TOSHMITSU, Thaís; MENEZES, Gilda. Como usar outras linguagens na sala de aula. São Paulo: Contexto, 2008.

MARINHO, Marildes (Org.). Ler e navegar: espaços e percursos da leitura. Campinas, SP: Mercado de Letras: Associação de Leitura do Brasil - ALB, 2001. (Coleção Letras no Brasil).

MEADOWS, Mark Stephen. Pause \& Effect: The Art of Interactive Narrative. Indiana: New Riders, 2003.

MILLER, Carolyn Handler. Digital Storytelling: A creator's guide to interactive entertainment. Taylor \& Francis: 2008. 
MOGGRIDGE, Bill. Designing Interactions. London, England. MIT Press: 2006.

MONK, Andrew; WRIGHT, Peter; HABER, Jeanne; DAVENPORT, Lora. Improving your Human-Computer Interface. Pentice Hall: 1993.

MORAES, Anamaria. Design e Avaliação de Interface: ergodesign e interação humano computador. Organizadora: Anamaria de Moraes. Rio de Janeiro: iUsEr, 2002.

MURRAY, Janet. Hamlet no Holodeck: o futuro da narrativa no Ciberespaço. SP: Itaú Cultural-UNESP, 2003.

OLIVEIRA, M. A. Leitura prazer: interação participativa com a literatura infantil na escola. São Paulo: Paulinas, 1996.

PAVANI, Cecília; PARENTE, Cristiane; ORMANEZE, Fabiano (Orgs.). Educomunicação, redes sociais e interatividades. Campinas, SP: Edições Leitura Crítica, 2013.

PORTUGAL, Cristina. Design, Educação e Tecnologia. Rio de Janeiro: Rio Books. 1a edição 2013. 148p.

PORTUGAL, Cristina. Design como interface de comunicação para ambientes de aprendizado mediados pela internet. Dissertação (Mestrado em Design). Departamento de Artes \& Design. Pontifícia Universidade Católica do Rio de Janeiro, Rio de Janeiro, 2004.

PORTUGAL, Cristina. Design em Situações de Ensino-aprendizagem. Um Dialogo Interdisciplinar. 2009. 206p. Tese (Doutorado em Design), Departamento de Artes e Design. Pontifícia Universidade do Rio de Janeiro, Rio de Janeiro, 2009.

PORTUGAL, Cristina, JORDY, Eliane; CORREIA, Ana Tereza. Design and interactive bilingual literature. In: Souto, V. T.; Spinillo C. G.; Portugal, C.; Fadel, L. M. (Org.). Selected Readings of the 7th Information Design International Conference. 1ed. Brasília: Sociedade Brasileira de Design da Informação, 2016, v. 1, p. 51-63.

PORTUGAL, Cristina; JORDY. Eliane; CORREIA, Ana Tereza, COUTO, Rita Maria de Souza; ALRAN, Felipe. Design and Narrative for Deaf and Listener Children. In: Kia Ng; Jonathan P. Blowen; Nick Lambert. (Org.). EVA LONDON 2015 Electronic Visualization and the Arts. 1ed.London: BCS Learnin \& Development Ltd, 2015, v. , p. 100-110.

PORTUGAL, Cristina. et al. Design in the creation of an interactive e-book for deaf and listening Children. In: THE VALUE OF DESIGN RESEARCH. 11th International European Academy of Design Conference,. Paris: Paris Descartes University.

PRESTES, Zoia. Quando não é quase a mesma coisa: análise e traduções de Lev Semionovich no Brasil. Repercussões no campo educacional. Brasília, 2010. 295 p. Tese de Pós-Graduação em Educação da Faculdade de Educação da Universidade de Brasília/UnB. 
QUADROS, Ronice Muller. Educação de Surdos: aquisição da linguagem. Porto Alegre, RS. Artes Médicas: 1997

RYAN, Marie-Laure. Narrative across Media: The Languages of Storytelling (Frontiers of Narrative- 2nd edition). Boston: Elsevirer - Focal Press, 2008.

SACKS, Oliver W. Vendo Vozes: uma viagem ao mundo dos surdos. São Paulo. Companhia das Letras: 1998.

SANTAELLA, Lucia. Comunicação ubíquo: repercussões na cultura e na educação. São Paulo: Paulus, 2013. -(Coleção comunicação)

SAYAD, Alexandre Le Voci. Idade Mídia: A comunicação reinventada na escola. São Paulo: Aleph, 2011.

SCHÖN, Donald. A Educando o profissional reflexivo: um novo design para o ensino e aprendizagem. Porto Alegre, Artmed, 2000

SHARP, Helen; Rogers, Yvonne; Preece, Jenny (2007). Interaction Design: Beyond Human-Computer Interaction (2nd ed.). John Wiley \& Sons. pp. 181-217 [184].

TEIXEIRA, D. e; et al.; A sintaxe visual no design de interface do book app infantil treasure kai and the lost gold shark island, p. 79-91 . In: Anais do $11^{\circ}$ Congresso Brasileiro de Pesquisa e Desenvolvimento em Design. v. 1, n. 4]. São Paulo: Blucher, 2014.

VYGOTSKY, Lev Semyonovich. Pensamento e Linguagem. 4 ${ }^{\mathrm{a}}$ Ed. - São Paulo: Martins Fontes, 2008.

VYGOTSKY, Lev Semyonovich. "Pensamento e Palavra" In A Construção do Pensamento e da Linguagem; tradução Paulo Bezerra 2ª Ed. - São Paulo: Editora WMF Martins Fontes, 2009.

VYGOTSKY, Lev Semyonovich. A Formação Social da Mente: o desenvolvimento dos processos psicológicos superiores.

Organizadores Michel Cole.; tradução José Cipolla Neto, Luís Silveira Menna Barreto, Solange Castro Afeche. 6 ${ }^{\mathrm{a}}$ Ed. - São Paulo: Martins Fontes, 1998.

VYGOTSKY, Lev Semyonovich.. Imaginação e Criação na Infância: ensaio psicológico; apresentação e comentários Ana Luiza Smolka; tradução Zoia Prestes.- São Paulo: Ática, 2009.

XAVIER, Antonio Carlos. A Era do Hipertexto. Linguagem e Tecnologia. Recife: Editora Universitária UFPE, 2009. 